Shallow Coal Exploration Drill-Hole Data-Alabama, Georgia, Kentucky, Louisiana, Mississippi, Missouri, North Carolina, South Carolina, Tennessee, and Texas

Open-File Report 2011-1261 


\section{Shallow Coal Exploration Drill-Hole Data-Alabama, Georgia, Kentucky, Louisiana, Mississippi, Missouri, North Carolina, South Carolina, Tennessee, and Texas}

Edited by Brett J. Valentine and Kristin 0. Dennen

Open-File Report 2011-1261 


\section{U.S. Department of the Interior \\ KEN SALAZAR, Secretary \\ U.S. Geological Survey \\ Marcia K. McNutt, Director}

\section{U.S. Geological Survey, Reston, Virginia: 2012}

For more information on the USGS - the Federal source for science about the Earth, its natural and living resources, natural hazards, and the environment, visit http://www.usgs.gov or call 1-888-ASK-USGS.

For an overview of USGS information products, including maps, imagery, and publications, visit http://www.usgs.gov/pubprod

To order this and other USGS information products, visit http://store.usgs.gov

Any use of trade, product, or firm names is for descriptive purposes only and does not imply endorsement by the U.S. Government.

Although this report is in the public domain, permission must be secured from the individual copyright owners to reproduce any copyrighted materials contained within this report.

Suggested citation:

Valentine, B.J., and Dennen, K.O., eds., 2012, Shallow coal exploration drill-hole data—Alabama, Georgia, Kentucky, Louisiana,

Mississippi, Missouri, North Carolina, South Carolina, Tennessee, and Texas: U.S. Geological Survey Open-File Report 2011-1261, 102 p. 


\section{Contents}

A. Overview of Shallow Coal Exploration Drill-Hole Data- Alabama, Georgia, Kentucky, Louisiana, Mississippi, Missouri, North Carolina, South Carolina, Tennessee, and Texas

B. Shallow Coal Exploration Drill-Hole Data, Alabama

C. Shallow Coal Exploration Drill-Hole Data, Georgia

D. Shallow Coal Exploration Drill-Hole Data, Western Kentucky

E. Shallow Coal Exploration Drill-Hole Data, Northern Louisiana

F. Shallow Coal Exploration Drill-Hole Data, Mississippi

G. Shallow Coal Exploration Drill-Hole Data, Southeastern Missouri

H. Shallow Coal and Kaolinite Exploration Drill-Hole Data, North Carolina and South Carolina

I. Shallow Coal Exploration Drill-Hole Data, Western Tennessee

J. Shallow Coal Exploration Drill-Hole Data, Northeast Texas

K. Shallow Coal Exploration Drill-Hole Data, South and East-Central Texas 


\section{Overview of Shallow Coal Exploration Drill-Hole Data-Alabama, Georgia, Kentucky, Louisiana, Mississippi, Missouri, North Carolina, South Carolina, Tennessee, and Texas}

By Matthew D. Merrill, Brett J. Valentine, and Kristin 0. Dennen

\section{Chapter A of}

Shallow Coal Exploration Drill-Hole Data-Alabama, Georgia, Kentucky, Louisiana, Mississippi, Missouri, North Carolina, South Carolina, Tennessee, and Texas

Edited by Brett J. Valentine and Kristin O. Dennen

Open-File Report 2011-1261-A 
Suggested citation:

Merrill, M.D, Valentine, B.J., and Dennen, K.0., 2012, Overview of shallow coal exploration drill-hole dataAlabama, Georgia, Kentucky, Louisiana, Mississippi, Missouri, North Carolina, South Carolina, Tennessee, and Texas, in Valentine, B.J., and Dennen, K.O., eds., Shallow coal exploration drill-hole data—Alabama, Georgia, Kentucky, Louisiana, Mississippi, Missouri, North Carolina, South Carolina, Tennessee, and Texas: U.S. Geological Survey Open-File Report 2011-1261, ch. A, 6 p. plus appendix. (Available online.) 


\section{Contents}

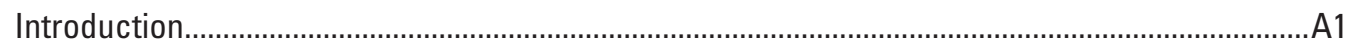

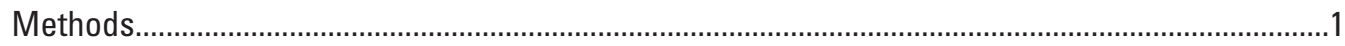

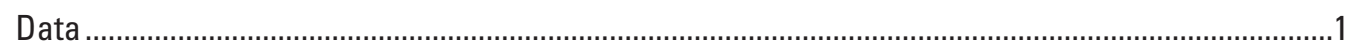

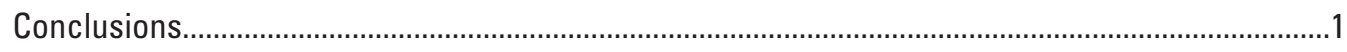

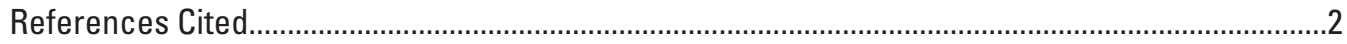

Appendix A. The North American Coal Corporation letter describing confidentiality

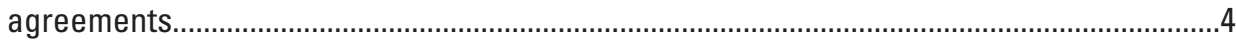

\section{Figures}

A1. Regional map showing drill-hole locations .................................................................A2

A2. Generalized stratigraphic chart showing major and minor coal-bearing formations in the Mississippi Embayment and Gulf Coast Plain...... 


\title{
Overview of Shallow Coal Exploration Drill-Hole Data- Alabama, Georgia, Kentucky, Louisiana, Mississippi, Missouri, North Carolina, South Carolina, Tennessee, and Texas
}

\author{
By Matthew D. Merrill, Brett J. Valentine, and Kristin 0. Dennen
}

\section{Introduction}

Coal exploration drill-hole data from over 24,000 wells in 10 States are discussed by State in the chapters of this report, and the data are provided in an accompanying spreadsheet. The drill holes were drilled between 1962 and 1984 by Phillips Coal Company, a division of Phillips Petroleum Company (Phillips). The data were donated to the U.S. Geological Survey (USGS) in 2001 by the North American Coal Corporation, which purchased the Phillips assets as part of a larger dataset. Under the terms of the agreement with North American Coal Corporation, the data were deemed proprietary until February 2011, a period of 10 years after the donation (Appendix). Now that the required period of confidentiality has passed, the data have been digitized from tabulated data files to create unified and spatially consistent coal exploration drill-hole maps and reports for the States of Alabama, Georgia, Kentucky, Louisiana, Mississippi, Missouri, North Carolina, South Carolina, Tennessee, and Texas. The data are made publically available by this report.

\section{Methods}

Annotated topographic field and county highway maps from Phillips, generally at 1:62,500 to 1:100,000 scale, were utilized to generate the drill-hole datasets. The drill-hole locations in State coordinate plane projections were digitized from hardcopy maps into a geographic information system using ArcMap ${ }^{\mathrm{TM}}$ software from the Environmental Systems Research Institute, Inc. (ESRI). Fiducial marks and county boundaries served as reference points. Maps were scanned and georeferenced; drill-hole locations were digitized and shapefile attribute values were populated with data from the maps. The maps and data were then reprojected into a North American Datum of 1983 geographic coordinate system.

\section{Data}

The data provide locally dense drill-hole coverage (fig. A1) for the Gulf of Mexico coal region, the southern part of the Appalachian coal region, and North and South Carolina. A regional stratigraphic chart with major and minor coal-bearing formations in the Gulf of Mexico coal region is shown in figure A2. Each of the 10 State reports (chapters $\mathrm{B}-\mathrm{K}$, this volume) has a map of the State with drill-hole coverage that includes drill holes where coal was found and drill holes where there was no coal. In addition, a list of counties is included in each State report with the number of drill holes for each county, and an appendix in each State report directs the reader to a spreadsheet with tabulated coal thickness data. When available, electric log probe depths and indications of core sampling are also included in the tabulated data. The coal thickness data from the State reports have been uploaded to the USGS National Coal Resources Data System UStratigraphic (USTRAT) database, part of the National Coal Resources Data System (NCRDS) at energy.usgs.gov/Tools/ NationalCoalResourcesDataSystem.aspx.

\section{Conclusions}

The data provided in the State reports (chapters B-K) compliment NCRDS State shallow coal resources data because the data include both coal and "no-coal" drill-hole information, whereas the NCRDS accepts only coal thickness data points. The coal thickness data in the spreadsheet(s) that accompany each report reflect corrections for duplicates, mislabeling, and incorrect locations identified by the computer programs used to upload the data to NCRDS. For the States of North and South Carolina, the reports include "no-kaolinite" drill-hole locations as well as "no-coal" drill-hole locations because kaolinite is an economic resource in these States. 


\section{References Cited}

Ogg, J.G., Ogg, Gabi, and Gradstein, F.M., 2008, The concise geologic time scale: Cambridge, U.K., Cambridge University Press, 184 p.

Warwick, P.D., SanFilipo, J.R., Crowley, S.S., Thomas, R.E., and Freid, J., comps., and Tully, J.K., digital comp., 1997, Map showing outcrop of the coal-bearing units and land use in the Gulf Coast coal region: U.S. Geological Survey Open-File Report 97-172, 1 sheet, accessed April 20, 2011, at pubs.usgs.gov/of/1997/of97-172/.

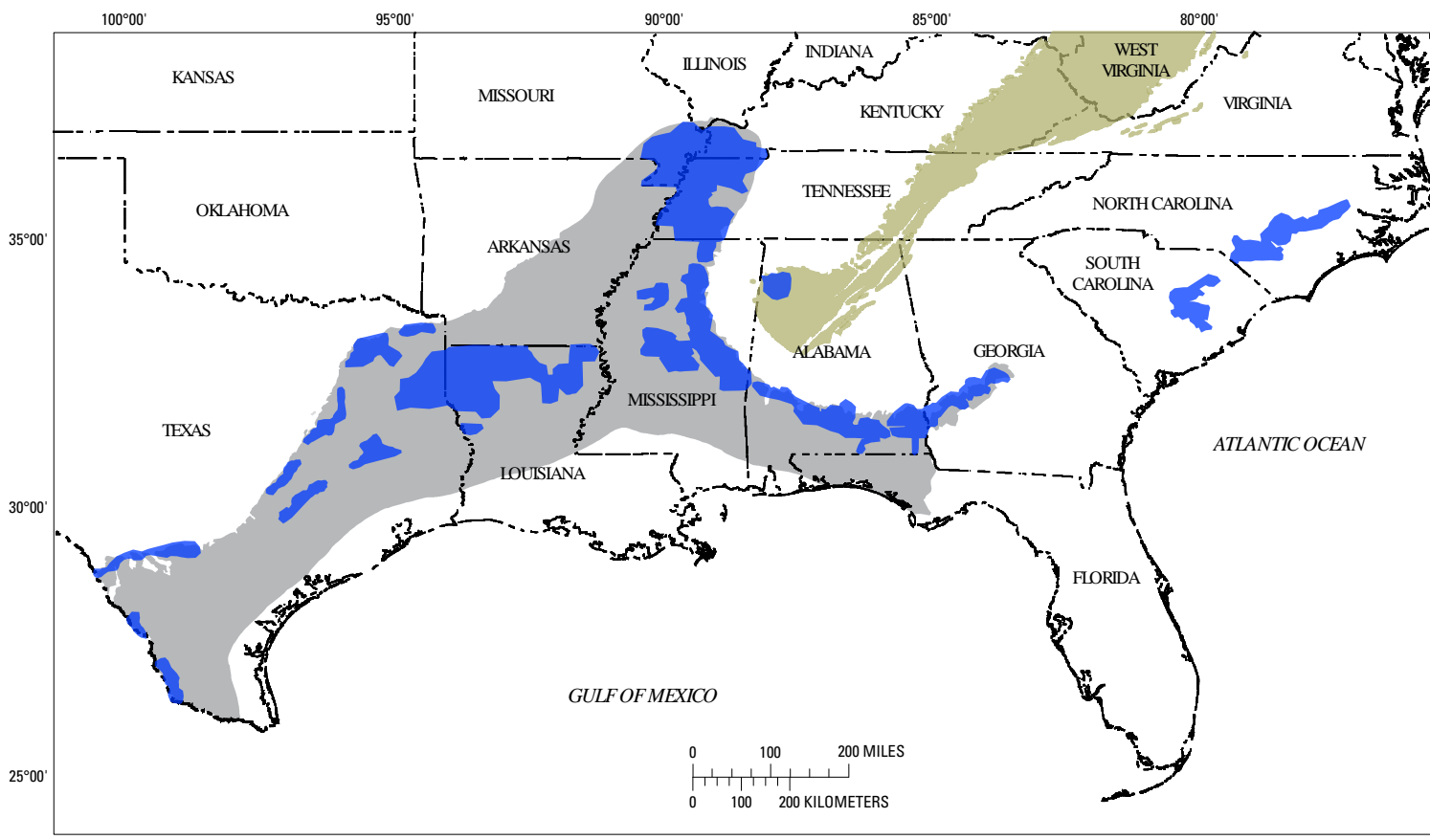

EXPLANATION

Gulf Coast Coal Region Appalachian Coal Region State boundary Areas where drill holes arelocated

Figure A1. Regional map showing drill-hole locations. 


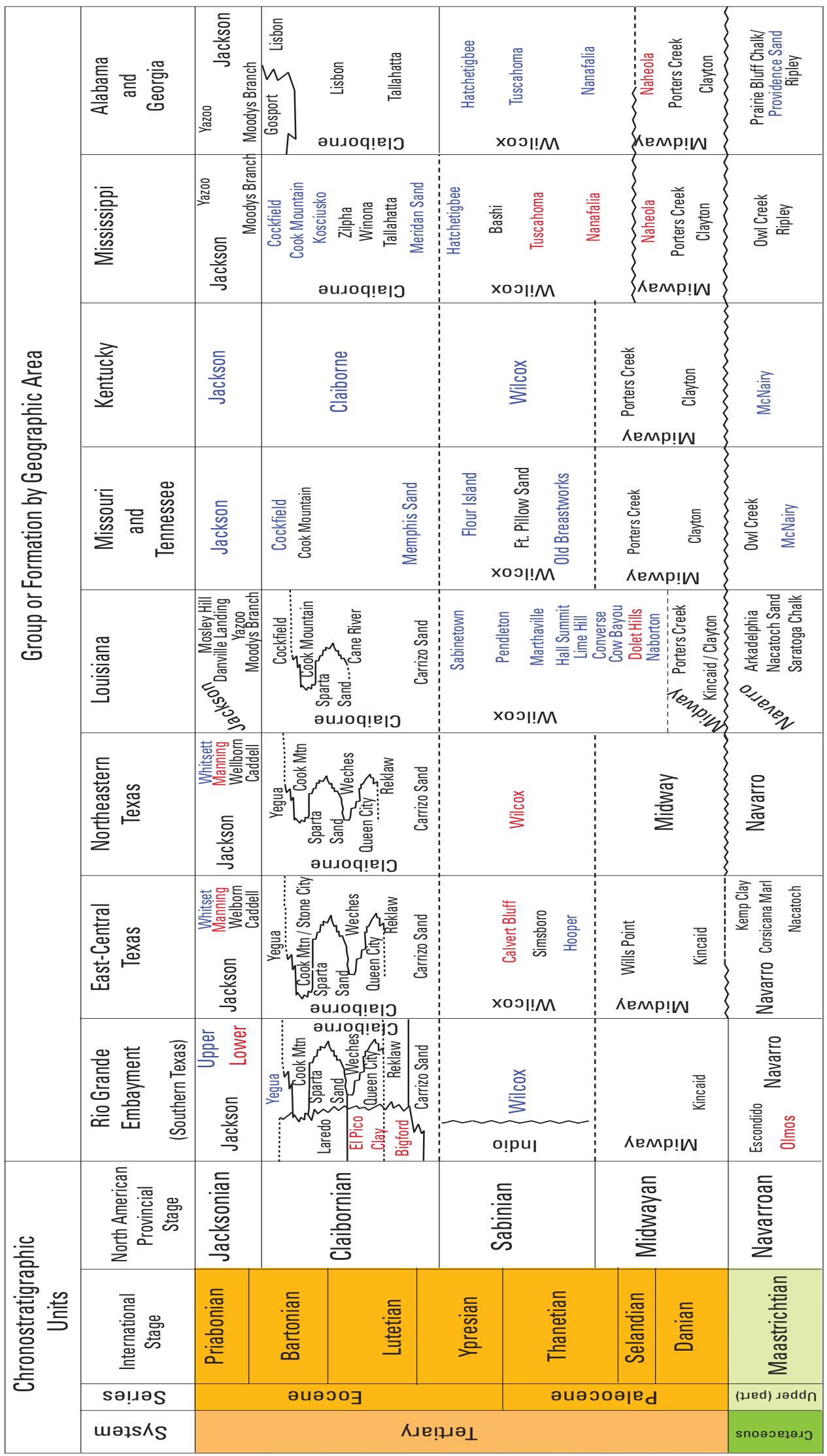




\section{Appendix A. The North American Coal Corporation letter describing confidentiality agreements.}

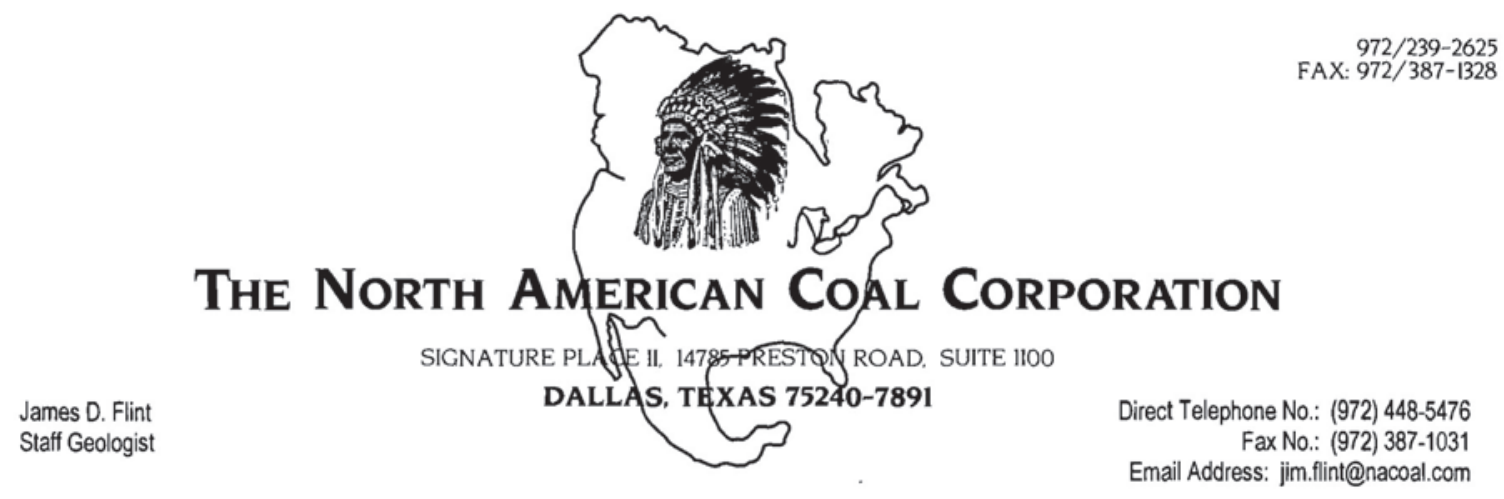

February 14, 2001

Mr. Peter Warwick

Geologist

United States Geological Survey

956 National Center

Reston, VA 20192

Dear Mr. Warwick:

We are hereby transmitting to the United States Geological Survey various coal related information for use in the National Coal Resource Data System. The information is stored in 59 file boxes and 81 map boxes.

The information concerns the following states:

$\begin{array}{lll}\text { Alaska } & \text { Kentucky } & \text { Oklahoma } \\ \text { Alabama } & \text { Louisiana } & \text { Oregon } \\ \text { Arkansas } & \text { Maryland } & \text { Rhode Island } \\ \text { Arizona } & \text { Maine } & \text { South Carolina } \\ \text { California } & \text { Michigan } & \text { South Dakota } \\ \text { Colorado } & \text { Missouri } & \text { Tennessee } \\ \text { Florida } & \text { Mississippi } & \text { Texas } \\ \text { Georgia } & \text { Montana } & \text { Utah } \\ \text { lowa } & \text { North Carolina } & \text { Washington } \\ \text { Idaho } & \text { North Dakota } & \text { West Virginia } \\ \text { Illinois } & \text { Nebraska } & \text { Wyoming } \\ \text { Indiana } & \text { New Jersey } & \text { Virginia } \\ \text { Kansas } & \text { New Mexico } & \end{array}$

There is also information concerning Puerto Rico, Trinidad, Canada, and South America.

We would like this information to be held as proprietary for a period of ten years, as shown by the attached sheet. 
A photocopy of a computer printout showing an inventory of the map boxes is enclosed. The items highlighted in pink have been removed and are not included in this transmittal. We do not have an inventory of the file boxes.

Please call me if you have any questions.

Sincerely,

THE NORTH AMERICAN COAL CORPORATION

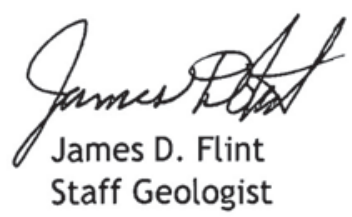

$$
\begin{aligned}
& \text { JDF:Irh } \\
& \text { Enclosure } \\
& \begin{array}{ll}
\text { cC: } \quad \text { T. D. Aderman ( } w / 0 \text { enclosures) } \\
\text { T. A. Koza ( } w / 0 \text { enclosures) } \\
\text { C. A. Moseley (w/o enclosures) }
\end{array}
\end{aligned}
$$




\section{CLASSIFICATION OF USGS NCRDS STRATIGRAPHIC DATA}

I. Public Domain - All data and point locality can be released to anyone.

II. Pending Validation - Data that will become either Public Domain or Proprietary upon validation. These data are available for inspection and use by USGS and State Survey personnel under confidentiality agreements.

III. Proprietary - Company Confidential data and/or locality have been provided by a Private Company and written agreements as to access of the data are on record. These data are available for inspection and use by USGS and State Survey personnel under confidentiality agreements.

1. Definite Release - Data and locality will be released after 10 years.

2. Indefinite Release - Data can be used under the following restrictions by authorized USGS, Federal, or State Agency users:
a. Locality shown as a point only, without attribution or identification.
b. Locality shown as mine name only.
c. Locality not revealed in any form; data are used for compilations or interpretive map production.




\section{Shallow Coal Exploration Drill-Hole Data, Alabama}

By Matthew D. Merrill, Peter D. Warwick, and Christopher R. Burr

Chapter B of

Shallow Coal Exploration Drill-Hole Data-Alabama, Georgia, Kentucky, Louisiana, Mississippi, Missouri, North Carolina, South Carolina, Tennessee, and Texas

Edited by Brett J. Valentine and Kristin O. Dennen

Open-File Report 2011-1261-B 
Suggested citation:

Merrill, M.D., Warwick, P.D., and Burr, C.R., 2012, Shallow coal exploration drill-hole data, Alabama, in Valentine, B.J., and Dennen, K.O., eds., Shallow coal exploration drill-hole data-Alabama, Georgia, Kentucky, Louisiana, Mississippi, Missouri, North Carolina, South Carolina, Tennessee, and Texas: U.S. Geological Survey Open-File Report 2011-1261, ch. B, 5 p. plus appendix. (Available online.) 


\section{Contents}

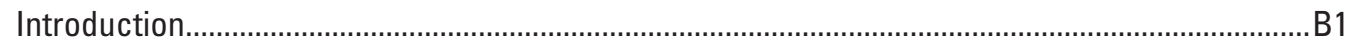

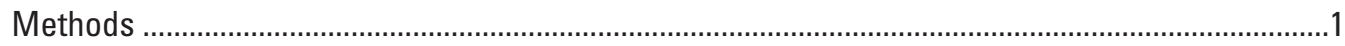

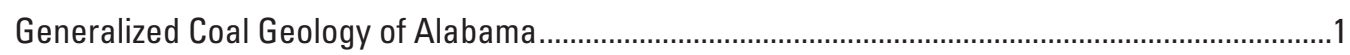

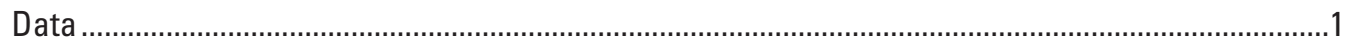

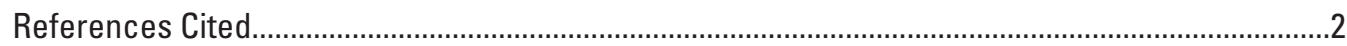

Appendix B1. Shallow Coal Exploration Drill-Hole Data for Alabama ................................................2

\section{Figures}

B1. Map of Alabama showing locations of areas with drill holes..........................................B4

B2. Generalized stratigraphic chart showing major and minor coal-bearing formations in the Mississippi Embayment and Gulf Coastal Plain .....

\section{Tables}

B1. Attribute titles and data descriptions and formats for the Alabama coal exploration drill-hole dataset.

B2. Explanation of comments used to describe the Alabama drill-hole dataset.....................3

B3. Alabama counties and the number of drill holes by county. ............................................ 


\title{
Shallow Coal Exploration Drill-Hole Data, Alabama
}

\author{
By Matthew D. Merrill, Peter D. Warwick, and Christopher R. Burr
}

\section{Introduction}

Coal exploration drill-hole data from 2,520 wells drilled in Alabama between 1977 and 1979 by Phillips Coal Company, a division of Phillips Petroleum Company (Phillips), are discussed in this chapter, and the data are provided in an accompanying spreadsheet. The data are part of a larger dataset donated to the U.S. Geological Survey by the North American Coal Corporation, which purchased Phillips assets in 2001 (see chapter A, this volume). The data in 10 State reports have been digitized from field maps to create unified and spatially consistent coal exploration drill-hole datasets for each of the States (chapters B-K, this volume). Data for Alabama include a map of the State showing areas with drill-hole coverage (fig. B1), a list of data attributes and explanations of the data format (table B1), a list of comments found in the data and descriptions of them (table B2), a list of counties and the number of drill holes for each county (table B3), and tabulated data in spreadsheet format (see appendix B1).

\section{Methods}

Annotated topographic field and county highway maps from Phillips, generally at 1:62,500 to 1:100,000 scale, were utilized to generate the drill-hole datasets. Alabama State coordinate plane projection source material from 1927 was digitized from hardcopy maps into a geographic information system using ArcMap ${ }^{\mathrm{TM}}$ software from the Environmental Systems Research Institute, Inc. (ESRI). Fiducial marks and county boundaries served as reference points. Maps were scanned and georeferenced; drill-hole locations were digitized and shapefile attribute values were populated with data from the maps. To facilitate combining this dataset with datasets for other States, the dataset has been projected into a North American Datum of 1983 geographic coordinate system. The shapefile data were exported to a spreadsheet (appendix B1).

\section{Generalized Coal Geology of Alabama}

The Eocene/Paleocene Wilcox Group is a coal-bearing unit in southern Alabama (Warwick and others, 1997) (fig. B2). Coal-bearing formations in the Wilcox include the Nanafalia, Tuscahoma Sand, and Hatchetigbee. The coal-bearing formation of the Paleocene Midway Group is the Naheola Formation (Warwick and others, 1997). The Pennsylvanian age Upper Pottsville Formation is a shallow coal-bearing unit in the Warrior Basin in northwestern Alabama (Hatch and Pawlewicz, 2007).

\section{Data}

The Alabama data provide drill-hole coverage in southern Alabama from the west to the east of the State as well as drill-hole coverage in northwestern Alabama (figs. B1, B2). Probed depth data for 1,867 drill holes range from 17 to 395 feet with a mean depth of 205 feet. The discrepancy between the 2,520 total holes in this dataset and the 1,867 cited above reflects holes that were planned and mapped but may not have been drilled. Location error, due to the reduced resolution and generalized nature of highway maps, is expected to be \pm 0.25 miles. Shapefile attributes include all original raw data from the Phillips drill-hole location maps (table B1). 


\section{References Cited}

Gesch, D., Oimoen, M., Greenlee, S., Nelson, C., Steuck, M., and Tyler, D., 2002, The National Elevation Dataset: Photogrammetric Engineering and Remote Sensing, v. 68, no. 1 , p. 5-11.

Hatch, J.R., and Pawlewicz, M.J., 2007, Petroleum assessment of the Pottsville Coal Total Petroleum System, Black Warrior Basin, Alabama and Mississippi, in Hatch, J.R., and Pawlewicz, M.J., comps., Geologic assessment of undiscovered oil and gas resources of the Black Warrior Basin Province, Alabama and Mississippi: U.S. Geological Survey Digital Data Series DDS-69-I, ch. 4, 28 p., accessed August 31, 2011, at pubs.usgs.gov/dds/dds-069/dds-069-i/ REPORTS/69_I_CH_4.pdf.
Ogg, J.G., Ogg, Gabi, and Gradstein, F.M., 2008, The concise geologic time scale: Cambridge, U.K., Cambridge University Press, 184 p.

Warwick, P.D., SanFilipo, J.R., Crowley, S.S., Thomas, R.E., and Freid, J., comps., and Tully, J.K., (digital comp., 1997, Map showing outcrop of the coal-bearing units and land use in the Gulf Coast coal region: U.S. Geological Survey Open-File Report 97-172, 1 sheet, accessed April 20, 2011, at pubs.usgs.gov/of/1997/of97-172/.

\section{Appendix B1}

The Alabama coal exploration drill-hole dataset in spreadsheet format is available at pubs.usgs.gov/of/2011/1261/ Appendices/B1-AL.xls.

Table B1. Attribute titles and data descriptions and formats for the Alabama coal exploration drill-hole dataset.

\begin{tabular}{ll}
\hline \multicolumn{1}{c}{ Attribute title } & \multicolumn{1}{c}{ Data description and format } \\
\hline DRILL-HOLE NAME & Two-letter county code followed by drill-hole number. \\
COUNTY & County where the drill hole is located. \\
ELEVATION & Elevation above sea level in feet. \\
DEPTH_TOTAL & Depth of drill hole in feet. \\
DEPTH_PROBED & Depth of geophysical probe measurement in feet. \\
LATITUDE & Decimal degree location values given to 4 decimal places. \\
LONGITUDE & Decimal degree location values given to 4 decimal places. \\
X_C & Thickness of coal for bed number X in decimal feet. \\
X_CP & Thickness of coal and partings combined for bed number X in decimal feet. \\
X_DEPTH & Top depth of bed number X in feet. \\
COMMENT & Additional information regarding the drill hole. See table B2 for an explanation of comments. \\
\hline
\end{tabular}


Table B2. Explanation of comments used to describe the Alabama drill-hole dataset (J.A. Luppens, U.S. Geological Survey, written commun., 2009).

\begin{tabular}{ll}
\hline \multicolumn{1}{c}{ Comment } & \multicolumn{1}{c}{ Description } \\
\hline ? & There is uncertainty about the drill hole. \\
Carbonaceous; CM & Coal has a high ash content. \\
Data Depth & Minimum depth as determined by the deepest coal depth and thickness when well depth is not available. \\
DEM & Elevation of the drill-hole determined by a digital elevation model (Gesch, 2002). \\
Inferior Lignite & Lignite found in the drill hole was of poor quality. \\
Lignite & Lignite was found in the drill hole. \\
NC & Abbreviation for "no coal.” No coal was found during exploration for this drill-hole. \\
NP & Abbreviation for "Not probed.” Geophysical logging never occurred at this location. \\
NSL & Abbreviation for "No significant lignite." Coal may have been found during exploration but because the \\
& coal beds were thin (usually less than 2 ft. thick) no coal data was recorded. \\
Partially Inferior Lignite & Lignite found in the drill hole was of poor quality. \\
Poor Lignite & Lignite found in the drill hole was of poor quality. \\
Trace Lignite & The drill hole contained only traces of lignite. \\
Visual Estimate & Depth to top of coal bed estimated visually—not measured. \\
\hline
\end{tabular}

Table B3. Alabama counties and the number of drill holes by county.

\begin{tabular}{|c|c|}
\hline County & Number of drill holes \\
\hline Barbour & 493 \\
\hline Butler & 331 \\
\hline Choctaw & 98 \\
\hline Coffee & 176 \\
\hline Conecuh & 53 \\
\hline Covington & 82 \\
\hline Crenshaw & 209 \\
\hline Dale & 174 \\
\hline Franklin & 10 \\
\hline Henry & 388 \\
\hline Houston & 19 \\
\hline Lamar & 7 \\
\hline Lowndes & 1 \\
\hline Marengo & 135 \\
\hline Marion & 135 \\
\hline Monroe & 143 \\
\hline Pike & 3 \\
\hline Sumter & 5 \\
\hline Wilcox & 58 \\
\hline Total & 2,520 \\
\hline
\end{tabular}




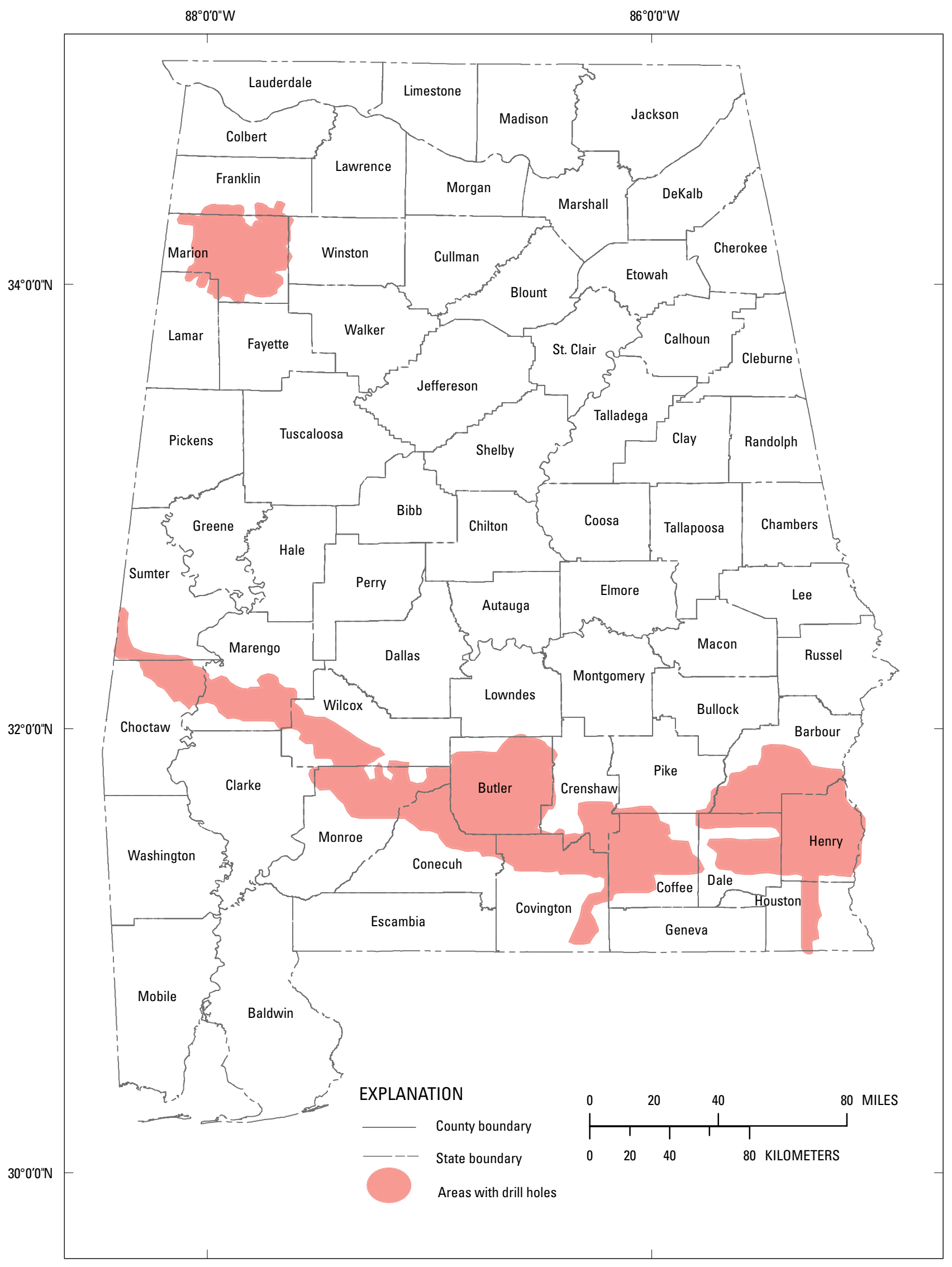

Figure B1. Map of Alabama showing locations of areas with drill holes. 

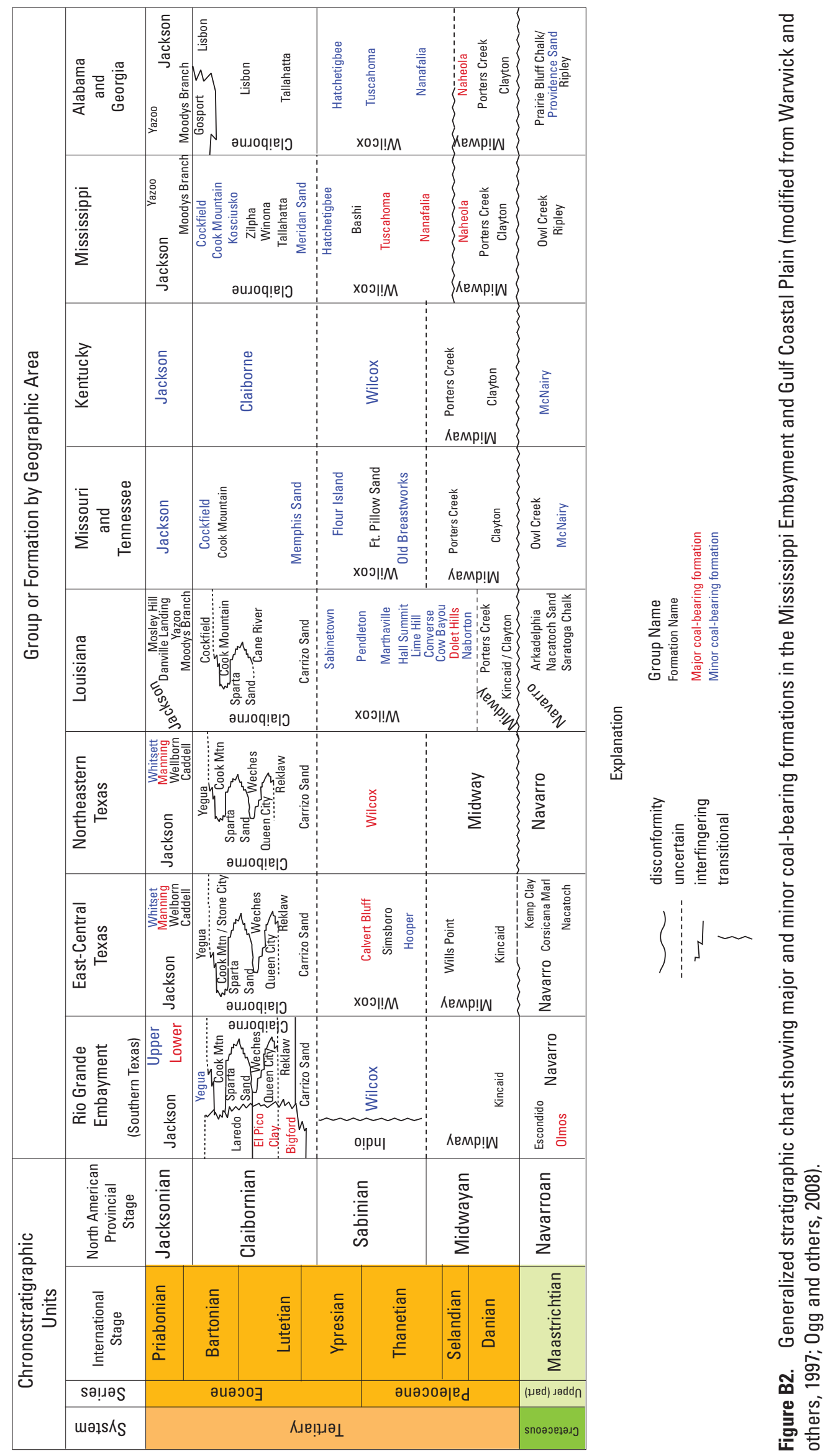


\section{Shallow Coal Exploration Drill-Hole Data, Georgia}

By Matthew D. Merrill and Peter D. Warwick

Chapter $\mathrm{C}$ of

Shallow Coal Exploration Drill-Hole Data-Alabama, Georgia, Kentucky, Louisiana, Mississippi, Missouri, North Carolina, South Carolina, Tennessee, and Texas

Edited by Brett J. Valentine and Kristin O. Dennen

Open-File Report 2011-1261-C 
Suggested citation:

Merrill, M.D., and Warwick, P.D., 2012, Shallow coal exploration drill-hole data, Georgia, in Valentine, B.J., and

Dennen, K.O., eds., Shallow coal exploration drill-hole data—Alabama, Georgia, Kentucky, Louisiana, Mississippi, Missouri, North Carolina, South Carolina, Tennessee, and Texas: U.S. Geological Survey Open-File Report 2011-1261, ch. C, 5 p. plus appendix. (Available online.) 


\section{Contents}

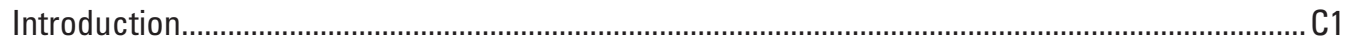

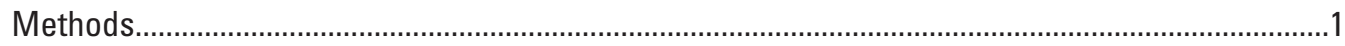

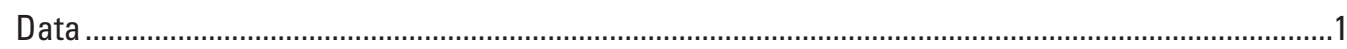

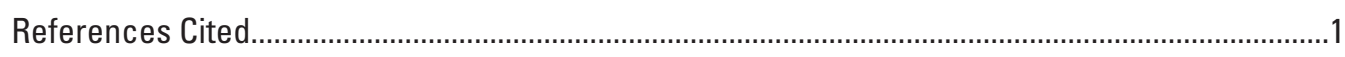

Appendix C1. Shallow Coal Exploration Drill-Hole Data for Georgia ...............................................1

\section{Figures}

C1. Map of Georgia showing locations of areas with drill holes ........................................ C4

C2. Generalized stratigraphic chart showing major and minor coal-bearing formations in the Mississippi Embayment and Gulf Coastal Plain

\section{Tables}

C1. Attribute titles and data descriptions and formats for the Georgia coal exploration drill-hole dataset......

C2. Explanation of comments used to describe the Georgia drill-hole dataset. ......................2

C3. Georgia counties and the number of drill holes by county.............................................. 


\title{
Shallow Coal Exploration Drill-Hole Data, Georgia
}

\author{
By Matthew D. Merrill and Peter D. Warwick
}

\section{Introduction}

Coal exploration drill-hole data from 746 wells drilled in Georgia between April and November of 1978 by Phillips Coal Company, a division of Phillips Petroleum Company (Phillips), are discussed in this chapter, and the data are provided in an accompanying spreadsheet. The data are part of a larger dataset donated to the U.S. Geological Survey by the North American Coal Corporation, which purchased Phillips assets in 2001 (see chapter A, this volume). The data in 10 State reports have been digitized from field maps to create unified and spatially consistent coal exploration drill-hole datasets for each of the States (chapters B-K, this volume). Data for Georgia include a map of the State showing areas with drill-hole coverage (fig. C1), a list of data attributes and explanations of the data format (table C1), a list of comments found in the data and descriptions of them (table C2), a list of counties and the number of drill holes for each county (table C3), and tabulated data in spreadsheet format (see appendix C1).

\section{Methods}

Annotated topographic field and county highway maps from Phillips, generally at 1:62,500 to 1:100,000 scale, were utilized to generate the drill-hole datasets. Georgia State coordinate plane projection source material from 1927 was digitized from hardcopy maps into a geographic information system using ArcMap ${ }^{\mathrm{TM}}$ software from the Environmental Systems Research Institute, Inc. (ESRI). Fiducial marks and county boundaries served as reference points. Maps were scanned and georeferenced, drill-hole locations were digitized, and shapefile attribute values were populated with data from the maps. To facilitate combining this dataset with datasets for other States, the dataset has been reprojected into a North American Datum of 1983 geographic coordinate system. The shapefile was exported to a spreadsheet (see appendix C1).

\section{Data}

The Georgia data provide drill-hole coverage for southwestern Georgia (fig. C1). Drill-hole depths range from 30 to 300 feet with an average depth of 237 feet. For a stratigraphic chart of coal-bearing formations in Georgia, see figure C2. Location error, if present, is the result of those completing the data sheets. The transcription process involved no map digitization; therefore, there are no spatial errors associated with the creation of this dataset. Comparisons between digitized highway map points and their corresponding drillhole tabulation sheet coordinates indicate that the drilling team accurately determined their locations from local topographic maps. Shapefile attributes include all original raw data with the exception of the landowner information (table C1).

\section{References Cited}

Ogg, J.G., Ogg, Gabi, and Gradstein, F.M., 2008, The concise geologic time scale: Cambridge, U.K., Cambridge University Press, 184 p.

Warwick, P.D., SanFilipo, J.R., Crowley, S.S., Thomas, R.E., and Freid, J., comps., and Tully, J.K., digital comp., 1997, Map showing outcrop of the coal-bearing units and land use in the Gulf Coast coal region: U.S. Geological Survey Open-File Report 97-172, 1 sheet, accessed April 20, 2011, at pubs.usgs.gov/of/1997/of97-172/.

\section{Appendix C1}

The Georgia coal exploration drill-hole dataset in spreadsheet format is available at pubs.usgs.gov/of/2011/1261/ Appendices/C1-GA.xls. 
Table C1. Attribute titles and data descriptions and formats for the Georgia coal exploration drill-hole dataset.

\begin{tabular}{ll}
\hline \multicolumn{1}{c}{ Attribute title } & \multicolumn{1}{c}{ Data description and format } \\
\hline DRILL-HOLE NAME & Two-letter county code followed by drill-hole number. \\
COUNTY & County where the drill hole is located. \\
ELEVATION & Elevation above sea level in feet. \\
DEPTH_TOTAL & Depth of drill hole in feet. \\
DEPTH_PROBED & Depth of geophysical probe measurement in feet. \\
LATITUDE & Decimal degree location values given to 4 decimal places. \\
LONGITUDE & Decimal degree location values given to 4 decimal places. \\
X_C & Thickness of coal for bed number $\mathrm{X}$ in decimal feet. \\
X_CP & Thickness of coal and partings combined for bed number $\mathrm{X}$ in decimal feet. \\
COMMENT & Additional information regarding the drill hole. See table C2 for an explanation of comments. \\
\hline
\end{tabular}

Table C2. Explanation of comments used to describe the Georgia drill-hole dataset (J.A. Luppens, U.S. Geological Survey, written commun., 2009).

\begin{tabular}{ll}
\hline \multicolumn{1}{c}{ Symbol/Comment } & \multicolumn{1}{c}{ Description } \\
\hline$?$ & Questionable data/information. \\
Inferior & Subjective term used to describe low-quality coal. \\
Inferior Lignite & Subjective term used to describe low-quality lignite. \\
Lignite & A low-ranking coal was found during exploration. \\
NC & Abbreviation for "no coal.” No coal was found during exploration for this drill hole. \\
No Data & No data was recorded on the original coal exploration maps for this drill hole. \\
NP & Abbreviation for "not probed.” Geophysical logging never occurred at this location. \\
NSL & Abbreviation for "no significant lignite." Coal may have been found during exploration but because the \\
& coal beds were thin (usually less than 2 feet thick) no coal data was recorded. \\
Partially Inferior Lignite & Used to describe that a portion of the coal bed is of a low quality. \\
\hline
\end{tabular}


Table C3. Georgia counties and the number of drill holes by county.

\begin{tabular}{|c|c|}
\hline County & Number of drill holes \\
\hline Clay & 195 \\
\hline Dooly & 7 \\
\hline Houston & 37 \\
\hline Macon & 77 \\
\hline Marion & 1 \\
\hline Peach & 16 \\
\hline Quitman & 133 \\
\hline Randolph & 67 \\
\hline Schley & 40 \\
\hline Stewart & 43 \\
\hline Sumter & 50 \\
\hline Taylor & 1 \\
\hline Terrell & 8 \\
\hline Webster & 71 \\
\hline Total & 746 \\
\hline
\end{tabular}




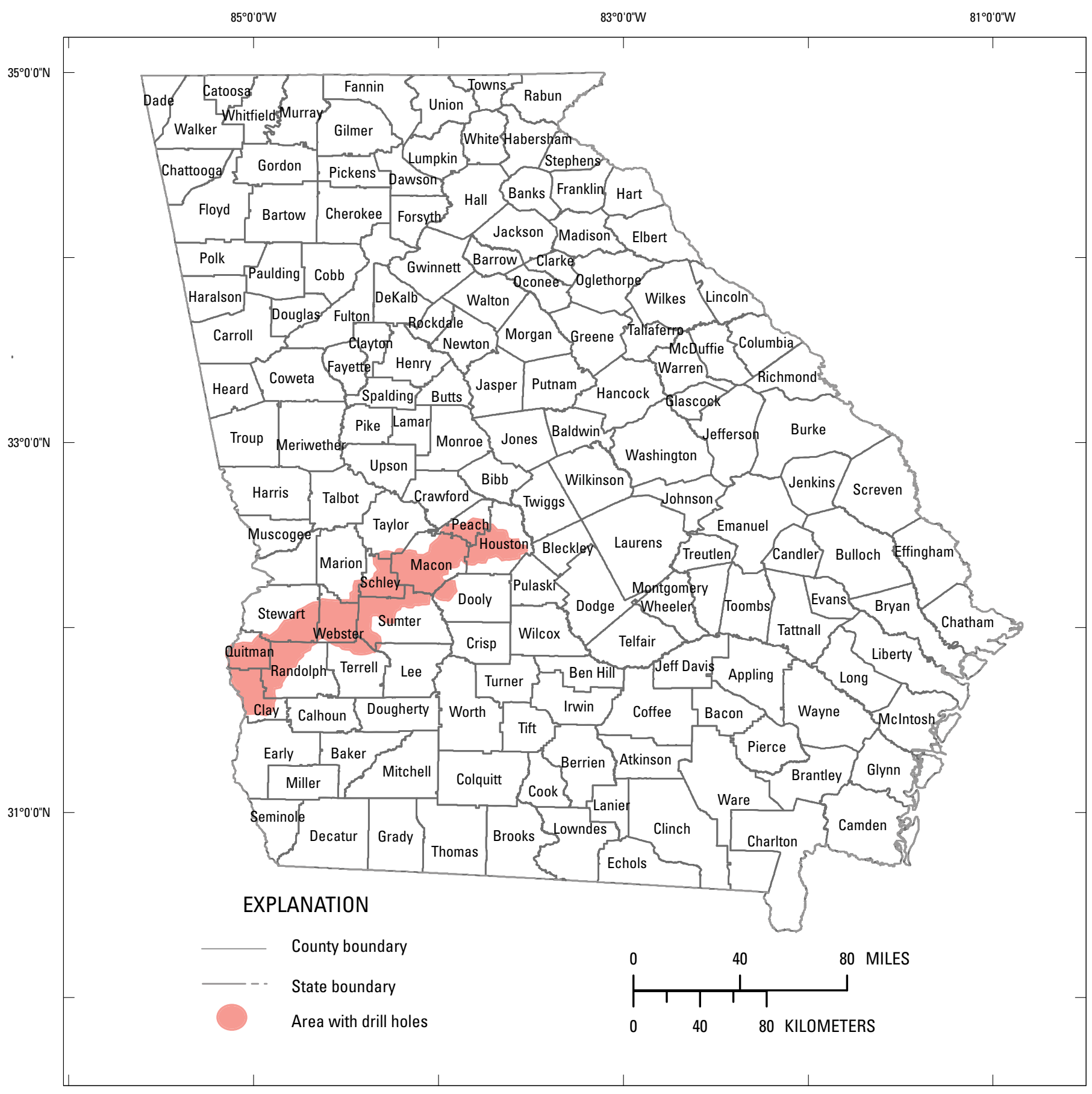

Figure C1. Map of Georgia showing locations of areas with drill holes. 

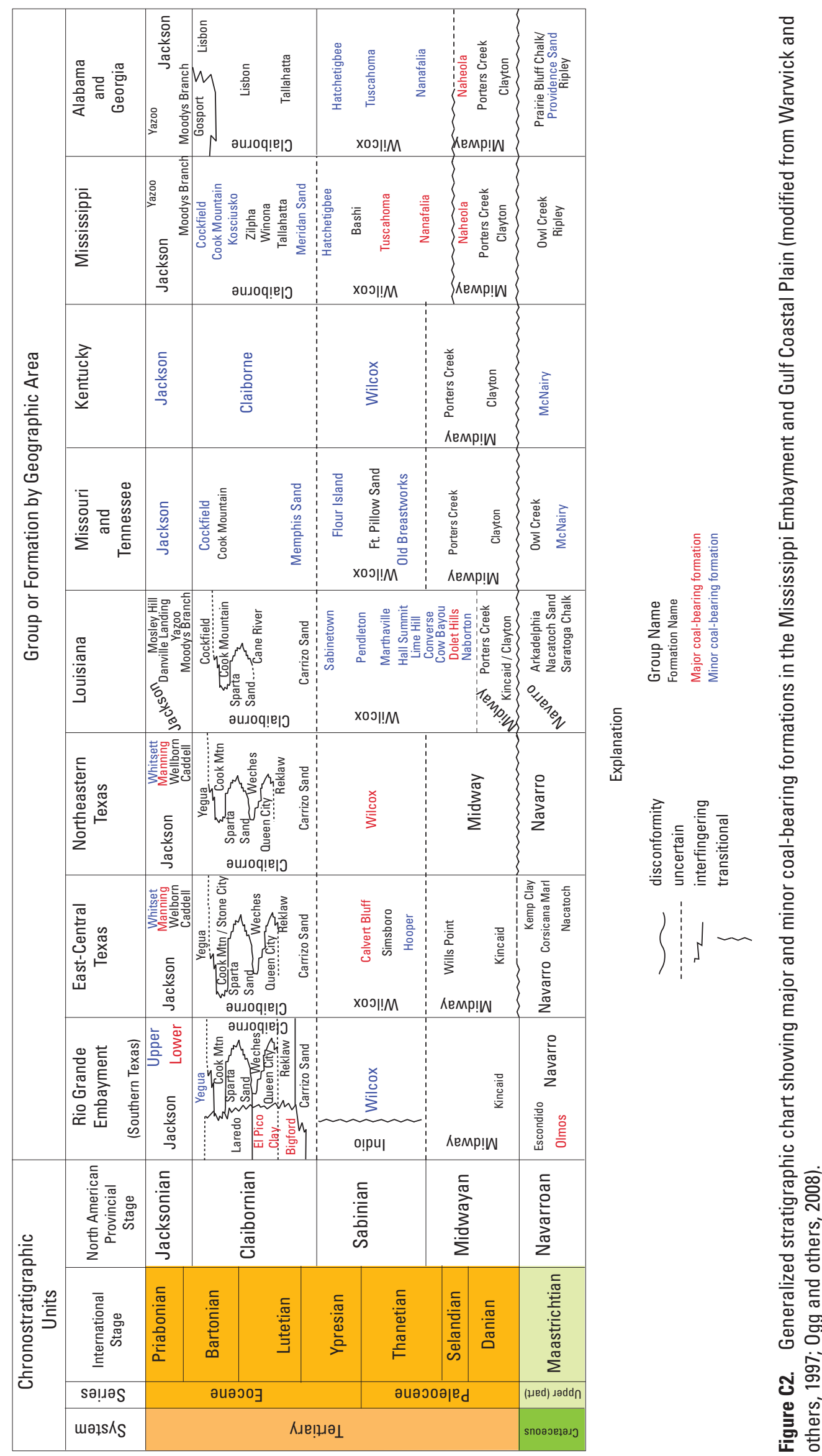


\section{Shallow Coal Exploration Drill-Hole Data, Western Kentucky}

By Christina A. DeVera, Krystina R. Scott-Sanchez, and Peter D. Warwick

Chapter D of

Shallow Coal Exploration Drill-Hole Data-Alabama, Georgia, Kentucky, Louisiana, Mississippi, Missouri, North Carolina, South Carolina, Tennessee, and Texas

Edited by Brett J. Valentine and Kristin O. Dennen

Open-File Report 2011-1261-D 
Suggested citation:

DeVera, C.A., Scott-Sanchez, K.R., and Warwick, P.D., 2012, Shallow coal exploration drill-hole data, western Kentucky, in Valentine, B.J., and Dennen, K.O., eds., Shallow coal exploration drill-hole data-Alabama, Georgia, Kentucky, Louisiana, Mississippi, Missouri, North Carolina, South Carolina, Tennessee, and Texas: U.S. Geological Survey Open-File Report 2011-1261, ch. D, 5 p. plus appendix. (Available online.) 


\section{Contents}

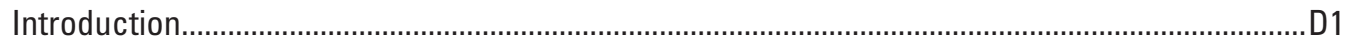

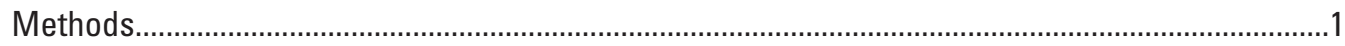

Generalized Coal Geology of Western Kentucky.............................................................................

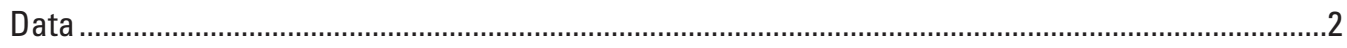

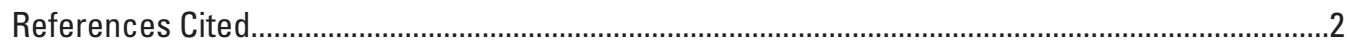

Appendix D1. Shallow Coal Exploration Drill-Hole Data for Western Kentucky ................................2

\section{Figures}

D1. Regional map of western Kentucky with generalized geology overlaid with

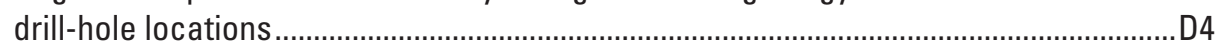

D2. Generalized stratigraphic chart showing major and minor coal-bearing formations in the Mississippi Embayment and Gulf Coastal Plain .....

\section{Tables}

D1. Attribute titles and data descriptions and formats for the western Kentucky drill-hole dataset.

D2. Explanation of comments used to describe the western Kentucky drill-hole

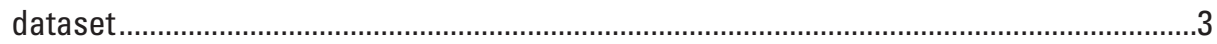

D3. Western Kentucky counties and the number of drill holes by county............................... 4 


\title{
Shallow Coal Exploration Drill-Hole Data, Western Kentucky
}

\author{
By Christina A. DeVera, Krystina R. Scott-Sanchez, and Peter D. Warwick
}

\section{Introduction}

Coal exploration drill-hole data from 657 wells in western Kentucky drilled between 1962 and 1981 by Phillips Coal Company, a division of Phillips Petroleum Company (Phillips), are discussed in this chapter, and the data are provided in an accompanying spreadsheet. The data are part of a larger dataset donated to the U.S. Geological Survey (USGS) by the North American Coal Corporation, which purchased Phillips assets in 2001 (see chapter A, this volume). The data in 10 State reports have been digitized from field maps to create unified and spatially consistent coal exploration drill-hole datasets for each of the States (chapters B-K, this volume). Data for western Kentucky include a geologic map of the State with drill-hole coverage (fig. D1), a list of data attributes and explanations of the data format (table D1), a list of comments found in the data and their explanations (table D2), a list of counties and the number of drill holes for each county (table D3), and tabulated data in spreadsheet format (see appendix D1).

\section{Methods}

Hardcopy Phillips exploration maps, in Kentucky South 1927 State coordinate plane projection, were digitized into a geographic information system using ArcMap ${ }^{\mathrm{TM}}$ software from the Environmental Systems Research Institute Inc. (ESRI). Roads and county boundaries served as reference points to georeference scanned maps. Shapefile attribute values were populated with data from drill-hole locations in eight counties in western Kentucky. Comments were added to the attribute table (table D1) to indicate notations made by the coal company as well as general observations made when digitizing the drill-hole points (table D2). The dataset was projected into a North American Datum of 1983 geographic coordinate system to facilitate combining this dataset with similar Phillips datasets published by the USGS for other States. The shapefile was exported to a spreadsheet (see appendix D1).

\section{Generalized Coal Geology of Western Kentucky}

Western Kentucky is a part of the Jackson Purchase area, which is comprised of the northernmost part of the Mississippi Embayment region of the Gulf Coastal Plain and contains sediments of Cretaceous through Quaternary ages (figs. D1, D2) (Cushing and others, 1964; Hackley and others, 2006). Lignite deposits are found in the Gulf Coastal Plain Coal Province that extends into western Kentucky (Cushing and others, 1964; Hackley and others, 2006). The lignite-bearing counties within the Jackson Purchase area of western Kentucky are Ballard, Carlisle, Calloway, Fulton, Graves, Hickman, Marshall and McCracken Counties (table D3) (Hackley and others, 2006). The Upper Cretaceous and Lower Tertiary strata of the Jackson Purchase area contain thin, discontinuous lignite beds (Olive and McDowell, 1986; Hackley and others, 2006). The majority of the lignite lenses in western Kentucky are found in the Wilcox, Claiborne, and Jackson Formations and, to a lesser extent, in the McNairy Formation (fig. D2) (Hackley and others, 2006).

The McNairy Formation is Upper Cretaceous in age containing marine and freshwater deltaic deposition that produced the lignite beds in this formation (Stephenson, 1914; Hackley and others, 2006). Sediments in the McNairy Formation were deposited in an environment with a subtropical climate, shown through pollen studies (Tschurdy, 1970; Hackley and others, 2006). The lignite in the McNairy Formation is found in northeastern Calloway County in a bed that is one and one-half feet thick (Olive, 1980; Hackley and others, 2006). Lignite from the McNairy Formation can also be found in the subsurface in McCracken County (Hower and others, 1990; Hackley and others, 2006). McNairy Formation lignite originated from allochthonous organic material (Hower and others, 1990; Hackley and others, 2006).

The Tertiary Age formations in the Jackson Purchase area are the Wilcox, Claiborne, and Jackson Groups. The Wilcox Group sediments are from the Paleocene/Eocene and were deposited in a freshwater environment (Olive, 1980; Hackley and others, 2006). Lignite lenses as thick as 3 feet can be found in northeastern Calloway County (Olive, 1980; Hackley and others, 2006), although they are relatively rare (Hower 
and others, 1990). The Wilcox Group also contains sands and clays that include lignitized plant material and leaf imprints (Olive, 1980; Hackley and others, 2006). In the Claiborne Group overlying the Wilcox Group, lignite can be found in beds generally less than 5 feet thick (Olive, 1980; Hackley and others, 2006). This lignite is locally composed of woody fragments of tree trunks and stumps (Olive, 1980; Hackley and others, 2006). Lignite of the Claiborne Group most likely formed from sediment that was deposited in an oxbow lake environment (Potter and Dilcher, 1980; Hower and others, 1990). The Jackson Formation overlies the Claiborne Group and is comprised of similar lithologies (Hackley and others, 2006). Underlying modern stream floodplains are Pliocene, Pleistocene, and Holocene aged sediments that include loess and alluvium. (Olive and Finch, 1969; Olive and McDowell, 1986; Hackley and others, 2006).

\section{Data}

The drill-hole dataset from western Kentucky is part of the data for lignite deposits in the Gulf Coast region (see fig. A1 in chapter A, this volume). A total of 657 drill-hole locations were in western Kentucky, with 31 drill holes that had recorded probe depths. Out of the 657 drill holes, 196 contained coal with an average thickness of 3.72 feet for the coal bed and partings. The minimum depth at which coal was found was 28 feet and the maximum coal depth was 292 feet. The majority of the drill holes with coal were found in Fulton County (244 drill holes containing coal) and to a lesser extent in Hickman County (146 drill holes containing coal) (table D3). There is a \pm 0.25 mile error in location due to the generalized nature of the drill-hole locations on the original highway maps and georeferencing those maps to a new base layer.

\section{References Cited}

Cushing, E.M., Boswell, E.H., and Hosman, R.L., 1964, General geology of the Mississippi Embayment: U.S. Geological Survey Professional Paper 448-B, 28 p.

Hackley, P.C., Warwick, P.D., Thomas, R.E., and Nichols, D.J., 2006, Review of lignite resources of Western Tennessee and the Jackson Purchase area, western Kentucky: U.S. Geological Survey Open-File Report 20061078, 34 p., pubs.usgs.gov/of/2006/1078.

Hower, J.C., Rich, F.J., Williams, D.A., Bland, A.E., and Fiene, F.L., 1990, Cretaceous and Eocene lignite deposits, Jackson Purchase, Kentucky: International Journal of Coal Geology, v. 16, p. 239-254.
Ogg, J.G., Ogg, Gabi, and Gradstein, F.M., 2008, The concise geologic time scale: Cambridge, U.K., Cambridge University Press, 184 p.

Olive, W.W., 1980, Geologic maps of the Jackson Purchase region, Kentucky: U.S. Geological Survey Miscellaneous Investigations Series Map I-1217, scale 1:250,000.

Olive, W.W., and Finch, W.I., 1969, Stratigraphic and mineralogic relations and ceramic properties of clay deposits of Eocene Age in the Jackson Purchase Region, Kentucky, and in adjacent parts of Tennessee: U.S. Geological Survey Bulletin 1282, 35 p.

Olive, W.W., and McDowell, R.C., 1986, Cretaceous and Tertiary systems: U.S. Geological Survey Professional Paper 1151-H, p. H46-H49.

Nicholson, S.W., Dicken, C.L., Horton, J.D., Labay, K.A., Foose, M.P., Mueller, J.A.L., 2005, Preliminary integrated geologic map databases for the United States: Kentucky, Ohio, Tennessee, and West Virginia: U.S. Geological Survey Open-file Report 2005-1324, Version 1.1 (updated December 2007), pubs.usgs.gov/of/2005/1324.

Potter, F.W., Jr., and Dilcher, D.L., 1980, Biostratigraphic analysis of Eocene clay deposits in Henry County, Tennessee, in Dilcher, D.L., and Taylor, T.N., eds., Biostratigraphy of fossil plants: Stroudsburg, Pa., Dowden, Hutchinson, and Ross, p. 211-225.

Stephenson, L.S., 1914, The Cretaceous-Eocene contact in the Atlantic and Gulf Coastal Plain: U.S. Geological Survey Professional Paper 90-J, p. 155-182.

Tschurdy, T.H., 1970, Two new pollen genera (Late Cretaceous and Paleocene) with possible affinity to the Illiciaceae: U.S. Geological Survey Professional Paper 643-F, 13 p.

Warwick, P.D., SanFilipo, J.R., Crowley, S.S., Thomas, R.E., and Freid, J., comps., and Tully, J.K., digital comp., 1997, Map showing outcrop of the coal-bearing units and land use in the Gulf Coast coal region: U.S. Geological Survey Open-File Report 97-172, 1 sheet, accessed April 20, 2011, at pubs.usgs.gov/of/1997/of97-172/.

\section{Appendix D1}

The western Kentucky coal exploration drill-hole dataset in spreadsheet format is available at pubs.usgs.gov/ of/2011/1261/Appendices/D1-KY.xls. 
Table D1. Attribute titles and data descriptions and formats for the western Kentucky drill-hole dataset.

\begin{tabular}{ll}
\hline \multicolumn{1}{c}{ Attribute title } & \multicolumn{1}{c}{ Data description and format } \\
\hline DRILL-HOLE NAME & Two-letter county code followed by drill-hole number. \\
COUNTY & The county where the drill hole was located. \\
ELEVATION & Elevation above sea level in feet. \\
DEPTH_TOTAL & Depth of drill hole in feet. \\
DEPTH_PROBED & Depth of geophysical probe measurement in feet. \\
LATITUDE & Decimal degree location values given to 4 decimal places. \\
LONGITUDE & Decimal degree location values given to 4 decimal places. \\
COMMENT & Additional information regarding the entire drill hole. \\
X_C & Thickness of coal for bed number X in decimal feet. \\
X_CP & Thickness of coal and partings combined for bed number X in decimal feet. \\
X_DEPTH & Top depth of bed number $X$ in feet. \\
X_BED & A number or letter assigned to different coal beds of the same drill hole, which are not correlated \\
& throughout the dataset. \\
X_COMMENT & Additional information regarding coal bed X. \\
\hline
\end{tabular}

Table D2. Explanation of comments used to describe the western Kentucky drill-hole dataset (modified from J.A. Luppens, U.S. Geological Survey, written commun., 2009).

\begin{tabular}{|c|c|}
\hline SYMBOL/COMMENT & DESCRIPTION \\
\hline ? & Questionable data/information. \\
\hline CORED & Indicating that the drill hole was cored. \\
\hline I & Abbreviation for “inferior.” Subjective term used to describe poor coal quality. \\
\hline LOCATION FROM LOG & $\begin{array}{l}\text { Locations were not digitized from coal exploration maps. The locations were acquired from sample } \\
\text { description sheets completed by the geologist onsite. The coordinates originally were in a State plane } \\
\text { coordinate system. }\end{array}$ \\
\hline NC & Abbreviation for "no coal.” No coal was found during exploration for this drill hole. \\
\hline NO DATA & No data were recorded on the original coal exploration maps for this drill hole. \\
\hline $\mathrm{NP}$ & Abbreviation for “not probed.” Geophysical logging never occurred at this location. \\
\hline NSL & $\begin{array}{l}\text { Abbreviation for "no significant lignite." Coal may have been found during exploration but because the } \\
\text { coal beds were thin (usually less than } 2 \text { feet thick) no coal data was recorded. }\end{array}$ \\
\hline PI & Abbreviation for "partially inferior." Used to describe that a portion of the coal bed is of a low quality. \\
\hline
\end{tabular}


Table D3. Western Kentucky counties and the number of drill holes by county.

\begin{tabular}{|c|c|}
\hline County & Number of drill holes \\
\hline Ballard & 52 \\
\hline Carlisle & 81 \\
\hline Calloway & 36 \\
\hline Fulton & 244 \\
\hline Graves & 75 \\
\hline Hickman & 146 \\
\hline Marshall & 6 \\
\hline McCracken & 17 \\
\hline Total & 657 \\
\hline
\end{tabular}

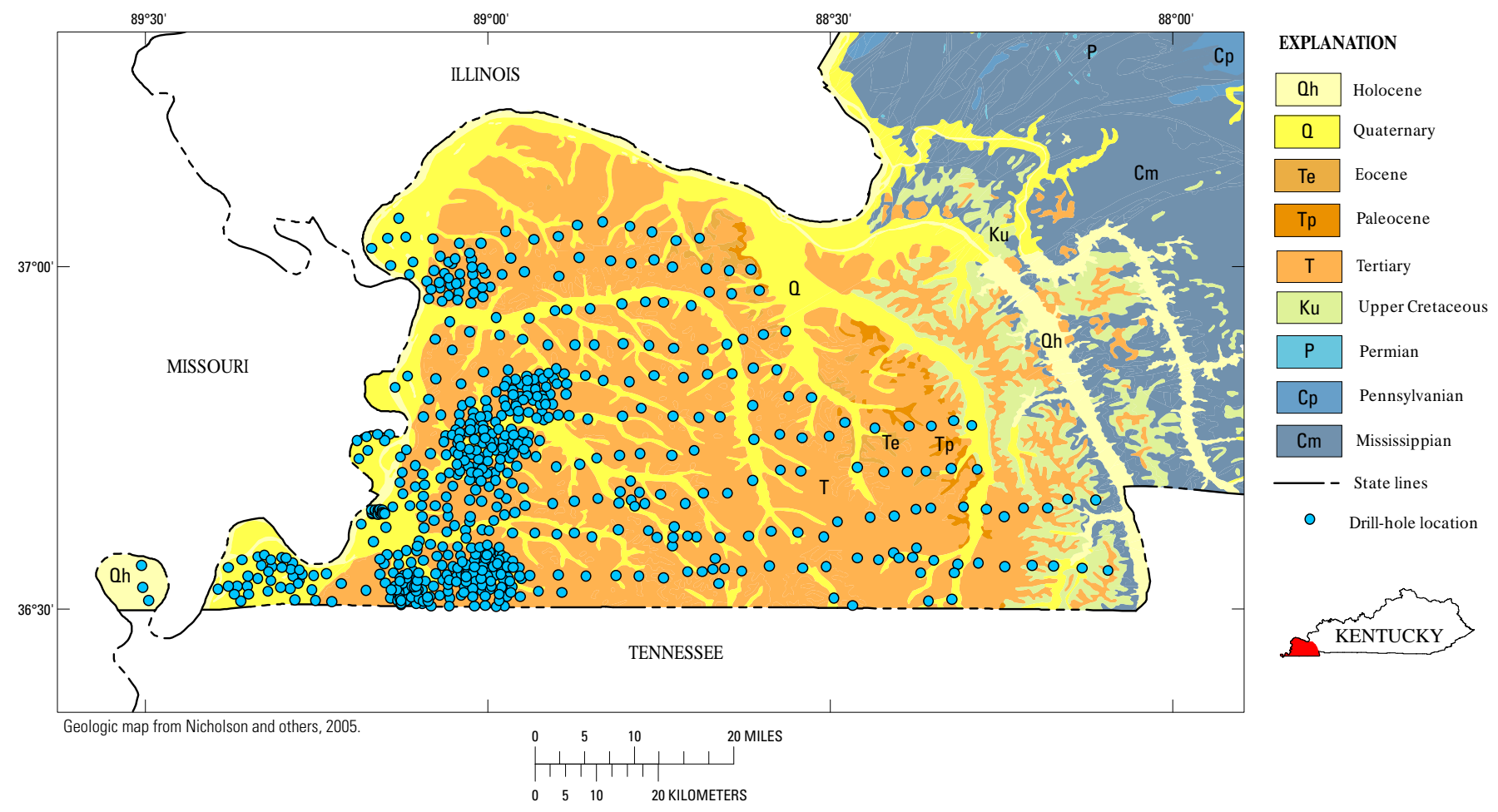

Figure D1. Regional map of western Kentucky with generalized geology overlaid with drill-hole locations. 

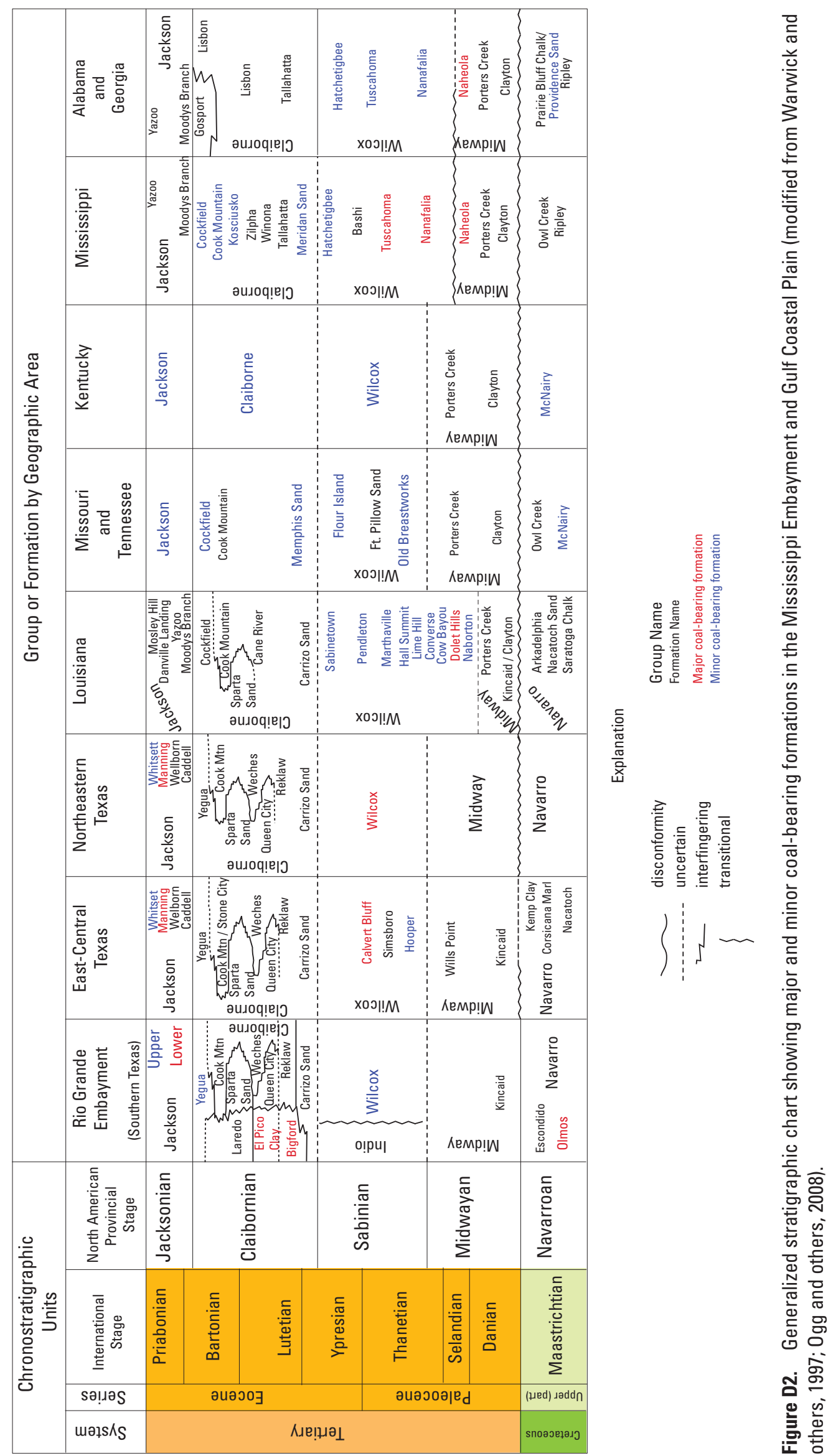


\section{Shallow Coal Exploration Drill-Hole Data, Northern Louisiana}

By Celeste D. Lohr, Krystina R. Scott-Sanchez, and Brett J. Valentine

Chapter E of

Shallow Coal Exploration Drill-Hole Data-Alabama, Georgia, Kentucky, Louisiana, Mississippi, Missouri, North Carolina, South Carolina, Tennessee, and Texas

Edited by Brett J. Valentine and Kristin O. Dennen

Open-File Report 2011-1261-E 
Suggested citation:

Lohr, C.D., Scott-Sanchez, K.R., and Valentine, B.J., 2012, Shallow coal exploration drill-hole data, northern Louisiana, in Valentine, B.J., and Dennen, K.O., eds., Shallow coal exploration drill-hole data-Alabama, Georgia, Kentucky, Louisiana, Mississippi, Missouri, North Carolina, South Carolina, Tennessee, and Texas: U.S. Geological Survey Open-File Report 2011-1261, ch. E, 6 p. plus appendix. (Available online.) 


\section{Contents}

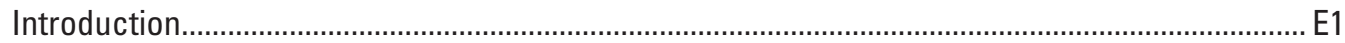

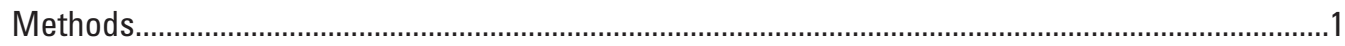

Generalized Coal Geology of Northern Louisiana .............................................................................

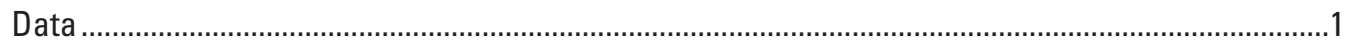

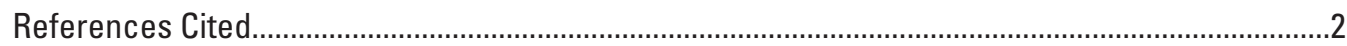

Appendix E1. Shallow Coal Exploration Drill-Hole Data for Northern Louisiana .............................2

\section{Figures}

E1. Map of northern Louisiana showing generalized geology overlaid with drill-hole

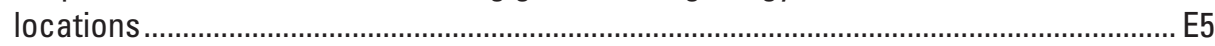

E2. Generalized stratigraphic chart showing major and minor coal-bearing formations in the Mississippi Embayment and Gulf Coastal Plain...

\section{Tables}

E1. Attribute titles and data descriptions and formats for the northern Louisiana drill-hole dataset.

E2. Explanation of comments used to describe the northern Louisiana drill-hole

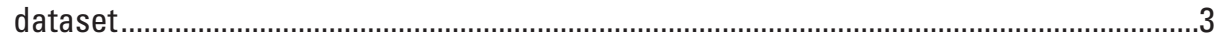

E3. Louisiana parishes and the number of drill holes by parish............................................. 


\title{
Shallow Coal Exploration Drill-Hole Data, Northern Louisiana
}

\author{
By Celeste D. Lohr, Krystina R. Scott-Sanchez, and Brett J. Valentine
}

\section{Introduction}

Coal exploration drill-hole data from 2,910 wells drilled in northern Louisiana between 1975 and 1984 by Phillips Coal Company, a division of Phillips Petroleum Company (Phillips), are discussed in this chapter, and the data are provided in an accompanying spreadsheet. The data are part of a larger dataset donated to the U.S. Geological Survey (USGS) by the North American Coal Corporation, which purchased Phillips assets in 2001 (see chapter A, this volume). The data in 10 State reports have been digitized from field maps to create unified and spatially consistent coal exploration drill-hole datasets for each of the States (chapters B-K, this volume). Data for Louisiana include a geologic map of the State with drill-hole coverage (fig. E1), a stratigraphic column (fig. E2), a list of data attributes and explanations of the data format (table E1), a list of comments found in the data and descriptions of them (table E2), a list of parishes and the number of drill holes for each parish (table E3), and tabulated data in spreadsheet format (see appendix E1).

\section{Methods}

Hardcopy Phillips exploration maps, in Louisiana North 1927 state coordinate plane projection, were digitized into a geographic information systems using ArcMap ${ }^{\mathrm{TM}}$ software from the Environmental Systems Research Institute, Inc. (ESRI). Roads and parish boundaries served as reference points to georeference scanned maps. Shapefile attribute values were populated with data from drill-hole locations in 18 parishes in northern Louisiana (table E3). The attribute table for each point (table E1) contains basic identification and location references along with depth and thickness data for each coal bed. Changes to the original data did not occur during the digitizing process in order to maintain the integrity of the dataset. Comments were added to the attribute table to indicate any discrepencies or additional information (table E2). After the digitizing was completed, the dataset was projected into a North American Datum of 1983 geographic coordinate system to facilitate combining this dataset with similar Phillips datasets published by the USGS for other States. The shapefile data were exported to a spreadsheet (see appendix E1).

\section{Generalized Coal Geology of Northern Louisiana}

In northern Louisiana, major coal (lignite)-bearing intervals are in the Tertiary Wilcox Group consisting of interbedded sandstone, siltstone, claystone, coal, and limestone (Nilsson, 1984; Warwick and others, 2008, and fig. E2). During the early Cenozoic, peat mires associated with fluvial and deltaic deposits developed across the northern margin of the basin (McIntosh and others, 2010). These peat mires, which are now coal beds, were stacked on a progradational fluvial-deltaic plain and influenced by the positive structural elements of the uplifts in the northeast and the west (Hackley and others, 2007). Lignite coal in the Wilcox Group occurs at depths of 200 feet or less from the surface and, on average, contains 0.81 percent sulfur, 10.72 percent ash, 27.08 percent volatile matter, and 27.09 percent fixed carbon (Louisiana Geological Survey, 2000).

\section{Data}

The northern Louisiana drill-hole dataset contains data on shallow lignite in the Gulf Coast region (fig. E1). Probed depth data for 2,014 drill holes (out of 2,910) had an average depth of 274 feet with a maximum depth of 325 feet. Red River Parish had the densest coverage with 616 drill holes. Bienville Parish also had dense coverage with 532 drill holes. Due to the generalized nature of the original highway maps that contained the drill-hole information and the process of georeferencing these maps to a new base layer, we expect the location error to be \pm 0.25 miles. 


\section{References Cited}

Hackley, P.C., Warwick, P.D., and Breland Jr., F.C., 2007, Organic petrology and coalbed gas content, Wilcox Group (Paleocene-Eocene), northern Louisiana: International Journal of Coal Geology, v. 71, p. 54-71.

Louisiana Geological Survey, 2000, Lignite resources in Louisiana, Public Information Series No. 5.

McIntosh, J.C., Warwick, P.D., Martini, A.M., and Osborn, S.G., 2010, Coupled hydrology and biogeochemistry of Paleocene-Eocene coal beds, northern Gulf of Mexico: Geological Society of America Bulletin, v. 122, no. 7/8, p. 1248-1264.

Nilsson, H.D., 1984, Deep-basin lignite in northwest Louisiana: Transactions - Gulf Coast Association of Geological Societies, v. 34, p. 183-186.

Ogg, J.G., Ogg, Gabi, and Gradstein, F.M., 2008, The concise geologic time scale: Cambridge, U.K., Cambridge University Press, 184 p.

Stoeser, D.B., Green, G.N., Morath, L.C., Heran, W.D., Wilson, A.B., Moore, D.W., and Van Gosen, B.S., 2005, Preliminary integrated geologic map databases for the United States central States-Montana, Wyoming, Colorado, New Mexico, Kansas, Oklahoma, Texas, Missouri, Arkansas, and Louisiana: U.S. Geological Survey Open-File Report 2005-1351, version 1.0.
Warwick, P.D., Breland Jr., F.C., and Hackley, P.C., 2008, Biogenic origin of coalbed gas in the northern Gulf of Mexico Coastal Plain, U.S.A.: International Journal of Coal Geology, v. 76, p. 119-137.

Warwick, P.D., SanFilipo, J.R., Crowley, S.S., Thomas, R.E., and Freid, J., comps., and Tully, J.K., digital comp., 1997, Map showing outcrop of the coal-bearing units and land use in the Gulf Coast coal region: U.S. Geological Survey Open-File Report 97-172, 1 sheet, accessed April 20, 2011, at http://pubs.usgs.gov/of/1997/of97-172/.

\section{Appendix E1}

The northern Louisiana coal exploration drill-hole dataset in spreadsheet format is available at pubs.usgs.gov/ of/2011/1261/Appendices/E1.xls.

Table E1. Attribute titles and data descriptions and formats for the northern Louisiana drill-hole dataset.

\begin{tabular}{ll}
\hline \multicolumn{1}{c}{ Attribute title } & \multicolumn{1}{c}{ Data description and format } \\
\hline DRILL_HOLE NAME & Two-letter parish code followed by drill-hole number. \\
PARISH & Name of parish in which drill hole is located. \\
ELEVATION & Elevation above sea level in feet. \\
DEPTH_TOT & Total depth of drill hole in feet. \\
DEPTH_PROB & Depth of geophysical probe measurement in feet. \\
LAT & Latitudinal decimal degree location values given to 8 decimal places. \\
LONG & Longitudinal decimal degree location values given to 8 decimal places. \\
COMMENT & Additional information regarding the entire drill hole. \\
X_C & Thickness of coal for bed number $X$ in feet. \\
X_CP & Thickness of coal and partings combined for bed number X in feet. \\
X_DEPTH & Top depth of bed number X in feet. \\
X_BED & A number or letter assigned to different coal beds of the same drill hole, which are not correlated through- \\
& out the dataset. \\
X_COMMENT & Additional information regarding coal bed X. \\
\hline
\end{tabular}


Table E2. Explanation of comments used to describe the northern Louisiana drill-hole dataset (J.A. Luppens, U.S. Geological Survey, written commun., 2009).

\begin{tabular}{|c|c|}
\hline Symbol/Comment & Description \\
\hline ? & Questionable data/information. \\
\hline+ & More coal than the amount that was recorded could be expected. \\
\hline CORED & Indicating that the drill hole was cored. \\
\hline $\mathrm{DH}$ & Abbreviation for “drill hole.” \\
\hline DUPLICATE DH NAME & $\begin{array}{l}\text { The drill-hole name was used for two different locations on the original coal exploration maps. } \\
\text { Abbreviation for inferior. Subjective term used to describe poor coal quality. }\end{array}$ \\
\hline I & Original coal exploration maps could not be accurately georeferenced due to insufficient reference points. \\
\hline INACCURATE LOCATION & Drill-hole location accuracy may be greater than 0.25 miles. \\
\hline NC & Abbreviation for "no coal." No coal was found during exploration for this drill hole. \\
\hline NO DATA RECORDED & No data was recorded on original coal exploration maps for this drill hole. \\
\hline NO DENSITY CURVE & No geophysical denisty data was recorded during exploration. \\
\hline NO ELEVATION RECORDED & No ground elevation information was recorded on the original coal exploration maps for this drill hole. \\
\hline NO E-LOG & No geophysical logging was completed for this drill hole. \\
\hline NO LOG & No geophysical logging was completed for this drill hole. \\
\hline $\begin{array}{l}\text { NO PROBE DEPTH RE- } \\
\text { CORDED }\end{array}$ & No probe depth information was recorded on original coal exploration maps for this drill hole. \\
\hline NP & Abbreviation for “not probed.” Geophysical logging never occurred at this location. \\
\hline NSL & $\begin{array}{l}\text { Abbreviation for "no significant lignite." Coal may have been found during exploration but because the } \\
\text { coal beds were thin (usually less than } 2 \text { feet thick) no coal data was recorded. }\end{array}$ \\
\hline OTC & $\begin{array}{l}\text { Notation is on the original coal exploration maps and is listed either by itself under the drill-hole name } \\
\text { and elevation or it is listed with a depth range (example: OTC }\left(0-128^{\prime}\right) \text { ). No information about the } \\
\text { definition of this notation is listed on any of the Phillips coal exploration maps or drilling logs. The } \\
\text { meaning of the notation is unknown. }\end{array}$ \\
\hline OX & Abbreviation for "oxidized" or "oxidation." \\
\hline PI & Abbreviation for "partially inferior." Used to describe that a portion of the coal bed is of a low quality. \\
\hline POOR & A subjective term used to describe coal of poor quality. \\
\hline PUNKY LIGNITE & Describing a poor quality lignite. \\
\hline SPLIT & Comment was written next to coal beds that may contain a layer of high ash partings. \\
\hline VI & Abbreviation for "very inferior." Subjective term used to describe coal of a very low quality. \\
\hline WEATHERED & Used to describe coal that has been altered by chemical or physical means. \\
\hline WO & $\begin{array}{l}\text { Abbreviation for "washout." Occurs when a friable layer of material is eroded in the bore hole and the } \\
\text { well diameter is enlarged. }\end{array}$ \\
\hline
\end{tabular}


Table E3. Louisiana parishes and the number of drill holes by parish.

\begin{tabular}{|c|c|}
\hline Parish & Number of drill holes \\
\hline Bienville & 532 \\
\hline Bossier & 92 \\
\hline Caddo & 143 \\
\hline Caldwell & 31 \\
\hline Claiborne & 177 \\
\hline De Soto & 379 \\
\hline East Carroll & 40 \\
\hline Franklin & 75 \\
\hline Lincoln & 100 \\
\hline Morehouse & 56 \\
\hline Natchitoches & 139 \\
\hline Ouachita & 70 \\
\hline Red River & 616 \\
\hline Richland & 143 \\
\hline Sabine & 41 \\
\hline Union & 67 \\
\hline Webster & 93 \\
\hline West Carroll & 116 \\
\hline Total & 2,910 \\
\hline
\end{tabular}




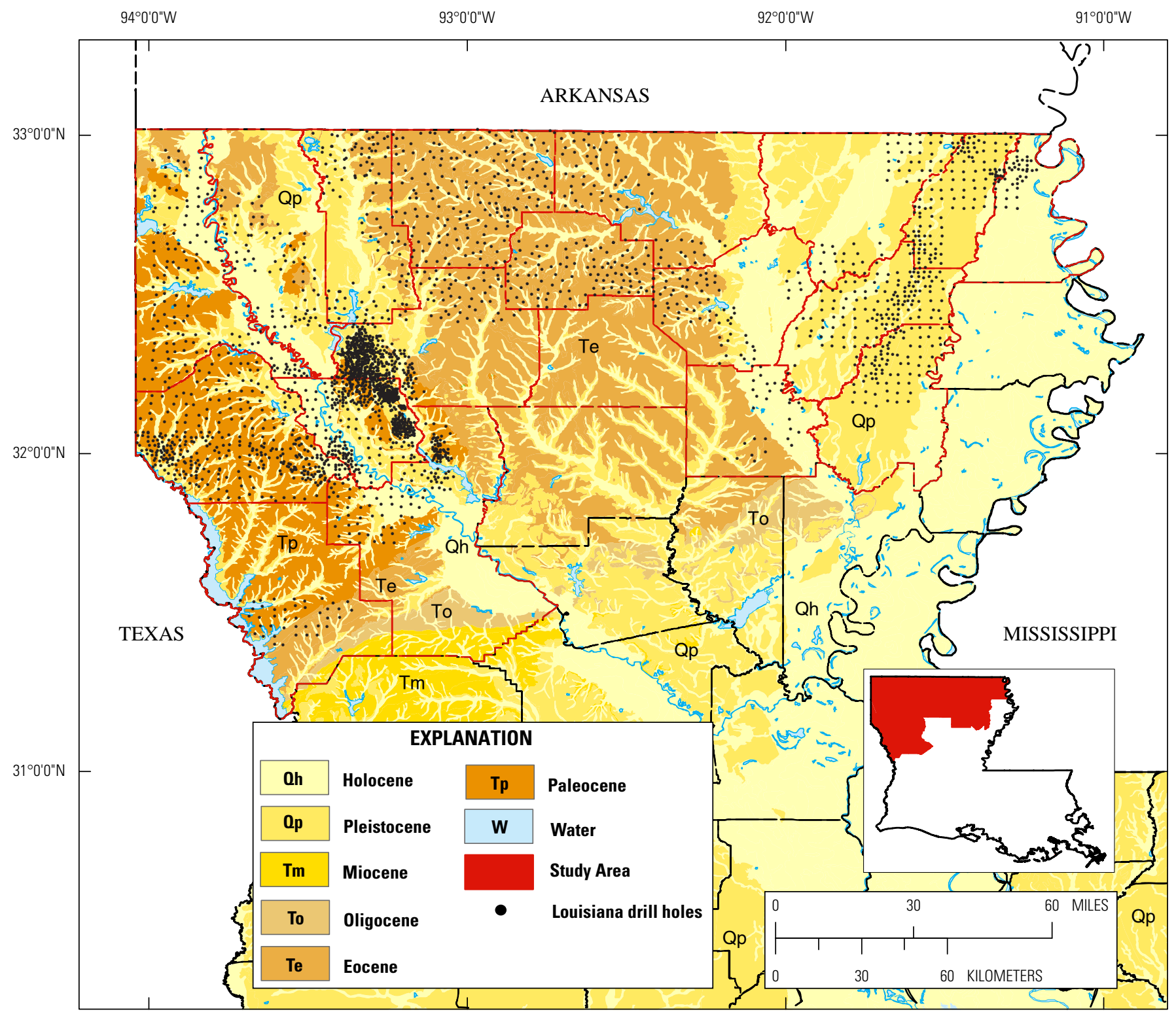

Geologic map by Stoeser and others (2005).

Figure E1. Map of northern Louisiana showing generalized geology overlaid with drill-hole locations. 


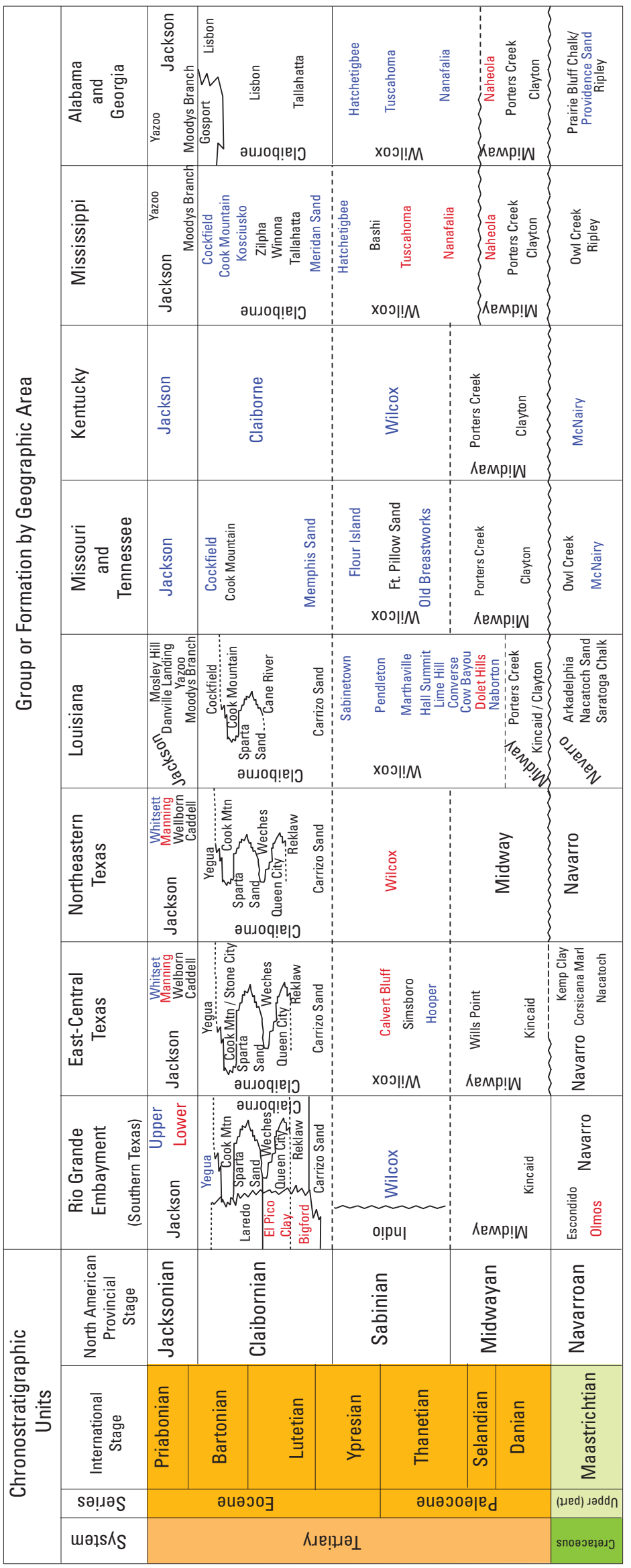

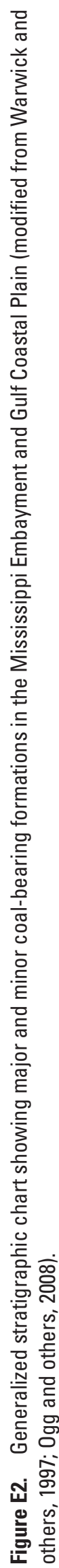




\section{Shallow Coal Exploration Drill-Hole Data, Mississippi}

By Matthew D. Merrill, Peter D. Warwick, and Christopher R. Burr

Chapter F of

Shallow Coal Exploration Drill-Hole Data-Alabama, Georgia, Kentucky, Louisiana, Mississippi, Missouri, North Carolina, South Carolina, Tennessee, and Texas

Edited by Brett J. Valentine and Kristin O. Dennen

Open-File Report 2011-1261-F 
Suggested citation:

Merrill, M.D., Warwick, P.D., and Burr, C.R., 2012, Shallow coal exploration drill-hole data, Mississippi, in Valentine, B.J., and Dennen, K.O., eds., Shallow coal exploration drill-hole data-Alabama, Georgia, Kentucky, Louisiana, Mississippi, Missouri, North Carolina, South Carolina, Tennessee, and Texas: U.S. Geological Survey Open-File Report 2011-1261, ch. F, 5 p. plus appendix. (Available online.) 


\section{Contents}

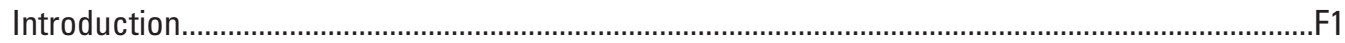

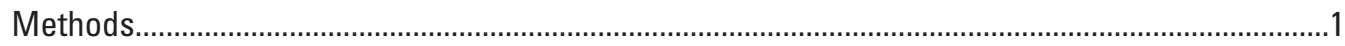

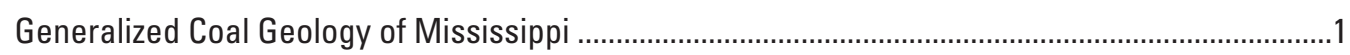

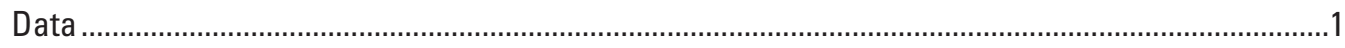

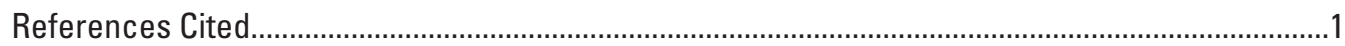

Appendix F1. Shallow Coal Exploration Drill-Hole Data for Mississippi ............................................2

\section{Figures}

F1. Map of Mississippi showing locations of areas with drill holes........................................F4

F2. Generalized stratigraphic chart showing major and minor coal-bearing formations in the Mississippi Embayment and Gulf Coastal Plain ....

\section{Tables}

F1. Attribute titles and data descriptions and formats for the Mississippi coal exploration drill-hole dataset..

F2. Explanation of comments used to describe the Mississippi drill-hole dataset. ................2

F3. Mississippi counties and the number of drill holes by county......................................... 


\title{
Shallow Coal Exploration Drill-Hole Data, Mississippi
}

\author{
By Matthew D. Merrill, Peter D. Warwick, and Christopher R. Burr
}

\section{Introduction}

Coal exploration drill-hole data from 2,789 wells drilled in Mississippi between 1975 and 1976 by Phillips Coal Company, a division of Phillips Petroleum Company (Phillips), are discussed in this chapter, and the data are provided in an accompanying spreadsheet. The data are part of a larger dataset donated to the U.S. Geological Survey by the North American Coal Corporation, which purchased Phillips assets in 2001 (see chapter A, this volume). The data in 10 State reports have been digitized from field maps to create unified and spatially consistent coal exploration drill-hole datasets for each of the States (chapters B-K, this volume). Data for Mississippi include a map of the State showing areas with drill-hole coverage (fig. F1), a list of data attributes and explanations of the data format (table F1), a list of comments found in the data and descriptions of them (table F2), a list of counties and the number of drill holes for each county (table F3), and tabulated data in spreadsheet format (see appendix F1).

\section{Methods}

Annotated field and county highway maps from Phillips, at scales from 1:62,500 to 1:100,000, were utilized to display the original data. Drill-hole locations in Mississippi 1927 State coordinate plane projection were digitized from hardcopy maps into a geographic information system using ArcMap ${ }^{\mathrm{TM}}$ software from the Environmental Systems Research Institute, Inc. (ESRI). Fiducial marks and county boundaries served as reference points. Maps were scanned and georeferenced; drillhole locations were digitized, and shapefile attribute values were populated with data from the maps. Once the digitizing of the maps was complete, the spatial data were then projected into a North American Datum of 1983 geographic coordinate system in order to standardize all of the Phillips datasets into a common projection. The shapefile data were exported to a spreadsheet (see appendix F1).

\section{Generalized Coal Geology of Mississippi}

This dataset explores resources in the Gulf Coast coal region of Mississippi (fig. F2). Coal-bearing strata in this region includes the Claiborne Group (Cockfield, Cook Mountain, Kosciusko, and Meridan Sand Formations), Wilcox Group (Hatchetigbee, Tuscahoma, and Nanafalia Formations), and the Midway Group (Naheola Formations) (Warwick and others, 1997).

\section{Data}

The Mississippi data provide drill-hole coverage in eastern Mississippi (fig. F1). Location error, due to the reduced resolution and generalized nature of highway maps, is expected to be \pm 0.25 miles. Shapefile attributes include all original raw data from the Phillips coal drill-hole location maps (table F1). The shapefile was exported to a spreadsheet (see appendix F1).

\section{References Cited}

Ogg, J.G., Ogg, Gabi, and Gradstein, F.M., 2008, The concise geologic time scale: Cambridge, U.K., Cambridge University Press, 184 p.

Warwick, P.D., SanFilipo, J.R., Crowley, S.S., Thomas, R.E., and Freid, J., comps., and Tully, J.K., digital comp., 1997, Map showing outcrop of the coal-bearing units and land use in the Gulf Coast coal region: U.S. Geological Survey Open-File Report 97-172, 1 sheet, accessed April 20, 2011, at pubs.usgs.gov/of/1997/of97-172/. 


\section{Appendix F1}

The Mississippi coal exploration drill-hole dataset in spreadsheet format is available at pubs.usgs.gov/of/2011/1261/ Appendices/F1-MS.xls.

Table F1. Attribute titles and data descriptions and formats for the Mississippi coal exploration drill-hole dataset.

\begin{tabular}{ll}
\hline \multicolumn{1}{c}{ Attribute title } & \multicolumn{1}{c}{ Data description and format } \\
\hline DRILL-HOLE NAME & A one- or two-letter county code followed by the drill-hole number. \\
COUNTY & County where the drill hole is located. \\
ELEVATION & Elevation above sea level in feet. \\
LATITUDE & Decimal degree location values given to 4 decimal places. \\
LONGITUDE & Decimal degree location values given to 4 decimal places. \\
X_C & Thickness of coal for bed number $\mathrm{X}$ in decimal feet. \\
X_CP & Thickness of coal and partings combined for bed number $\mathrm{X}$ in decimal feet. \\
X_DEPTH & Top depth of bed number $\mathrm{X}$ in feet. \\
COMMENT & Additional information regarding the drill hole. \\
\hline
\end{tabular}

Table F2. Explanation of comments used to describe the Mississippi drill-hole dataset (J.A. Luppens, U.S. Geological Survey, written commun., 2009).

\begin{tabular}{ll}
\hline \multicolumn{1}{c}{ Symbol/Comment } & Description \\
Good Coal & Comment was listed on the original coal exploration maps, but no coal data were recorded. The exact \\
meaning is not clear, but the comment seems to indicate that coal was encountered during exploration \\
and that it was of either a good quality or quantity. \\
Abbreviation for "no coal." No coal was found during exploration for this drill hole. \\
NC \\
NSL \\
Abbreviation for "no significant lignite." Coal may have been found during exploration but because the \\
coal beds were thin (usually less than 2 feet thick) no coal data were recorded. \\
Abbreviation for "not probed." Geophysical logging never occurred at this location.
\end{tabular}


Table F3. Mississippi counties and the number of drill holes by county.

\begin{tabular}{|c|c|}
\hline County & Number of drill holes \\
\hline Attala & 79 \\
\hline Benton & 94 \\
\hline Calhoun & 259 \\
\hline Choctaw & 282 \\
\hline Grenada & 29 \\
\hline Holmes & 241 \\
\hline Kemper & 326 \\
\hline Lafayette & 234 \\
\hline Lauderdale & 192 \\
\hline Leake & 46 \\
\hline Madison & 54 \\
\hline Neshoba & 173 \\
\hline Newton & 12 \\
\hline Pontotoc & 16 \\
\hline Tallahatchie & 86 \\
\hline Webster & 323 \\
\hline Winston & 298 \\
\hline Yazoo & 45 \\
\hline Total & 2,789 \\
\hline
\end{tabular}




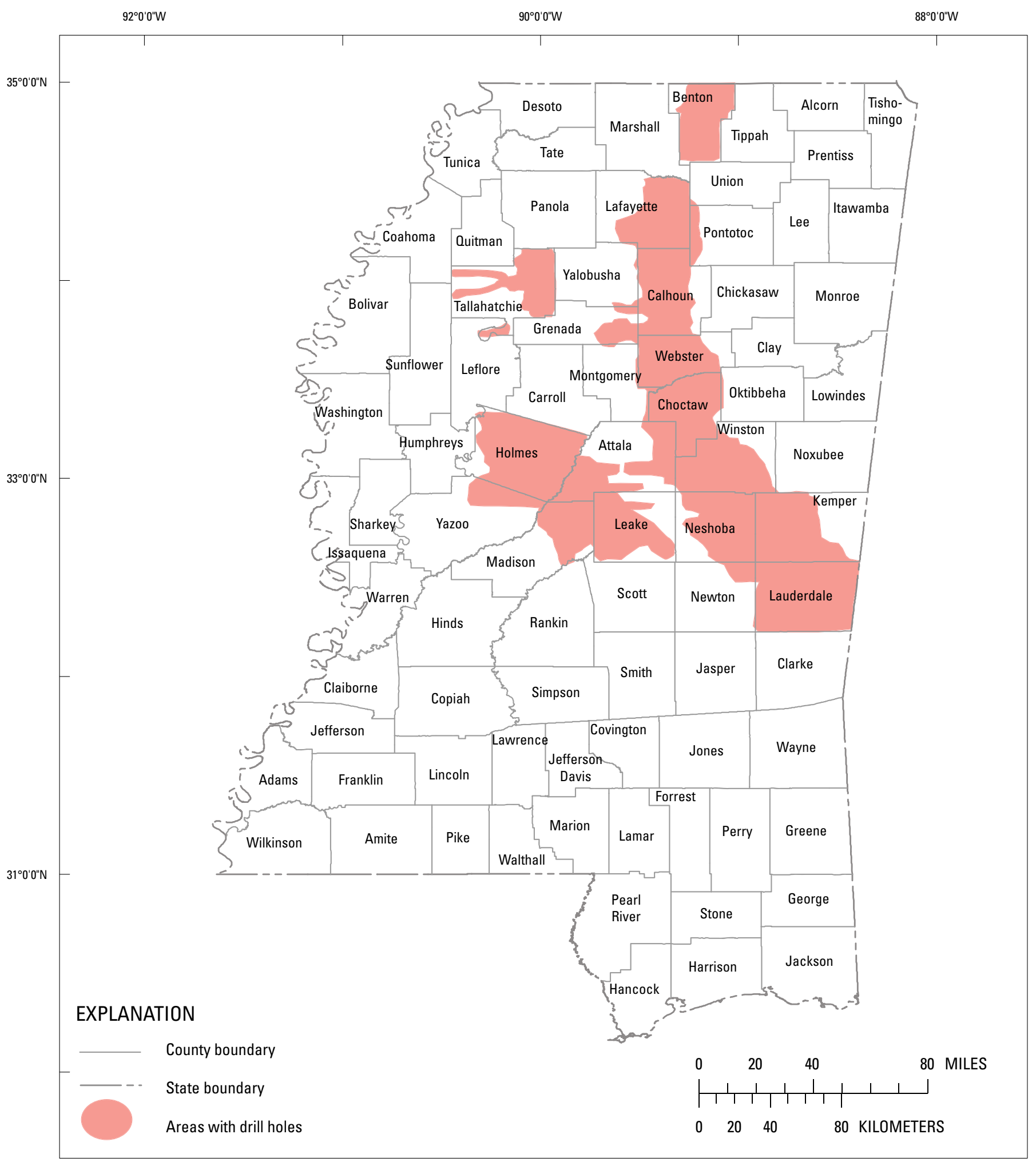

Figure F1. Map of Mississippi showing locations of areas with drill holes. 

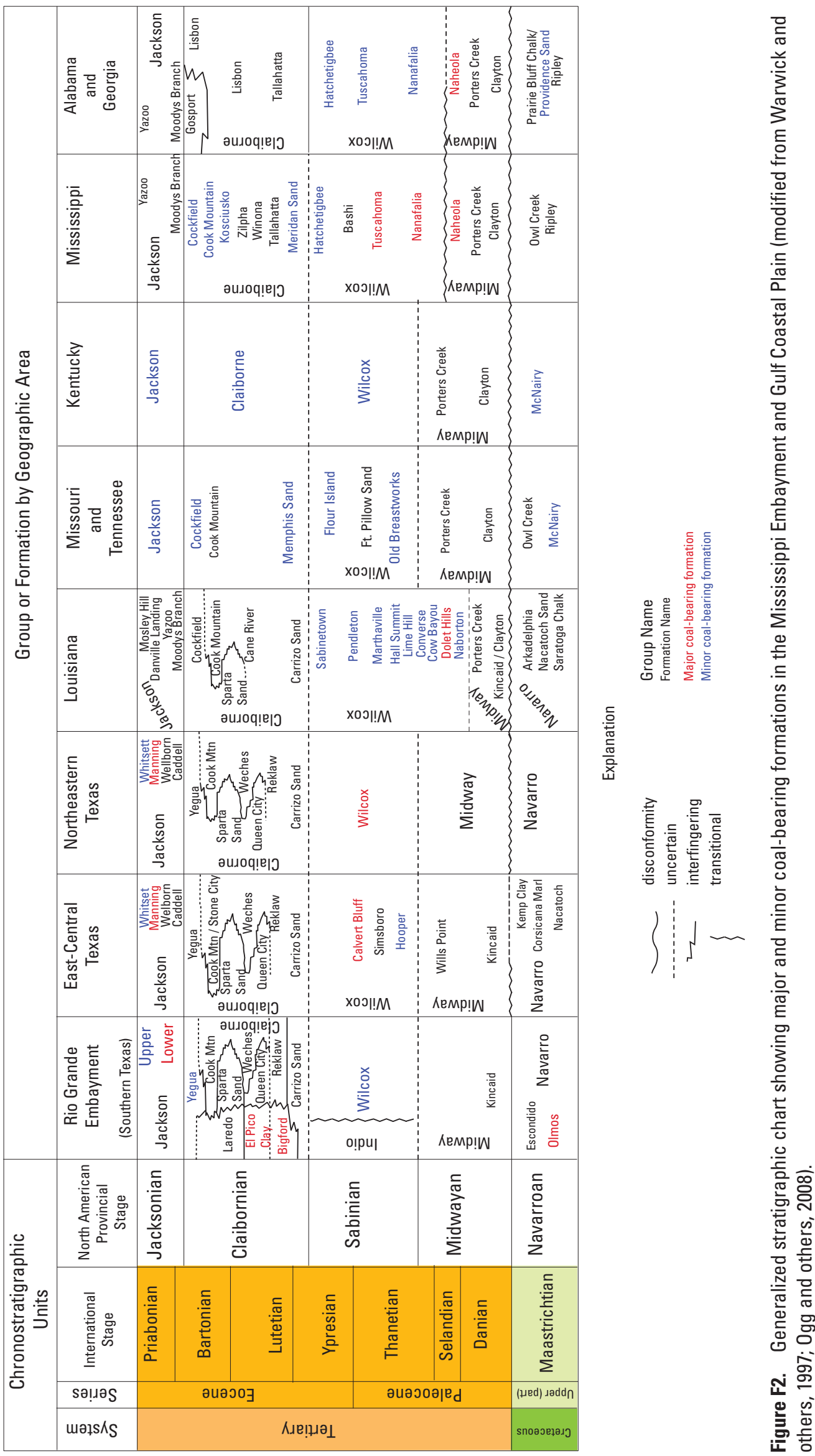


\section{Shallow Coal Exploration Drill-Hole Data, Southeastern Missouri}

By Brett J. Valentine, Krystina R. Scott-Sanchez, Christina A. DeVera, and Peter D. Warwick

Chapter $\mathrm{G}$ of

Shallow Coal Exploration Drill-Hole Data-Alabama, Georgia, Kentucky, Louisiana, Mississippi, Missouri, North Carolina, South Carolina, Tennessee, and Texas

Edited by Brett J. Valentine and Kristin O. Dennen

Open-File Report 2011-1261-G 
Suggested citation:

Valentine, B.J., Scott-Sanchez, K.R., DeVera, C.A., and Warwick, P.D., 2012, Shallow coal exploration drill-hole data, southeastern Missouri, in Valentine, B.J., and Dennen, K.O., eds., Shallow coal exploration drill-hole data-Alabama, Georgia, Kentucky, Louisiana, Mississippi, Missouri, North Carolina, South Carolina, Tennessee, and Texas: U.S. Geological Survey Open-File Report 2011-1261, ch. G, 5 p. plus appendix. (Available online.) 


\section{Contents}

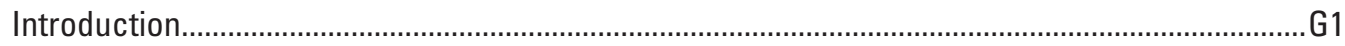

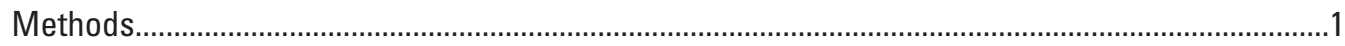

Generalized Coal Geology of Southeastern Missouri.........................................................................

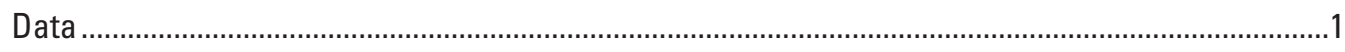

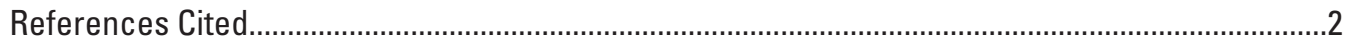

Appendix G1. Shallow Coal Exploration Drill-Hole Data for Southeastern Missouri ........................2

\section{Figures}

G1. Regional Missouri map with generalized geology overlaid with drill-hole

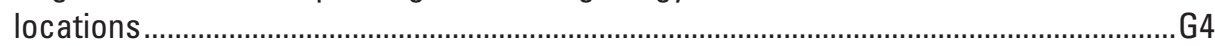

G2. Generalized stratigraphic chart showing major and minor coal-bearing formations in the Mississippi Embayment and Gulf Coastal Plain ..... .5

\section{Tables}

G1. Attribute titles and data descriptions and formats for the southeastern Missouri drill-hole dataset.

G2. Explanation of comments used to describe the southeastern Missouri

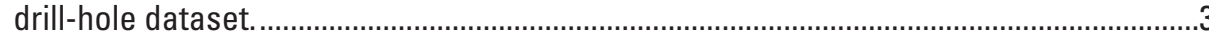

G3. Southeastern Missouri counties and the number of drill holes by county........................3 


\title{
Shallow Coal Exploration Drill-Hole Data, Southeastern Missouri
}

\author{
By Brett J. Valentine, Krystina R. Scott-Sanchez, Christina A. DeVera, and Peter D. Warwick
}

\section{Introduction}

Coal exploration drill-hole data from 1,049 wells in southeastern Missouri drilled between 1976 and 1978 by Phillips Coal Company, a division of Phillips Petroleum Company (Phillips), are discussed in this chapter, and the data are provided in an accompanying spreadsheet. The data are part of a larger dataset donated to the U.S. Geological Survey (USGS) by the North American Coal Corporation, which purchased Phillips assets in 2001 (see chapter A, this volume). The data in these reports have been digitized from field maps to create unified and spatially consistent coal exploration drill-hole datasets for each of the States (chapters B-K, this volume). Data for southeastern Missouri include a geologic map of the State with drill-hole coverage (fig. G1), a list of data attributes and explanations of the data format (table G1), a list of comments found in the data and descriptions of them (table G2), a list of counties and the number of drill holes for each county (table G3), and tabulated data in spreadsheet format (see appendix G1).

\section{Methods}

Hardcopy Phillips exploration maps, in Missouri East 1927 State coordinate plane projection, were scanned and georeferenced into a geographic information system (GIS) using ArcMap ${ }^{\mathrm{TM}}$ software from the Environmental Systems Research Institute, Inc. (ESRI). Drill-hole locations were then digitized into the GIS, and all coal data were recorded into an attribute table for each drill-hole point. Each data point is uniquely labeled with a two-letter county code followed by a numeral. The attribute table for each point contains basic site information and location references along with information on the coal beds found during exploration (table G1). For example, drill-hole locations where coal was found will have beds numbered sequentially (that is, 1,2,3...15), followed by thickness of the coal bed (1_C), thickness of coal and partings (1_CP), depth to the top of the bed (1_DEPTH), a bed regional name (1_BED), and any comments about quality or other information in regard to the coal bed (1_COMMENTS) (table G2). All of the depth and thickness measurements are measured in decimal feet. Comments have been added by USGS staff if there were problems or uncertainties during compiling or if any additional information on the maps needed to be described. Once the digitizing of the maps was complete, the spatial data were then projected into a North American Datum of 1983 geographic coordinate system in order to standardize all the Phillips datasets into a common projection. The shapefile data were exported to a spreadsheet (see appendix G1).

\section{Generalized Coal Geology of Southeastern Missouri}

The surface geology of southeastern Missouri is dominated by Quaternary aged alluvial sediments, with Tertiary and Upper Cretaceous outcrops that extend to the northeast out of Arkansas with Ordovician bedrock bounding the Gulf Coast sediments to the northwest (fig. G1). The major coal-bearing formations of this region are of Tertiary Age and are separated into the Wilcox, Claiborne, and Jackson Groups that formed in a cyclic nearshore deltaic environment (fig. G2). Most of the coal beds form lenses that have limited areal extent, making it difficult to correlate beds across the region (Oman, 1986).

\section{Data}

The southeastern Missouri coal exploration drill-hole dataset contains information on coals in seven counties within the Gulf Coast (fig. G1, table G3). Of the 1,049 drill holes, 593 drill holes are noted as no coal found during exploration, 161 drill holes are listed as "no significant lignite" (NSL), and the remaining 278 drill-hole locations record coal-bed penetrations. Exploration depth ranged from a minimum of 42 feet to a maximum exploration depth of 297 feet. Due to the generalized nature of the original highway maps that contained the drill-hole information and the process of georeferencing these maps to a new base layer, location error is expected to be \pm 0.25 miles. 


\section{References Cited}

Ogg, J.G., Ogg, Gabi, and Gradstein, F.M., 2008, The concise geologic time scale: Cambridge, U.K., Cambridge University Press, 184 p.

Oman, J.K., 1986, Stratigraphic framework and correlation of the Tertiary lignite-bearing formations from southeast Missouri to the Fort Pillow test well of west Tennessee: U.S. Geological Survey Bulletin 1644, 7 p.

Stoeser, D.B., Green, G.N., Morath, L.C., Heran, W.D., Wilson, A.B., Moore, D.W., and Van Gosen, B.S., 2005, Preliminary integrated geologic map databases for the United States central States-Montana, Wyoming, Colorado, New Mexico, Kansas, Oklahoma, Texas, Missouri, Arkansas, and Louisiana: U.S. Geological Survey Open-File Report 2005-1351, version 1.0.
Warwick, P.D., SanFilipo, J.R., Crowley, S.S., Thomas, R.E., and Freid, J., comps., and Tully, J.K., digital comp., 1997, Map showing outcrop of the coal-bearing units and land use in the Gulf Coast coal region: U.S. Geological Survey Open-File Report 97-172, 1 sheet, accessed April 20, 2011 at pubs.usgs.gov/of/1997/of97-172/.

\section{Appendix G1}

The Southeastern Missouri coal exploration drill-hole dataset in spreadsheet format is available at pubs.usgs.gov/ of/2011/1261/Appendices/G1-MO.xls.

Table G1. Attribute titles and data descriptions and formats for the southeastern Missouri drill-hole dataset.

\begin{tabular}{ll}
\hline \multicolumn{1}{c}{ Attribute title } & \multicolumn{1}{c}{ Data description and format } \\
\hline DRILL_HOLE NAME & Two-letter county code followed by drill-hole number. \\
COUNTY & County where the drill hole is located. \\
ELEVATION & Elevation above sea level in feet. \\
DEPTH_TOTAL & Depth of drill hole in feet. \\
DEPTH_PROBED & Depth of geophysical probe measurement in feet. \\
LATITUDE & Decimal degree location values given to 4 decimal places. \\
LONGITUDE & Decimal degree location values given to 4 decimal places. \\
COMMENT & Additional information regarding the entire drill hole. \\
X_C & Thickness of coal for bed number $\mathrm{X}$ in feet. \\
X_CP & Thickness of coal and partings combined for bed number X in feet. \\
X_DEPTH & Top depth of bed number $\mathrm{X}$ in feet. \\
X_BED & Regional name for coal bed X. \\
X_COMMENT & Additional information regarding coal bed X. \\
\hline
\end{tabular}


Table G2. Explanation of comments used to describe the southeastern Missouri drill-hole dataset (modified from J.A. Luppens, U.S. Geological Survey, written commun., 2009).

\begin{tabular}{ll}
\hline \multicolumn{1}{c}{ Comment } & \multicolumn{1}{c}{ Description } \\
\hline$?$ & Questionable data/information. \\
CORED & Indicating that the drill hole was cored. \\
DH & Abbreviation for "drill hole." \\
I & Abbreviation for inferior. Subjective term used to describe poor coal quality. \\
NP & Abbreviation for "no coal." No coal was found during exploration for this drill hole. \\
NSL & Abbreviation for "not probed." Geophysical logging never occurred at this location. \\
& Abbreviation for "no significant lignite." Coal may have been found during exploration but because the \\
ODD DH SYMBOL & coal beds were thin (usually less than 2 feet thick) no coal data were recorded. \\
& Location symbol on the original coal exploration maps was square. The meaning of the square symbol is \\
& unknown. The majority of drill-hole locations on the Phillips coal exploration maps were marked with \\
PI & a circle; or if the drill hole was cored, a triangle was used. \\
\hline
\end{tabular}

Table G3. Southeastern Missouri counties and the number of drill holes by county.

\begin{tabular}{lc}
\hline \multicolumn{1}{c}{ County } & Number of drill holes \\
\hline Butler & 43 \\
Dunklin & 198 \\
Mississippi & 214 \\
New Madrid & 171 \\
Pemiscot & 196 \\
Scott & 68 \\
Stoddard & 159 \\
$\quad$ Total & 1,049 \\
\hline
\end{tabular}



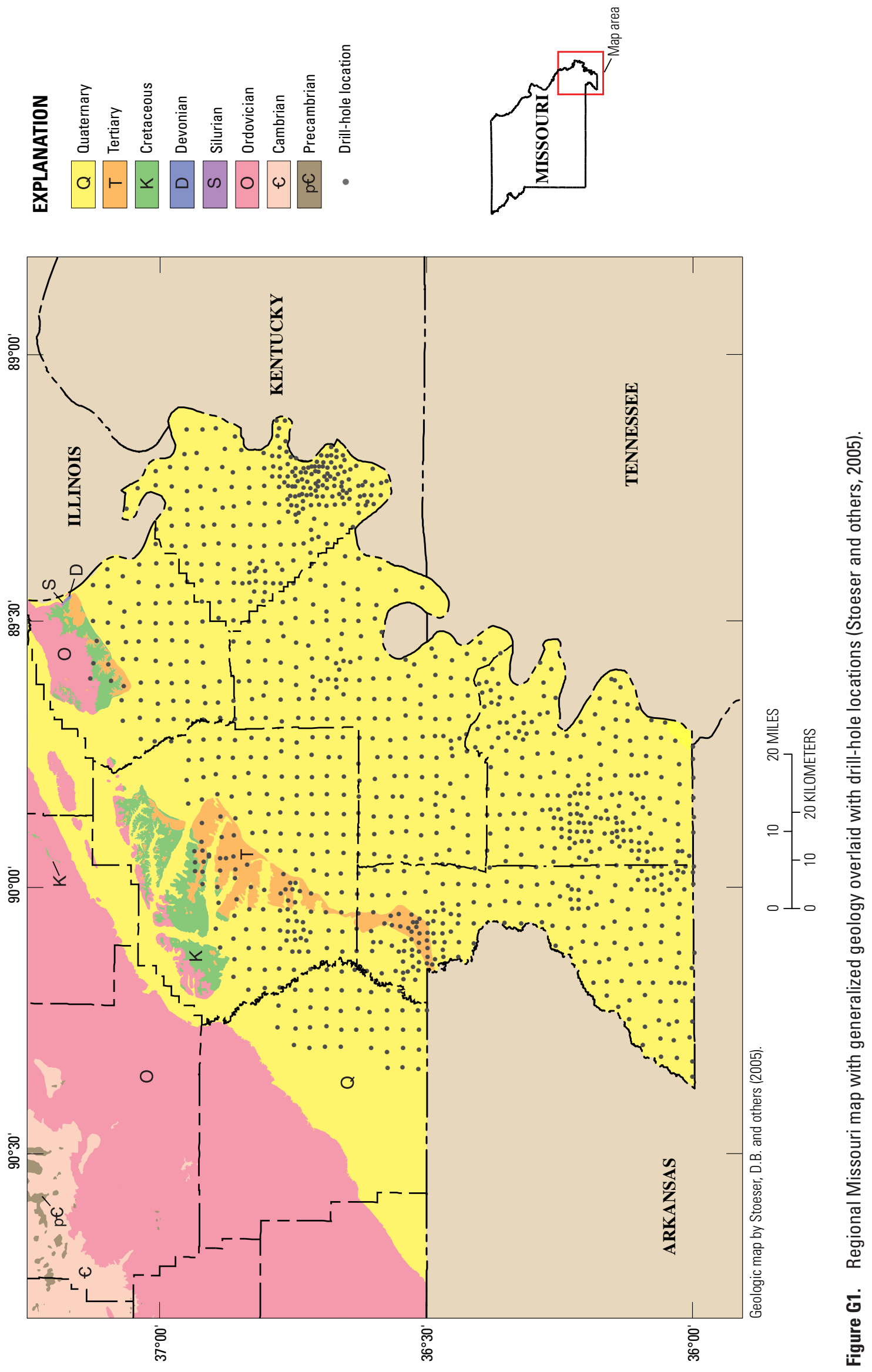

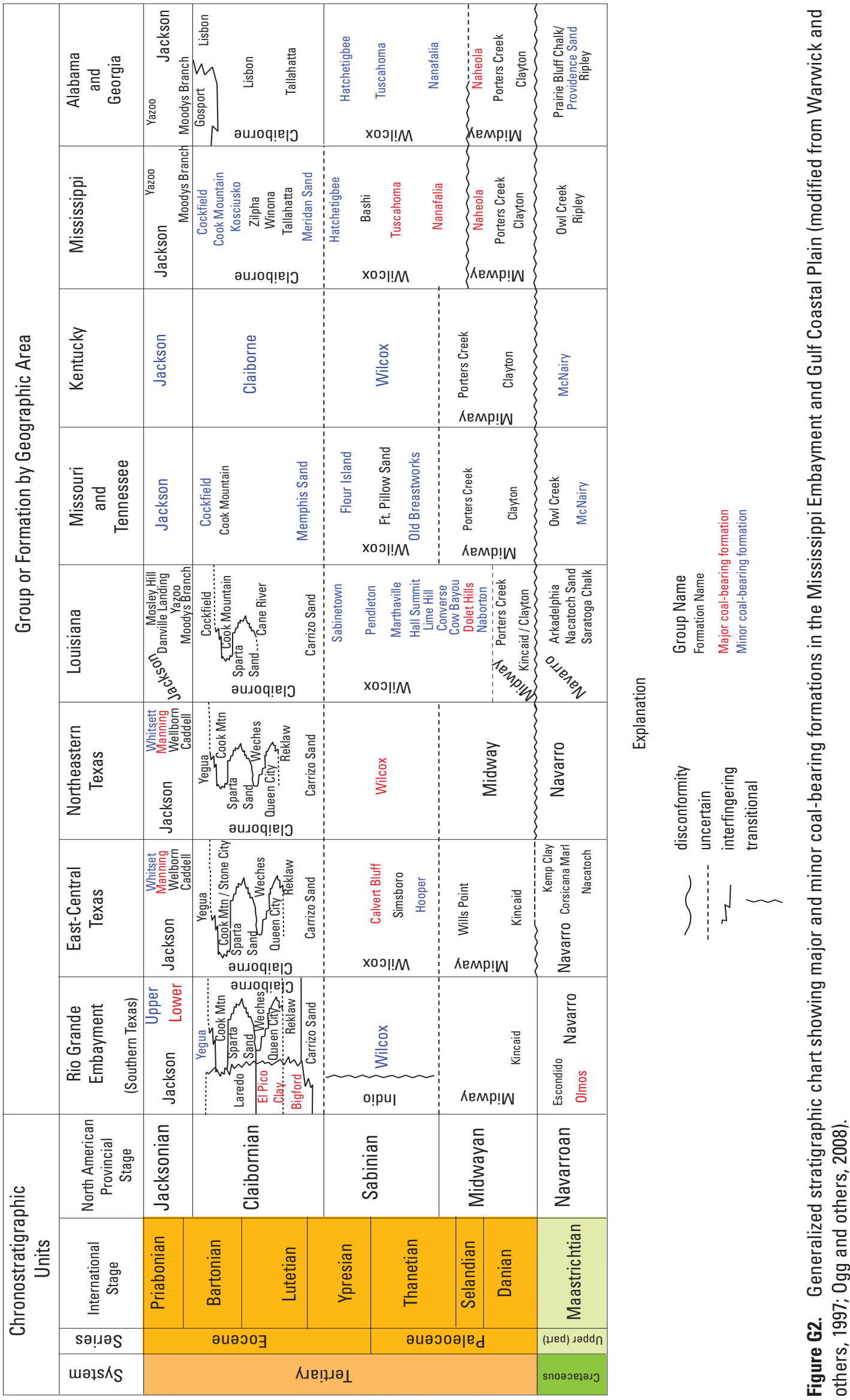


\section{Shallow Coal and Kaolinite Exploration Drill-Hole Data, North Carolina and South Carolina}

By Matthew D. Merrill and Peter D. Warwick

Chapter $\mathrm{H}$ of

Shallow Coal Exploration Drill-Hole Data-Alabama, Georgia, Kentucky, Louisiana, Mississippi, Missouri, North Carolina, South Carolina, Tennessee, and Texas

Edited by Brett J. Valentine and Kristin O. Dennen

Open-File Report 2011-1261-H 
Suggested citation:

Merrill, M.D., and Warwick, P.D., 2012, Shallow coal and Kaolinite exploration drill-hole data, North Carolina and South Carolina, in Valentine, B.J., and Dennen, K.O., eds., Shallow coal exploration drill-hole data-Alabama, Georgia, Kentucky, Louisiana, Mississippi, Missouri, North Carolina, South Carolina, Tennessee, and Texas: U.S. Geological Survey Open-File Report 2011-1261, ch. H, 7 p. plus appendix. (Available online.) 


\section{Contents}

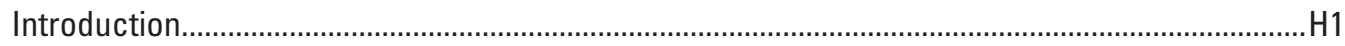

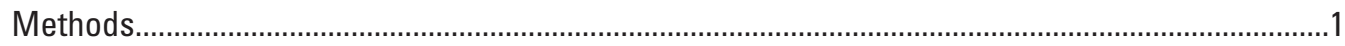

Generalized Coal and Kaolinite Geology of North Carolina and South Carolina..............................1

Data

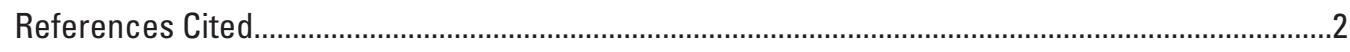

Appendix H1. Shallow Coal Exploration Drill-Hole Data for North Carolina ...................................2

Appendix H2. Shallow Coal Exploration Drill-Hole Data for South Carolina ......................................2

\section{Figures}

H1. North Carolina regional map with county lines showing the North Carolina coal exploration drill-hole locations.......................................................................................H5

H2. South Carolina regional map with county lines showing the South Carolina coal exploration drill-hole locations...................................................................................

H3. Generalized stratigraphic chart of North Carolina and South Carolina upper Cretaceous through Pleistocene formations in the upper Coastal Plain . .7

\section{Tables}

H1. Attribute titles and data descriptions and formats for the North Carolina coal and kaolinite exploration drill-hole dataset.

H2. Attribute titles and data descriptions and formats for the South Carolina coal and kaolinite exploration drill-hole dataset.

H3. Explanation of comments used to describe the North Carolina drill-hole dataset. ...........3

H4. Explanation of comments used to describe the South Carolina drill-hole dataset...........3

H5. North Carolina counties and the number of drill holes by county.....................................

H6. South Carolina counties and the number of drill holes by county.................................... 


\title{
Shallow Coal and Kaolinite Exploration Drill-Hole Data, North Carolina and South Carolina
}

\author{
By Matthew D. Merrill and Peter D. Warwick
}

\section{Introduction}

Coal and kaolinite exploration drill-hole data from 533 and 200 wells in North Carolina and South Carolina, respectively, drilled between November 1978 and June 1979 by Phillips Coal Company, a division of Phillips Petroleum Company (Phillips), are discussed in this chapter, and the data are provided in accompanying spreadsheets. The data are part of a larger dataset donated to the U.S. Geological Survey by the North American Coal Corporation, which purchased Phillips assets in 2001 (see chapter A, this volume). The data in 10 State reports have been digitized from field maps to create unified and spatially consistent coal exploration drill-hole datasets for each of the States (chapters B-K, this volume). Data for North Carolina and South Carolina include maps of each State with drill-hole coverage (figs. H1 and H2), a list of data attributes and explanations of the data format (tables $\mathrm{H} 1$ and $\mathrm{H} 2$ ), a list of comments found in the data and definitions of them (tables $\mathrm{H} 3$ and $\mathrm{H} 4$ ), a list of counties and the number of drill holes for each county (tables H5 and H6), and tabulated data in spreadsheet format (see appendixes H1 and $\mathrm{H} 2$ ).

\section{Methods}

Data from drill-hole tabulation sheets completed by Phillips were entered into spreadsheets. Annotated field and highway maps from Phillips, generally 1:62,500 to 1:100,000 scale, were utilized to spot check the accuracy of the location information in the drill-hole tabulation sheets. Spot checks were made using the appropriate 1927 State coordinate plane projection source material digitized from hardcopy maps into a geographic information system (GIS) using ArcMap ${ }^{\mathrm{TM}}$ software from the Environmental Systems Research Institute, Inc. (ESRI). Fiducial marks served as reference points. Drill-hole locations were digitized and compared to the locations of the points given in the tabulated data sheets. To facilitate combining this dataset with datasets for other States, the drill- hole dataset has been reprojected into a North American Datum of 1983 geographic coordinate system. The shapefile data were exported to a spreadsheet (see appendixes $\mathrm{H} 1$ and $\mathrm{H} 2$ ).

\section{Generalized Coal and Kaolinite Geology of North Carolina and South Carolina}

Upper Cretaceous units in North Carolina and South Carolina contain both lignite and kaolinite (fig. H3). In South Carolina, the Paleocene Sawdust Landing Formation of the Black Mingo Group contains lignite and kaolinite, and the Eocene Huber Formation and an unnamed Miocene unit contain kaolinite (Siesser and others, 1985; Krutak and Beron, 1990; Nystrom and others, 1991; Sohl and Owens, 1991).

\section{Data}

The North Carolina and South Carolina data provide drillhole coverage for the Atlantic Coastal Plain (figs. $\mathrm{H} 1$ and $\mathrm{H} 2$ ). Drill-hole depths range from 10 to 300 feet in North Carolina, with an average depth of 237 feet, and 50 to 310 feet in South Carolina, with an average depth of 240 feet. Exploration data for North Carolina recorded only 14 drill-hole locations (out of a total of 533 drill holes) with coal information and 8 drill holes that were described as having the occurrence of kaolinite; exploration in South Carolina yielded only three locations with coal data (out of a total of 200 drill holes). Comparisons between digitized highway map points and their corresponding drill-hole tabulation sheet coordinates indicate that the drilling team accurately determined their locations from local topographic maps; therefore, there are no spatial errors associated with the creation of this dataset. Shapefile attributes include all original raw data with the exception of the land owner information (tables H1 and H2). The shapefile was exported to spreadsheets (see appendixes $\mathrm{H} 1$ and $\mathrm{H} 2$ ). 


\section{References Cited}

Dicken, C.L., Nicholson, S.W., Horton, J.D., Foose, M.P., and Mueller, J.A.L., 2005, Preliminary integrated geologic map databases for the United States: Alabama, Florida, Georgia, Mississippi, North Carolina, and South Carolina: U.S. Geological Survey Open-File Report 2005-1323, version 1.1.

Krutak, P.R., and Beron Jr., P., 1990, Heterostegina zoneA shallow Anahuac (late Oligocene- - early Miocene) oil frontier in southern Louisiana and Mississippi: Transactions - Gulf Coast Association of Geological Societies, v. 60 , p. 397-409.

Nystrom Jr., P.G., Willoughby, R.H., Price, L.K., 1991, Cretaceous and Tertiary stratigraphy of the Upper Coastal Plain, South Carolina, in Horton, J.W., and Zullo, V.A., eds., The geology of the Carolinas: Carolina Geological Society Fiftieth Anniversary Volume, p. 221-240.

Self-Trail, J.M., Wrege, B.M., Prowell, D.C., Seefelt, E.L, and Weems, R.E., 2004, Preliminary physical stratigraphy and geophysical data of the USGS Elizabethtown core (BL-244/ BL-C-1-2003), Bladen County, North Carolina: U.S. Geological Survey Open-File Report 2004-1301, 26 p.
Siesser, W.G., Fitzgerald, B.G., Kronman, D.J., 1985, Correlation of Gulf Coast provincial Paleogene stages with European standard stages: Geological Society of America Bulletin, v. 96, p. 827-831.

Sohl, N.F., and Owens, J.P., 1991, Cretaceous stratigraphy of the Carolina Coastal Plain, in Horton, J.W., and Zullo, V.A., eds., The geology of the Carolinas: Carolina Geological Society Fiftieth Anniversary Volume, p. 191-220.

\section{Appendix H1}

The North Carolina coal exploration drill-hole dataset in spreadsheet format is available at pubs.usgs.gov/of/2011/1261/ Appendices/H1-NC.xls.

\section{Appendix H2}

The South Carolina coal exploration drill-hole dataset in spreadsheet format is available at pubs.usgs.gov/of/2011/1261/ Appendices/H2-SC.xls.

Table H1. Attribute titles and data descriptions and formats for the North Carolina coal and kaolinite exploration drill-hole dataset.

\begin{tabular}{ll}
\hline \multicolumn{1}{c}{ Attribute title } & \multicolumn{1}{c}{ Data description and format } \\
\hline DRILL-HOLE NAME & Two-letter county code followed by drill-hole number. \\
COUNTY & County where the drill hole is located. \\
ELEVATION & Elevation above sea level in feet. \\
DEPTH_TOTAL & Depth of drill hole in feet. \\
DEPTH_PROBED & Depth of geophysical probe measurement in feet. \\
LATITUDE & Decimal degree location values given to 4 decimal places. \\
LONGITUDE & Decimal degree location values given to 4 decimal places. \\
X_C & Thickness of coal for bed number $\mathrm{X}$ in decimal feet. \\
X_CP & Thickness of coal and partings combined for bed number $\mathrm{X}$ in decimal feet. \\
X_DEPTH & Top depth of bed number $\mathrm{X}$ in feet. \\
K_THICKNESS & Thickness of kaolinite for bed number $\mathrm{X}$ in decimal feet. \\
K_DEPTH & Depth of kaolinite for bed number $\mathrm{X}$ in feet. \\
COMMENT & Additional information regarding the drill hole. \\
\hline
\end{tabular}


Table H2. Attribute titles and data descriptions and formats for the South Carolina coal and kaolinite exploration drill-hole dataset.

\begin{tabular}{ll}
\hline \multicolumn{1}{c}{ Attribute title } & \multicolumn{1}{c}{ Data description and format } \\
\hline DRILL-HOLE NAME & Two-letter count code followed by drill-hole number. \\
COUNTY & County where the drill hole is located. \\
ELEVATION & Elevation above sea level in feet. \\
DEPTH_TOTAL & Depth of drill hole in feet. \\
DEPTH_PROBED & Depth of geophysical probe measurement in feet. \\
LATITUDE & Decimal degree location values given to 4 decimal places. \\
LONGITUDE & Decimal degree location values given to 4 decimal places. \\
X_C & Thickness of coal for bed number $\mathrm{X}$ in decimal feet. \\
X_CP & Thickness of coal and partings combined for bed number $\mathrm{X}$ in decimal feet. \\
X_DEPTH & Top depth of bed number $\mathrm{X}$ in feet. \\
COMMENT & Additional information regarding the drill hole. \\
\hline
\end{tabular}

Table H3. Explanation of comments used to describe the North Carolina drill-hole dataset (modified from J.A. Luppens, U.S. Geological Survey, written commun., 2009).

\begin{tabular}{|c|c|}
\hline Symbol/Comment & Description \\
\hline ? & Questionable data/information. \\
\hline HUNG PROBE (150') & $\begin{array}{l}\text { During exploration the geophysical logging instrument were stuck in the drill hole at } 150 \text { feet. Due to this } \\
\text { issue no geophysical data were recovered for this drill hole. }\end{array}$ \\
\hline KAOLINITE CORED & $\begin{array}{l}\text { During exploration a kaolinte deposit was encountered and a core sample was taken. The depth of the } \\
\text { core is listed in the comment section after the notation. }\end{array}$ \\
\hline NC & Abbreviation for "no coal." No coal was found during exploration for this drill hole. \\
\hline NK & Abbreviation for “no kaolinite.” No kaolinite was found during exploration for this drill hole. \\
\hline NO ELEVATION RECORDED & No ground elevation information was recorded on the original coal exploration maps for this drill hole. \\
\hline NP & Abbreviation for “not probed.” Geophysical logging never occurred at this location. \\
\hline NSL & $\begin{array}{l}\text { Abbreviation for "no significant lignite." Coal may have been found during exploration but because the } \\
\text { coal beds were thin (usually less than } 2 \text { feet thick) no coal data were recorded. }\end{array}$ \\
\hline POOR & A subjective term used to describe coal of poor quality. \\
\hline
\end{tabular}

Table H4. Explanation of comments used to describe the South Carolina drill-hole dataset (modified from J.A. Luppens, U.S. Geological Survey, written commun., 2009).

\begin{tabular}{ll}
\hline \multicolumn{1}{c}{ Symbol/Comment } & Description \\
\hline NC & Abbreviation for "no coal." No coal was found during exploration for this drill hole. \\
NSL & $\begin{array}{c}\text { Abbreviation for "no significant lignite." Coal may have been found during exploration but because the } \\
\text { coal beds were thin (usually less than 2 feet thick) no coal data were recorded. }\end{array}$ \\
POOR & A subjective term used to describe coal of poor quality. \\
\hline
\end{tabular}


H4 Shallow Coal Exploration Drill-Hole Data-AL GA, KY, LA, MS, MO, NC, SC, TN, TX

Table H5. North Carolina counties and the number of drill holes by county.

\begin{tabular}{lc}
\hline \multicolumn{1}{c}{ County } & Number of drill holes \\
\hline Bladen & 33 \\
Cumberland & 24 \\
Greene & 38 \\
Harnett & 4 \\
Hoke & 11 \\
Johnston & 23 \\
Lenoir & 24 \\
Pitt & 47 \\
Robeson & 69 \\
Sampson & 99 \\
Wayne & 161 \\
\multicolumn{1}{c}{ Total } & 533 \\
\hline
\end{tabular}

Table H6. South Carolina counties and the number of drill holes by county.

\begin{tabular}{lc}
\hline \multicolumn{1}{c}{ County } & Number of drill holes \\
\hline Berkely & 27 \\
Clarendon & 75 \\
Darlington & 15 \\
Florence & 8 \\
Lee & 9 \\
Sumter & 27 \\
Williamsburg & 39 \\
$\quad$ Total & 200
\end{tabular}




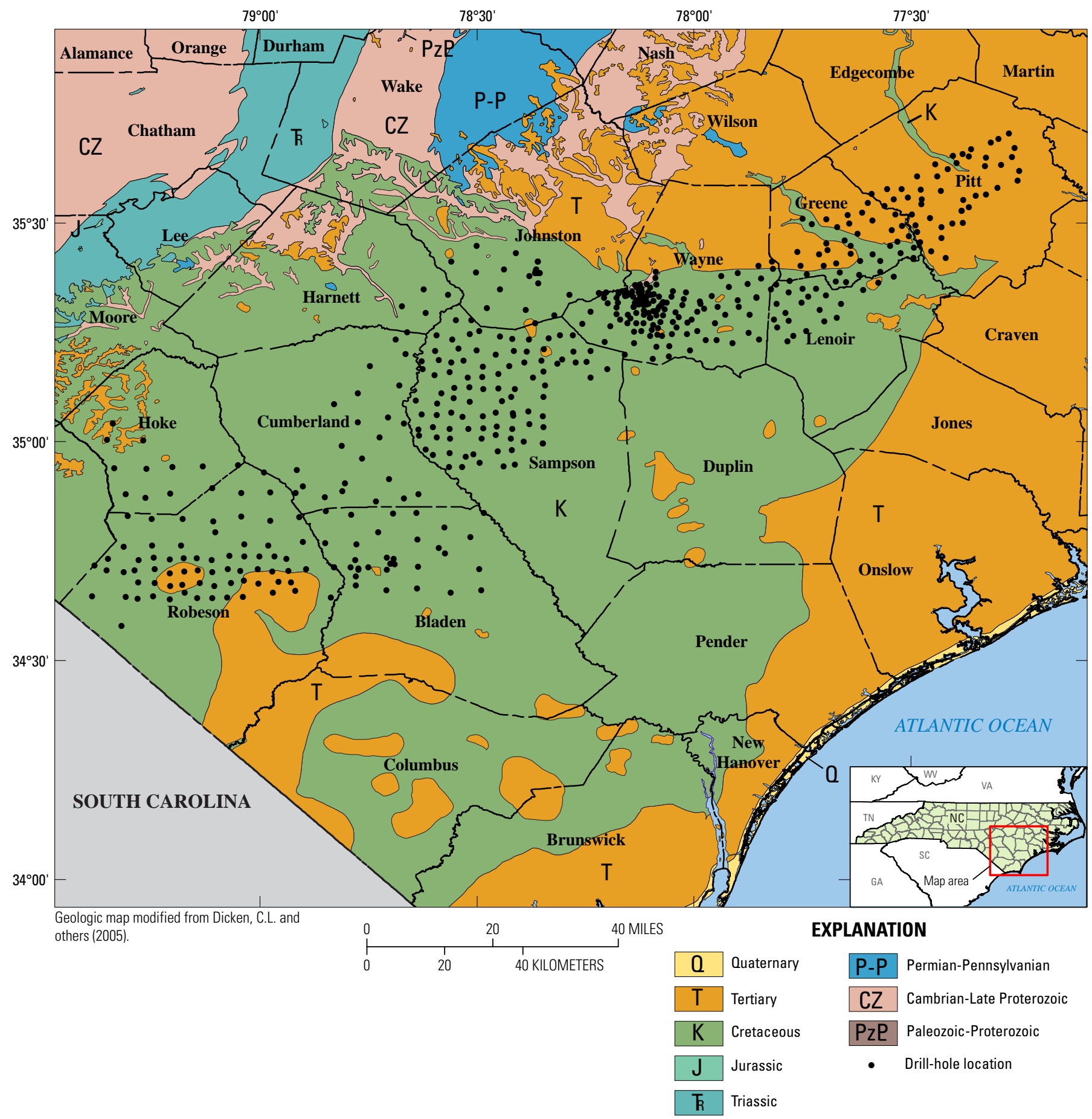

Figure H1. North Carolina regional map with county lines showing the North Carolina coal exploration drill-hole locations (geologic map modified from Dicken, C.L. and others, 2005). 


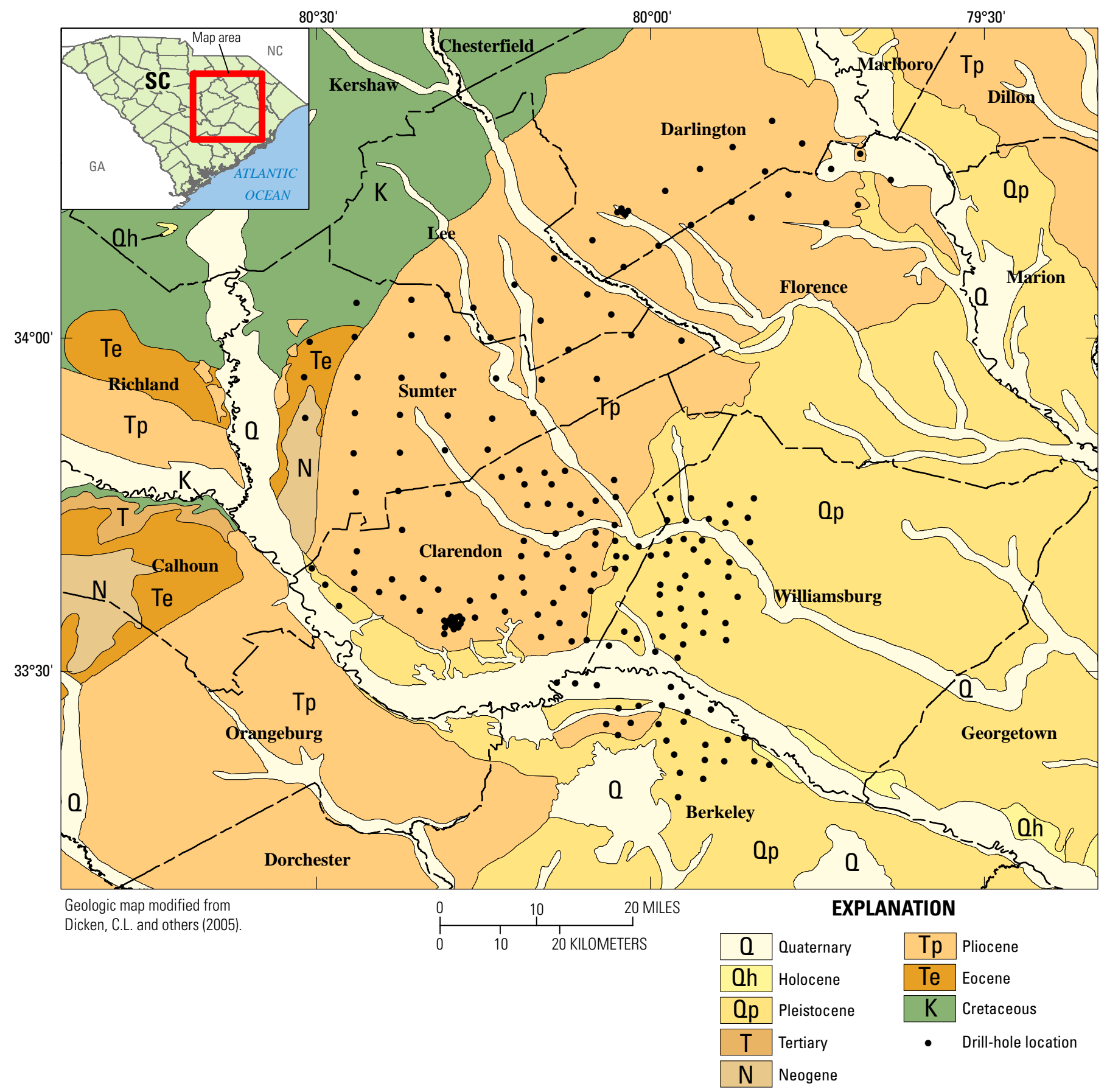

Figure H2. South Carolina regional map with county lines showing the South Carolina coal exploration drill-hole locations (geologic map modified from Dicken, C.L. and others, 2005). 


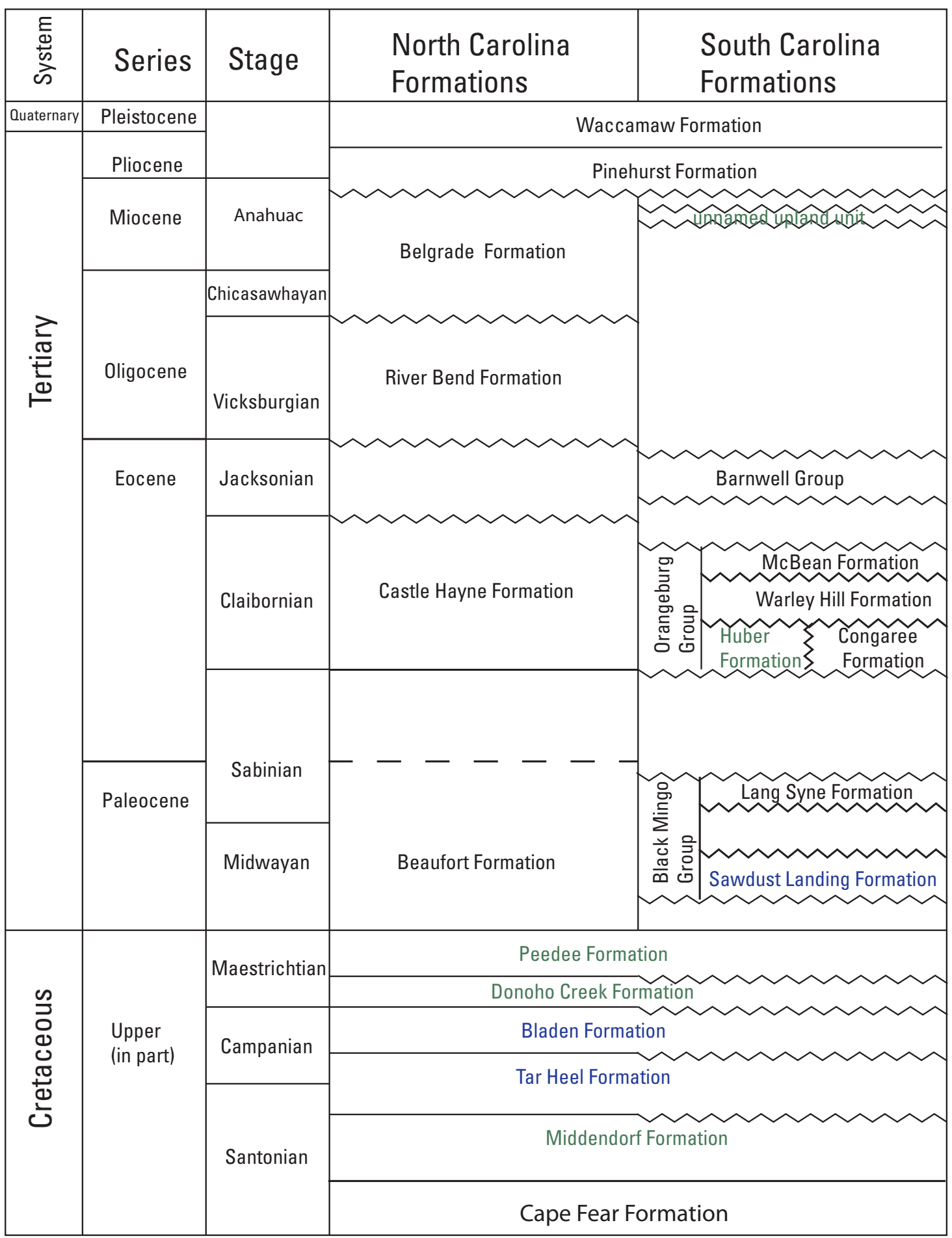

$\begin{array}{lll} & \text { Uncomformable } & \text { Lignite- and kaolinite-bearing formation } \\ \text { Transitional Unsure } & \text { Kaolinite-bearing formation }\end{array}$

Figure H3. Generalized stratigraphic chart of North Carolina and South Carolina upper Cretaceous through Pleistocene formations in the upper Coastal Plain (Siesser and others, 1985; Krutak and Beron, 1990; Nystrom and others, 1991; Sohl and Owens, 1991; Self-Trail and others, 2004). 


\section{Shallow Coal Exploration Drill-Hole Data, Western Tennessee}

By Krystina R. Scott-Sanchez, Brett J. Valentine, and Peter D. Warwick

Chapter I of

Shallow Coal Exploration Drill-Hole Data-Alabama, Georgia, Kentucky, Louisiana, Mississippi, Missouri, North Carolina, South Carolina, Tennessee, and Texas

Edited by Brett J. Valentine and Kristin O. Dennen

Open-File Report 2011-1261-I 
Suggested citation:

Scott-Sanchez, K.R., Valentine, B.J., and Warwick, P.D., 2012, Shallow coal exploration drill-hole data, western Tennessee, in Valentine, B.J., and Dennen, K.O., eds., Shallow coal exploration drill-hole data—Alabama, Georgia, Kentucky, Louisiana, Mississippi, Missouri, North Carolina, South Carolina, Tennessee, and Texas: U.S. Geological Survey Open-File Report 2011-1261, ch. I, 5 p. plus appendix. (Available online.) 


\section{Contents}

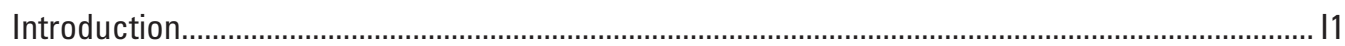

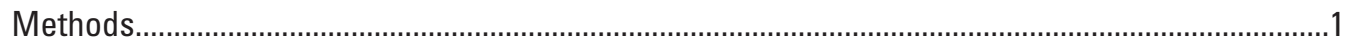

Generalized Coal Geology of Western Tennessee ..............................................................................

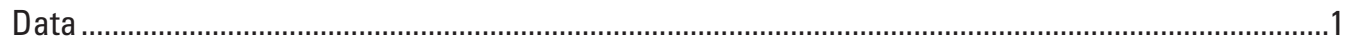

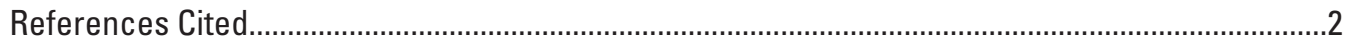

Appendix 11. Shallow Coal Exploration Drill-Hole Data for Western Tennessee ...............................2

\section{Figures}

11. Regional geologic map of western Tennessee with county boundaries overlaid with drill-hole locations from the western Tennessee coal exploration drill-hole

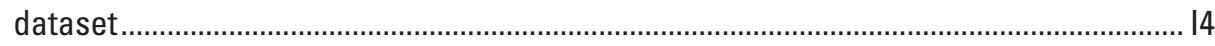

12. Cross section of the Mississippi Embayment ....................................................................

13. Generalized stratigraphic chart showing major and minor coal-bearing formations in the Mississippi Embayment and Gulf Coastal Plain

\section{Tables}

11. Attribute titles and data descriptions and formats for the western Tennessee drill-hole dataset. 12

12. Explanation of comments used to describe the western Tennessee drill-hole dataset. 3

13. Western Tennessee counties and the number of drill holes by county. ............................ 


\title{
Shallow Coal Exploration Drill-Hole Data, Western Tennessee
}

\author{
By Krystina R. Scott-Sanchez, Brett J. Valentine, and Peter D. Warwick
}

\section{Introduction}

Coal exploration drill-hole data from 2,390 wells covering 18 counties in western Tennessee drilled between 1970 and 1977 by Phillips Coal Company, a division of Phillips Petroleum Company (Phillips), are discussed in this chapter, and the data are provided in an accompanying spreadsheet. The data are part of a nationwide dataset donated to the U.S. Geological Survey (USGS) by the North American Coal Corporation in 2001 (see chapter A, this volume). The data were digitized from field maps to create unified and spatially consistent coal exploration drill-hole datasets for each of the States in the donation (chapters B-K, this volume). Data for western Tennessee include a geologic map of the State with drill-hole coverage (fig. I1), a list of data attributes and explanations of the data format (table I1), a list of comments found in the data and their explanations (table I2), a list of counties and the number of drill holes for each county (table I3), and tabulated data in spreadsheet format (see appendix I1).

\section{Methods}

Hardcopy Phillips exploration maps, in western Tennessee 1927 State coordinate plane projection, were scanned and digitized into a geographic information system (GIS) using ArcMap ${ }^{\mathrm{TM}}$ software from the Environmental Systems Research Institute, Inc. (ESRI). Roads and county boundaries served as reference points to georeference the scanned exploration maps. Coal data attributes (table I1) were populated using the information contained on the exploration maps. Comments have been added by USGS staff if there were problems or uncertainties during compiling or if any additional information on the maps needed to be described (table I2). The dataset was projected into a North American Datum of 1983 geographic coordinate system to facilitate combining the dataset with similar Phillips datasets published by the USGS for other States. The data attributes were exported from the GIS to a spreadsheet (see appendix I1).

\section{Generalized Coal Geology of Western Tennessee}

Western Tennessee (fig. I1) is part of the Mississippi Embayment structure (fig. I2), which is a syncline filled with several thousands of feet of Upper Cretaceous to Upper Eocene marine and deltaic sediments locally overlain by Pliocene and Quaternary fluvial deposits of the Mississippi River (Cox and Van Arsdale, 2002). Lignite beds and lignitic clays occur as discontinuous lenses in sediments of the Paleogene Wilcox Group, Claiborne Group, Jackson Formation, and less frequently in the Upper Cretaceous McNairy Formation (fig. I3) (Hackley and others, 2006; Parks, 1981). These lignite deposits are part of the Gulf Coastal Plain Coal Province (Hackley and others, 2006).

\section{Data}

The western Tennessee drill-hole dataset contains coal exploration information for 2,390 drill-hole locations within 18 counties in the Gulf Coast region. Geophysical instruments were used on a total of 419 drill holes with probe depths ranging from 63 to 300 feet, while the remaining 1,971 drill holes were assigned a probed depth value of 0 feet due to unrecorded probe depths on the original maps. The densest drill-hole coverage is found in the center of western Tennessee in Lauderdale, Dyer, Crockett, and Gibson Counties, which include 40 percent of the total data (table I3). Due to the generalized nature of the original highway maps that contained the drill-hole information and the process of georeferencing these maps to a new base layer, we expect the location error to be \pm 0.25 mile. 


\section{References Cited}

Cox, R.T., and Van Arsdale, R.B., 2002, The Mississippi Embayment, North America-A first order continental structure generated by the Cretaceous super plume mantle event: Journal of Geodynamics, v. 34, p. 163-176.

Hackley, P.C., Warwick, P.D., Thomas, R.E., and Nichols, D.J., 2006, Review of lignite resources of western Tennessee and the Jackson Purchase Area, western Kentucky: U.S. Geological Survey Open-File Report 2006-1078, 34 p., accessed August 2, 2011, at pubs.usgs. gov/of/2006/1078/.

Nicholson, S.W., Dicken, C.L., Horton, J.D., Labay, K.A., Foose, M.P., and Mueller, J.A.L., 2005, Preliminary integrated geologic map databases for the United StatesKentucky, Ohio, Tennessee, and West Virginia: U.S. Geological Survey Open-File Report 2005-1324, Version 1.1 (updated December 2007), at pubs.usgs.gov/of/2005/1324.
Ogg, J.G., Ogg, Gabi, and Gradstein, F.M., 2008, The concise geologic time scale: Cambridge, U.K., Cambridge University Press, 184 p.

Parks, W.S., 1981, Appraisal of hydrologic information needed in anticipation of lignite mining in Lauderdale County, Tennessee: U.S. Geological Survey Water-Resources Investigations Report 80-54, 67 p.

Warwick, P.D., SanFilipo, J.R., Crowley, S.S., Thomas, R.E., and Freid, J., comps., and Tully, J.K., digital comp., 1997, Map showing outcrop of the coal-bearing units and land use in the Gulf Coast coal region: U.S. Geological Survey Open-File Report 97-172, 1 sheet, accessed April 20, 2011, at pubs.usgs.gov/of/1997/of97-172/.

\section{Appendix I1}

The western Tennessee coal exploration drill-hole dataset in spreadsheet format is available at pubs.usgs.gov/ of/2011/1261/Appendices/I1-TN.xls.

Table I1. Attribute titles and data descriptions and formats for the western Tennessee drill-hole dataset.

\begin{tabular}{ll}
\hline \multicolumn{1}{c}{ Attribute title } & \multicolumn{1}{c}{ Data description and format } \\
\hline DRILL-HOLE NAME & Two-letter county code followed by drill-hole number. \\
COUNTY & The county where the drill hole was located. \\
ELEVATION & Elevation above sea level in feet. \\
DEPTH_TOTAL & Depth of drill hole in feet. \\
DEPTH_PROBED & Depth of geophysical probe measurement in feet. \\
LATITUDE & Decimal degree location values given to 4 decimal places. \\
LONGITUDE & Decimal degree location values given to 4 decimal places. \\
COMMENT & Additional information regarding the entire drill hole. \\
X_C & Thickness of coal for bed number X in decimal feet. \\
X_CP & Thickness of coal and partings combined for bed number X in decimal feet. \\
X_DEPTH & Top depth of bed number $X$ in feet. \\
X_BED & A number or letter assigned to different coal beds of the same drill hole, which is not correlated through- \\
& out the dataset. \\
X_COMMENT & Additional information regarding coal bed $X$. \\
\hline
\end{tabular}


Table 12. Explanation of comments used to describe the western Tennessee drill-hole dataset (J.A. Luppens, U.S. Geological Survey, written communication, 2009).

\begin{tabular}{ll}
\hline \multicolumn{1}{c}{ Comment } & \multicolumn{1}{c}{ Explanation } \\
\hline BED DEPTH NOT RECORDED & No coal-bed depth information was recorded for this coal bed. \\
I & Abbreviation for inferior. Subjective term used to describe poor coal quality. \\
NC & Abbreviation for "no coal.” No coal was found during exploration for this drill hole. \\
NC/CLAY & No coal was found during exploration, but a kaolinitic clay deposit was found during drilling. \\
NO DATA RECORDED & No data were recorded on original coal exploration maps for this drill hole. \\
NO ELEVATION RECORDED & No ground elevation information was recorded on the original coal exploration maps for this drill hole. \\
NP & Abbreviation for "not probed.” Geophysical logging never occurred at this location. \\
& Abbreviation for "no significant lignite." Coal may have been found during exploration but because the \\
NSL & coal beds were thin (usually less than 2 feet thick) no coal data were recorded. \\
PI & Abbreviation for "partially inferior." Used to describe that a portion of the coal bed is of a low quality. \\
\hline
\end{tabular}

Table 13. Western Tennessee counties and the number of drill holes by county.

\begin{tabular}{|c|c|}
\hline County & Number of drill holes \\
\hline Benton & 1 \\
\hline Chester & 9 \\
\hline Crocket & 124 \\
\hline Carroll & 3 \\
\hline Dyer & 208 \\
\hline Fayette & 122 \\
\hline Gibson & 144 \\
\hline Hardeman & 204 \\
\hline Haywood & 181 \\
\hline Henry & 100 \\
\hline Lauderdale & 501 \\
\hline Lake & 39 \\
\hline Madison & 42 \\
\hline Mississippi & 2 \\
\hline Obion & 267 \\
\hline Shelby & 54 \\
\hline Tipton & 170 \\
\hline Weakley & 219 \\
\hline Total & 2,390 \\
\hline
\end{tabular}




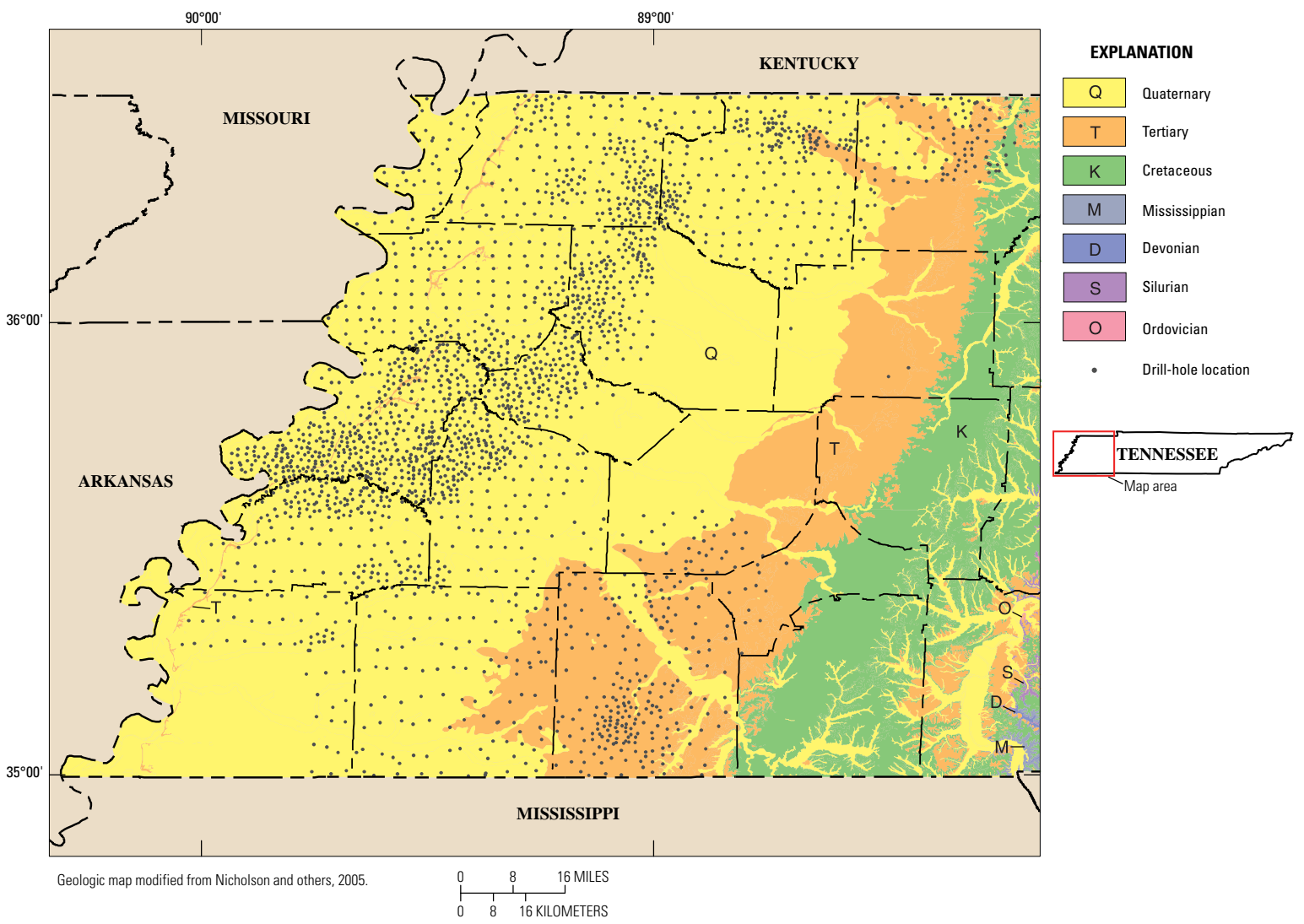

Figure 11. Regional geologic map of western Tennessee with county boundaries overlaid with drill-hole locations from the western Tennessee coal exploration drill-hole dataset (geologic map modified from Nicholson and others, 2005).

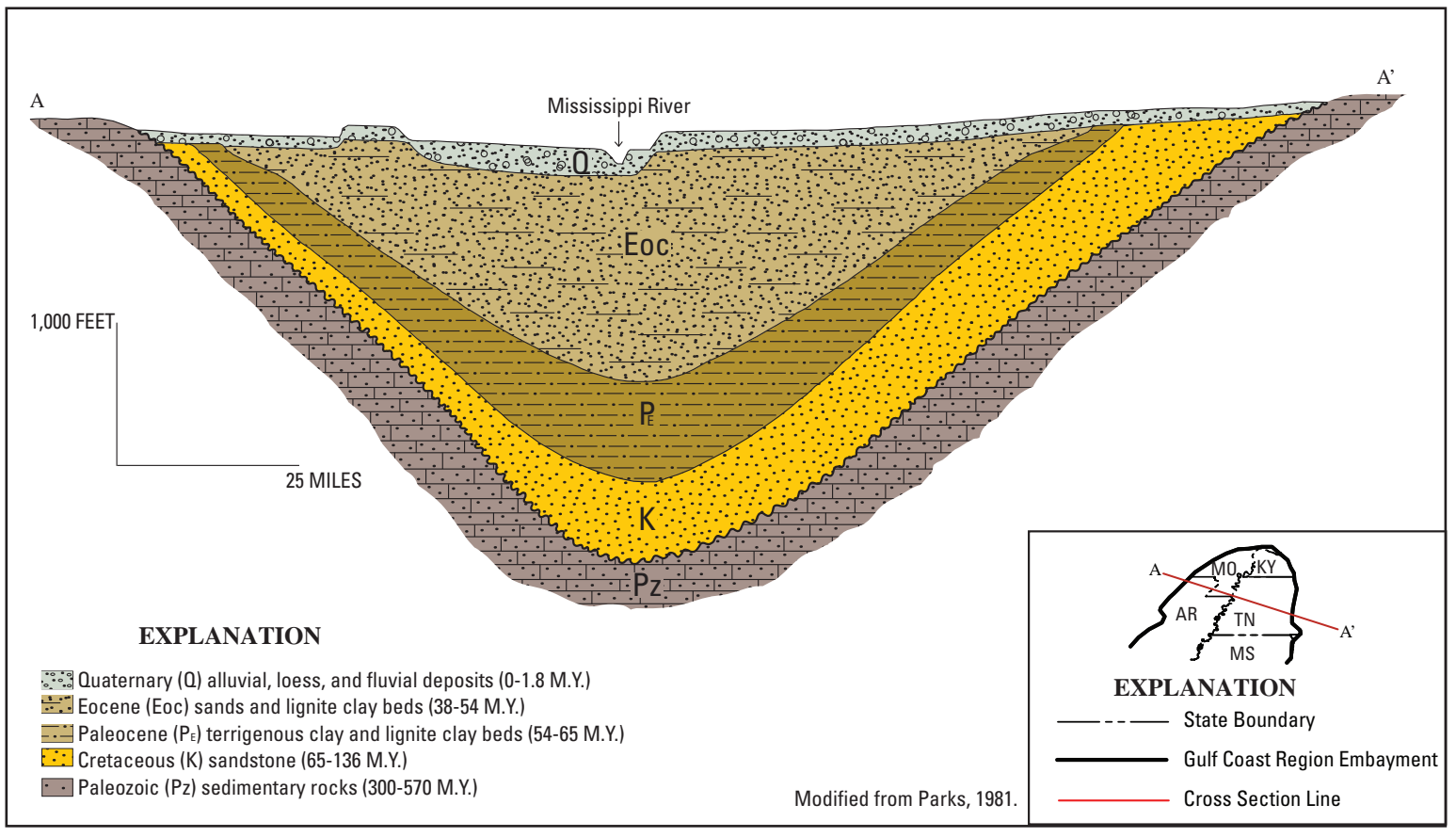

Figure 12. Cross section of the Mississippi Embayment (modified from Parks, 1981). 

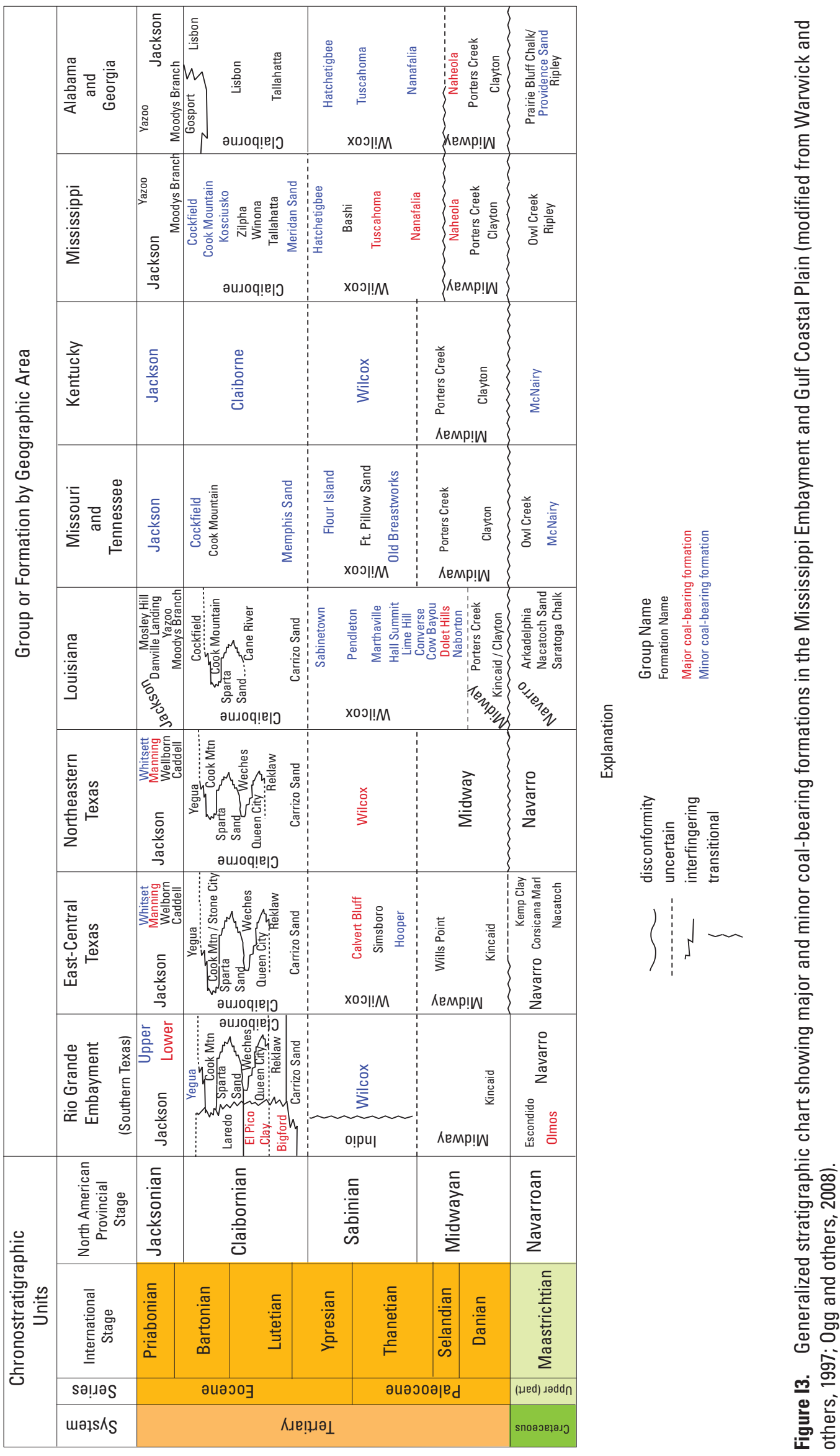


\section{Shallow Coal Exploration Drill-Hole Data, Northeast Texas}

By Rachel M. Gesserman, Matthew D. Merrill, and Peter D. Warwick

Chapter J of

Shallow Coal Exploration Drill-Hole Data-Alabama, Georgia, Kentucky, Louisiana, Mississippi, Missouri, North Carolina, South Carolina, Tennessee, and Texas

Edited by Brett J. Valentine and Kristin O. Dennen

Open-File Report 2011-1261-J 
Suggested citation:

Gesserman, R.M., Merrill, M.D., and Warwick, P.D., 2012, Shallow coal exploration drill-hole data, northeast Texas in Valentine, B.J., and Dennen, K.O., eds., Shallow coal exploration drill-hole data-Alabama, Georgia, Kentucky, Louisiana, Mississippi, Missouri, North Carolina, South Carolina, Tennessee, and Texas: U.S. Geological Survey OpenFile Report 2011-1261, ch. J, 8 p. plus appendix. (Available online.) 


\section{Contents}

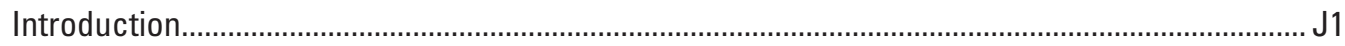

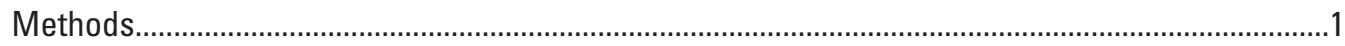

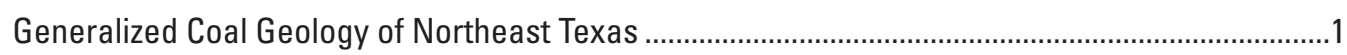

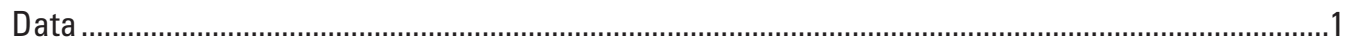

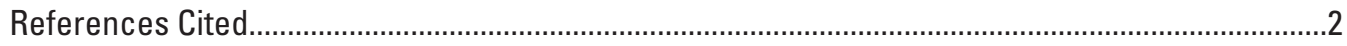

Appendix J1. Shallow Coal Exploration Drill-Hole Data for Northeast Texas....................................2

\section{Figures}

J1. Geology of northeast Texas with drill-hole locations ....................................................J6

J2. Geology and structure of northeast Texas ......................................................................

J3. Generalized stratigraphic chart showing major and minor coal-bearing formations in the Mississippi Embayment and Gulf Coastal Plain ....................................8

\section{Tables}

J1. Attribute titles and data descriptions and formats for the northeast Texas drill-hole dataset............................................................................................................. J3

J2. Explanation of comments used to describe the northeast Texas drill-hole

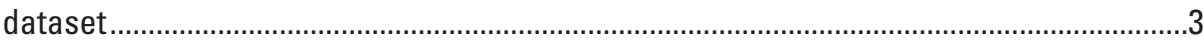

J3. Northeast Texas counties and the number of drill holes by county..................................5 


\title{
Shallow Coal Exploration Drill-Hole Data, Northeast Texas
}

\author{
By Rachel M. Gesserman, Matthew D. Merrill, and Peter D. Warwick
}

\section{Introduction}

Coal exploration drill-hole data from 8,010 wells in northeast Texas drilled between 1977 and 1982 by Phillips Coal Company, a division of Phillips Petroleum Company (Phillips), are discussed in this chapter, and the data are provided in an accompanying spreadsheet. The data are part of a larger dataset donated to the U.S. Geological Survey (USGS) by the North American Coal Corporation, which purchased Phillips assets in 2001 (see chapter A, this volume). The data in 10 State reports have been digitized from field maps to create unified and spatially consistent coal exploration drill-hole datasets for each of the States in the donation (chapters B-K, this volume). Data for northeast Texas include a geologic map of the State with drill-hole coverage (fig. J1), a list of data attributes and explanations of the data format (table J1), a list of comments found in the data and descriptions of them (table J2), a list of counties and the number of drill holes for each county (table J3), and tabulated data in spreadsheet format (see appendix J1).

\section{Methods}

Hardcopy Phillips exploration maps, in Texas North Central 1927 State coordinate plane projection, were digitized into a geographic information system using ArcMap ${ }^{\mathrm{TM}}$ software from the Environmental Systems Research Institute, Inc. (ESRI). Roads and county boundaries served as reference points to georeference scanned maps. Shapefile attribute values were populated with data from drill-hole locations in 16 counties in northeast Texas (fig. J1, table J3). All raw data from the Phillips maps were entered into the shapefile attributes, as well as various comments, abbreviations, and symbols that were used to denote information about the drilled wells (table J1 and table J2). Some changes to the original data were made to maintain uniformity throughout the digitized maps. The dataset was projected into a North American Datum of 1983 geographic coordinate system to facilitate combining the dataset with similar Phillips datasets published by the USGS for other States. The shapefile was exported to a spreadsheet (see appendix J1).

\section{Generalized Coal Geology of Northeast Texas}

The undivided Paleocene to Eocene Wilcox Group crops out in northeast Texas and is overlain by the Eocene Claiborne Group in the East Texas Basin (Warwick and others, 2002). Correlations between these geologic units in other parts of Texas and Louisiana can be seen in figure J3. Structurally, the Mount Enterprise Fault Zone extends to southern Panola County (fig. J2) and divides the study area into westward dipping strata north of the fault zone and steeper, southward dipping strata south of the fault zone (Kaiser, 1990). To the east in the Sabine Uplift area (fig. J2), Wilcox sediment that was derived from the Ouachita Mountains of Oklahoma and Arkansas is represented in a progradational deltaic depositional system in the lower parts of the group, while the upper Wilcox sediments are characteristic of aggradational fluvial sedimentation (Kaiser, 1990). Lignite occurs throughout the Wilcox Group, but in Texas it is most commonly found in the upper two-thirds of the formation (Kaiser and others, 1980). In Louisiana, lignite is most commonly found in the lower Wilcox (Warwick and others, 2008).

The Claiborne Group represents a cycle of marine transgressions and regressions, marked by alternating marine clays and silts with nonmarine, nearshore blanket sands (Eargle, 1968). Surficial formations in the Claiborne Group include the Carrizo Sand, Reklaw Formation, Queen City Sand, Weches Formation, and Sparta Sand (Warwick and others, 2002) (fig. J2).

\section{Data}

The northeast Texas drill-hole dataset contains coal exploration information for 8,010 drill-hole locations in 16 counties in the Gulf Coast region (fig. J1, table J3). Geophysical instruments were used to log a total of 6,836 drill holes and had depths ranging from 54 to 1,000 feet with an average depth of 259 feet. The remaining 1,174 drill holes did not have any probe depth information and were assigned a value of 0 feet. For drill holes that had coal data, the average thickness range of beds, including partings, was 2.04 feet. 
The densest drill-hole coverage is found in Hopkins, Rusk, and Harrison Counties, which contain 66 percent of the data plotted. Location error is expected to be \pm 0.25 mile due to the generalized nature of the original maps and the process of georeferencing a new base layer.

\section{References Cited}

Eargle, D.H., 1968, Nomenclature of formations of Claiborne Group, Middle Eocene coastal plain of Texas, in Contributions to general geology, 1967: U.S. Geological Survey Bulletin 1251-D, p. D1-D25.

Kaiser, W.R., 1990, The Wilcox Group (Paleocene-Eocene) in the Sabine Uplift area, Texas-Depositional systems and deep-basin lignite: The University of Texas at Austin, Bureau of Economic Geology, 20 p.

Kaiser, W.R., Ayers, W.B., Jr., and La Brie, L.W., 1980, Lignite resources in Texas: The University of Texas at Austin, Bureau of Economic Geology Report of Investigations No. 104, 52 p.

Ogg, J.G., Ogg, Gabi, and Gradstein, F.M., 2008, The concise geologic time scale: Cambridge, U.K., Cambridge University Press, $184 \mathrm{p}$.

Stoeser, D.B., Green, G.N., Morath, L.C., Heran, W.D., Wilson, A.B., Moore, D.W., and Van Gosen, B.S., 2005, Preliminary integrated geologic map databases for the United States; central states-Montana, Wyoming, Colorado, New Mexico, North Dakota, South Dakota, Nebraska, Kansas, Oklahoma, Texas, Iowa, Missouri, Arkansas, and Louisiana: U.S. Geological Survey Open-File Report 2005-1351, version 1.2 (updated December 2007) on-line only, accessed August 4, 2011, at pubs.usgs.gov/ of/2005/1351/.
Warwick, P.D., SanFilipo, J.R., Crowley, S.S., Thomas, R.E., and Freid, J., comps., and Tully, J.K., digital comp., 1997, Map showing outcrop of the coal-bearing units and land use in the Gulf Coast coal region: U.S. Geological Survey Open-File Report 97-172, 1 sheet, accessed April 20, 2011, at pubs.usgs.gov/of/1997/of97-172/.

Warwick, P.D., Aubourg, C.E., Suitt, S.E., Podwysocki, S.M., and Schultz, A.C., 2002, Preliminary evaluation of the coal resources for part of the Wilcox Group (Paleocene-Eocene), central Texas: U.S. Geological Survey Open-File Report 02-359, 80 p., accessed August 4, 2011, at pubs.usgs.gov/ of/2002/of02-359/.

Warwick, P.D., Breland, F.C., Jr., and Hackley, P.C., 2008, Biogenic origin of coalbed gas in the northern Gulf of Mexico coastal plain, USA: International Journal of Coal Geology, v. 76, p. 119-137.

\section{Appendix J1}

The northeast Texas coal exploration drill-hole dataset in spreadsheet format is available at pubs.usgs.gov/of/2011/1261/ Appendices/J1-TX.xls. 
Table J1. Attribute titles and data descriptions and formats for the northeast Texas drill-hole dataset.

\begin{tabular}{ll}
\hline \multicolumn{1}{c}{ Attribute title } & \multicolumn{1}{c}{ Data description and format } \\
\hline DRILL-HOLE NAME & County code followed by drill-hole number. \\
COUNTY & County where the drill hole is located. \\
ELEVATION & Elevation above sea level in feet. \\
DEPTH_TOTAL & Depth of drill hole in feet. \\
DEPTH_PROBED & Depth of geophysical probe measurement in feet. \\
LATITUDE & Decimal degree location values given to 4 decimal places. \\
LONGITUDE & Decimal degree location values given to 4 decimal places. \\
COMMENT & Additional information regarding the entire drill hole. \\
X_C & Thickness of coal for bed number $X$ in decimal feet. \\
X_CP & Thickness of coal and partings combined for bed number X in decimal feet. \\
X_DEPTH & Top depth of bed number X in feet. \\
X_BED & A number or letter assigned to different coal beds of the same drill hole, which is not correlated through- \\
& out the dataset. \\
X_COMMENT & Additional information regarding coal bed X. \\
\hline
\end{tabular}

Table J2. Explanation of comments used to describe the northeast Texas drill-hole dataset (J.A. Luppens, U.S. Geological Survey, written commun., 2009).

\begin{tabular}{|c|c|}
\hline Symbol/Comment & Description \\
\hline- & $\begin{array}{l}\text { Notation is on the original coal exploration maps and is listed under the drill-hole name and elevation, } \\
\text { with no coal data recorded. No information about the definition of this notation is listed on any of } \\
\text { the Phillips coal exploration maps or drilling logs. The meaning of the notation is unknown. }\end{array}$ \\
\hline ? & Questionable data/information. \\
\hline+ & More coal than the amount that was recorded could be expected. \\
\hline$<$ & Less than. \\
\hline$>$ & Greater than. \\
\hline $\mathrm{b}$ & $\begin{array}{l}\text { Found at the end of a drill-hole name if the name had already been used for another location in the } \\
\text { dataset. This symbol was added after digitizing in order to give each drill hole a unique drill-hole } \\
\text { name. }\end{array}$ \\
\hline BAD LOG & Indicates a problem with the geophysical log instrument during exploration. \\
\hline BED DEPTH NOT RECORDED & No coal-bed depth information was recorded for this coal bed. \\
\hline BOTTOMED IN COAL & Terminated drilling in a coal bed. Coal extends deeper than the depth explored. \\
\hline $\mathrm{C}$ & $\begin{array}{l}\text { Found in the comment section of a coal bed, meaning carbonaceous. The coal bed was described to } \\
\text { contain a high ash content. }\end{array}$ \\
\hline C (after the drill-hole name) & Found at the end of the drill-hole name representing that the drill hole was cored. \\
\hline CADY & $\begin{array}{l}\text { This comment is written on the original coal exploration maps and the meaning is unknown. It could } \\
\text { be a misspelling of "CARBY”, which describes carbonaceous material. }\end{array}$ \\
\hline CARBY & Describing that the coal bed is "carbonaceous" and that it contains a high ash content. \\
\hline $\mathrm{CM}$ & Abbreviation for "carbonaceous material.” The coal was described to contain a high ash content. \\
\hline CORE SYMBOL & Triangle shaped drill-hole symbol meaning the drill hole was cored. \\
\hline CORED & Indicating that the drill hole was cored. \\
\hline
\end{tabular}


Table J2. Explanation of comments used to describe the northeast Texas drill-hole dataset (J.A. Luppens, U.S. Geological Survey, written commun., 2009). - Continued

\begin{tabular}{|c|c|}
\hline Symbol/Comment & Description \\
\hline $\mathrm{DH}$ & Abbreviation for “drill hole.” \\
\hline DO & $\begin{array}{l}\text { Abbreviation for "depth of oxidation.” The depth of the contact between weathered and unweathered } \\
\text { material. }\end{array}$ \\
\hline DUPLICATE DH & $\begin{array}{l}\text { Information on the original maps show two drill holes in two separate locations with the same data. It } \\
\text { is unclear which location is correct for the data listed. }\end{array}$ \\
\hline DUPLICATE DH NAME & The drill-hole name was used for two different locations on the original coal exploration maps. \\
\hline HOLE BOTTOMED IN LIGNITE & Drilling was terminated in lignite. Coal extends deeper than the depth explored. \\
\hline I & Abbreviation for "inferior." Subjective term used to describe poor coal quality. \\
\hline ILLEGIBLE DH NAME & The drill-hole name was not legible on the original coal exploration maps and may not be correct. \\
\hline NO DATA & No data were recorded on the original coal exploration maps for this drill hole. \\
\hline NO E-LOG & No geophysical logging was completed for this drill hole. \\
\hline NO LOG & No geophysical logging was completed for this drill hole. \\
\hline NP & Abbreviation for “not probed.” Geophysical logging never occurred at this location. \\
\hline NSL & $\begin{array}{l}\text { Abbreviation for "no significant lignite." Coal may have been found during exploration but because } \\
\text { the coal beds were thin (usually less than } 2 \text { feet. thick) no coal data were recorded. }\end{array}$ \\
\hline $\mathrm{OX}$ & Abbreviation for “oxidized” or “oxidation.” \\
\hline $\mathrm{P}$ & Abbreviation for “poor.” A subjective term used to describe a low-quality coal. \\
\hline Р ВОТТОМ & $\begin{array}{l}\text { The coal quality at the bottom of the coal bed was found to be poor. Coal quality in the bed decreased } \\
\text { with depth. }\end{array}$ \\
\hline RD (after the drill-hole name) & $\begin{array}{l}\text { Abbreviation for "re-drill." Was used when a location had to be re-explored either due to problems } \\
\text { with the first drill hole at the location or in some cases the location was re-drilled to explore deeper } \\
\text { strata. }\end{array}$ \\
\hline SAND & A layer of sand was encountered during exploration. \\
\hline TD IN COAL & Terminated drilling in a coal bed. Coal extends deeper than the depth explored. \\
\hline TRI & Abbreviation for "triangle." Signifies that the drill hole/coal bed was cored. \\
\hline TRIANGLE & Signifies that the drill hole/coal bed was cored. \\
\hline TWO DH NAMES & $\begin{array}{l}\text { Drill-hole location had two names. The first name listed was used as the drill-hole name and the sec- } \\
\text { ond name is listed in the comment section. }\end{array}$ \\
\hline VD & $\begin{array}{l}\text { Notation was written next to a coal bed on the original coal exploration maps. The meaning of the } \\
\text { comment is unknown. Could be a misspelling of "VP." }\end{array}$ \\
\hline VERY POOR & Subjective term used to describe coal of a very low quality. \\
\hline VP & Abbreviation for "very poor." Subjective term used to describe coal of a very low quality. \\
\hline
\end{tabular}


Table J2. Explanation of comments used to describe the northeast Texas drill-hole dataset (J.A. Luppens, U.S. Geological Survey, written commun., 2009). - Continued

\begin{tabular}{lc}
\hline \multicolumn{1}{c}{ Symbol/Comment } & Description \\
\hline VPW & Abbreviation for "very poor, weathered.” A subjective term used to describe coal of a poor quality that \\
has been altered by chemical or physical means. \\
Abbreviation for "weathered." Used to describe coal that has been altered by chemical or physical \\
means. \\
Used to describe coal that has been altered by chemical or physical means. \\
\hline
\end{tabular}

Table J3. Northeast Texas counties and the number of drill holes by county.

\begin{tabular}{|c|c|}
\hline County & Number of drill holes \\
\hline Bowie & 389 \\
\hline Camp & 15 \\
\hline Franklin & 205 \\
\hline Harrison & 1,207 \\
\hline Hopkins & 2,419 \\
\hline Marion & 94 \\
\hline Morris & 2 \\
\hline Panola & 535 \\
\hline Rains & 165 \\
\hline Red River & 69 \\
\hline Rusk & 1,676 \\
\hline Shelby & 102 \\
\hline Titus & 3 \\
\hline Upshur & 165 \\
\hline Van Zandt & 140 \\
\hline Wood & 824 \\
\hline Total & 8,010 \\
\hline
\end{tabular}



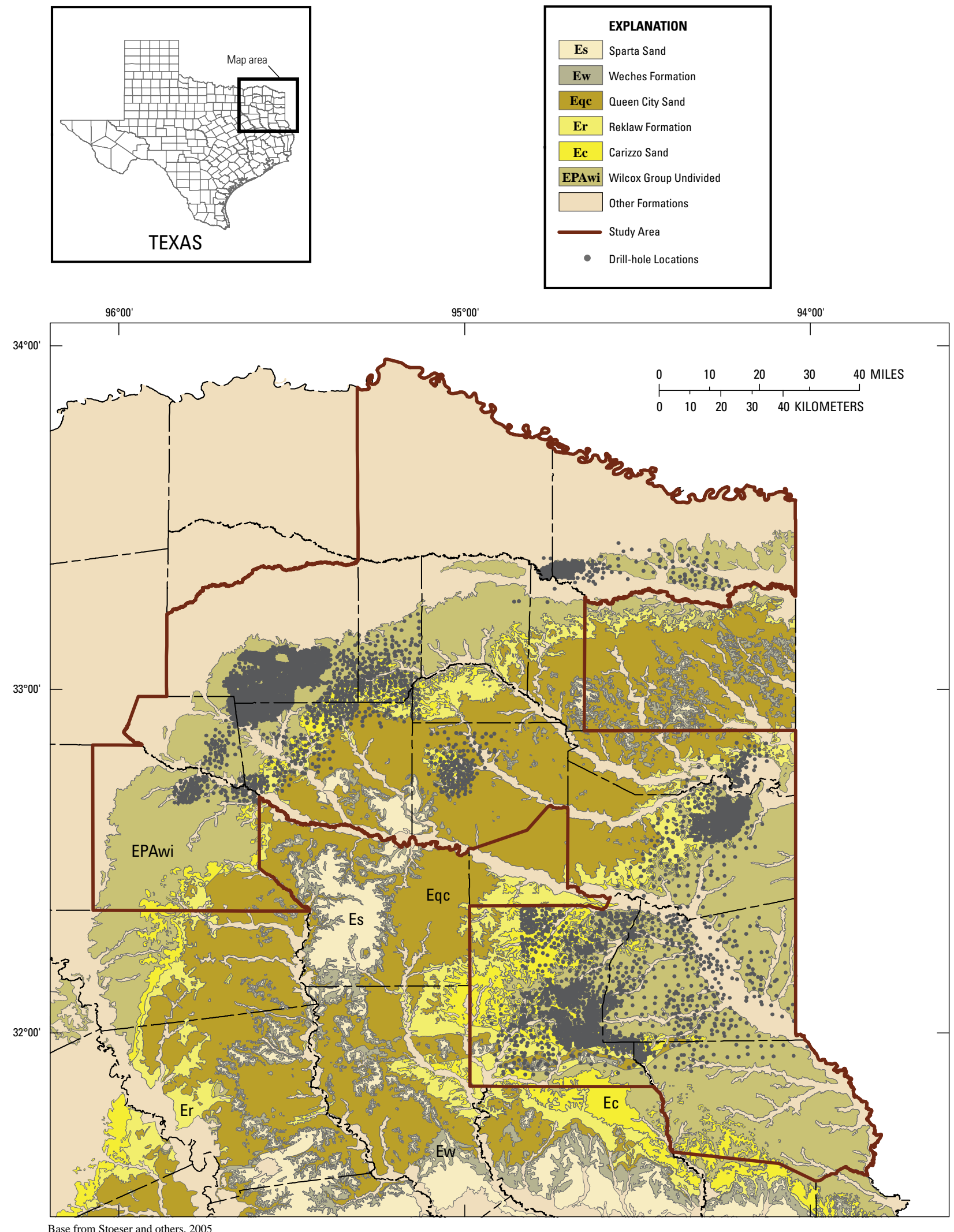

Figure J1. Geology of northeast Texas with drill-hole locations (Stoeser and others, 2005). 

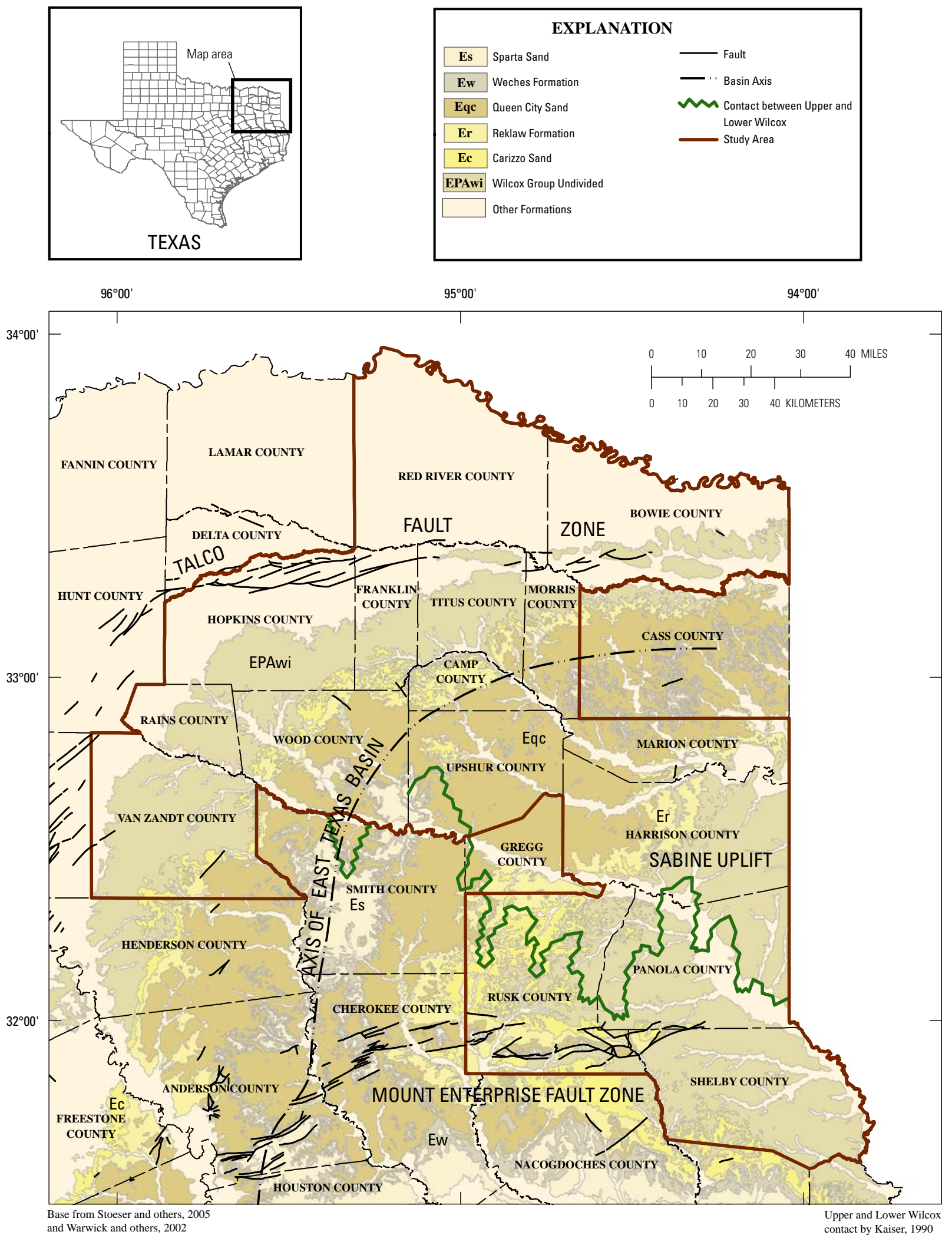

Figure J2. Geology and structure of northeast Texas (Kaiser, 1990; Stoeser and others, 2005; Warwick and others, 2002). 


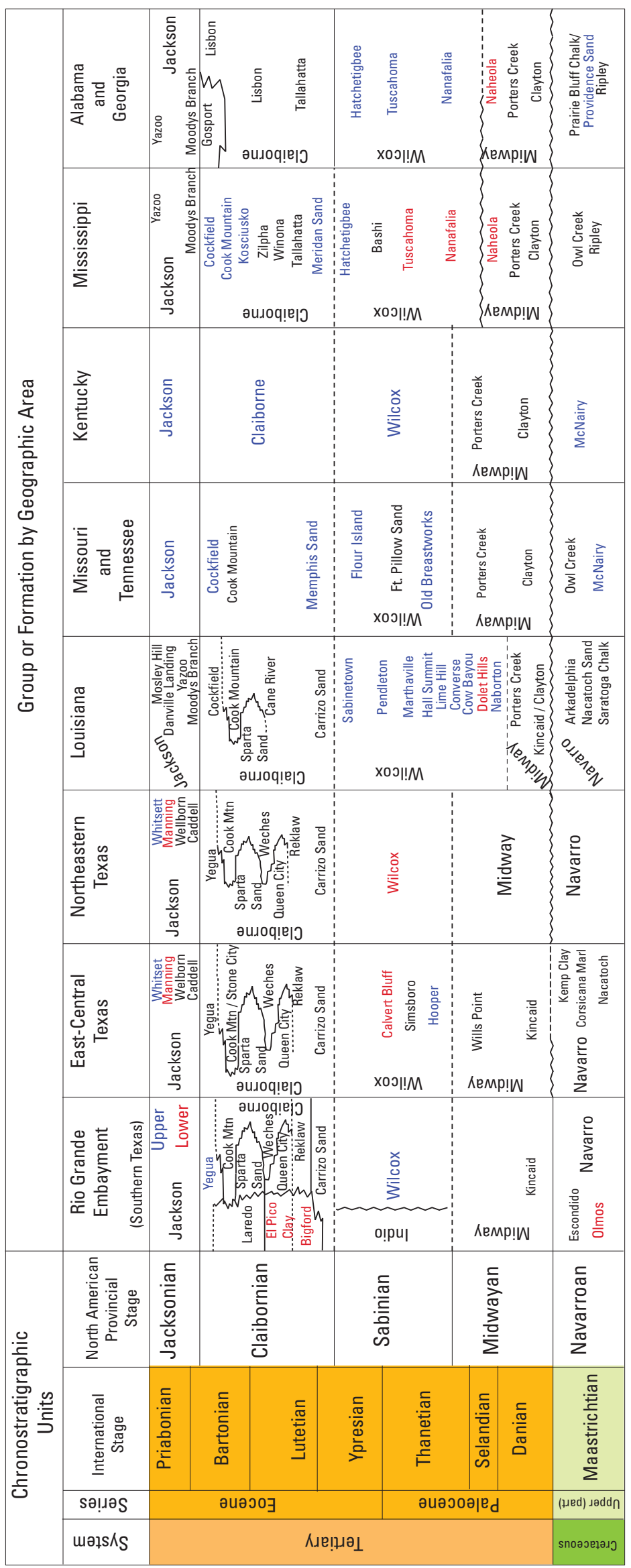

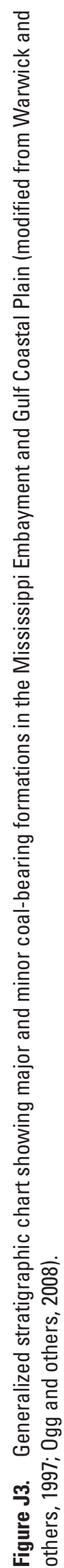




\section{Shallow Coal Exploration Drill-Hole Data, South and East-Central Texas}

By Brett J. Valentine, Matthew D. Merrill, Celeste D. Lohr, and Peter D. Warwick

Chapter K of

Shallow Coal Exploration Drill-Hole Data-Alabama, Georgia, Kentucky, Louisiana, Mississippi, Missouri, North Carolina, South Carolina, Tennessee, and Texas

Edited by Brett J. Valentine and Kristin O. Dennen

Open-File Report 2011-1261-K 
Suggested citation:

Valentine, B.J., Merrill, M.D., Lohr, C.D., and Warwick, P.D., 2012, Shallow coal exploration drill-hole data, south and east-central Texas, in Valentine, B.J., and Dennen, K.O., eds., Shallow coal exploration drill-hole data-Alabama, Georgia, Kentucky, Louisiana, Mississippi, Missouri, North Carolina, South Carolina, Tennessee, and Texas: U.S. Geological Survey Open-File Report 2011-1261, ch. K, 9 p. plus appendix. (Available online.) 


\section{Contents}

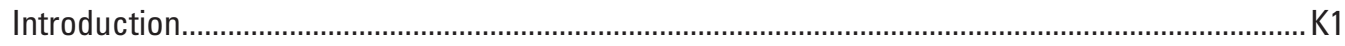

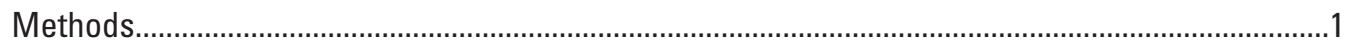

Generalized Coal Geology of South and East-Central Texas.....................................................

South Texas Coal Deposits..................................................................................................

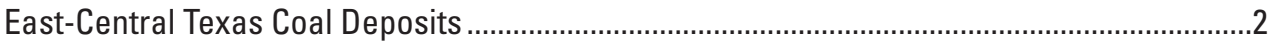

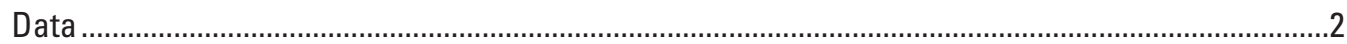

South Texas Coal Exploration Drill-Hole Dataset .....................................................................2

East-Central Texas Coal Exploration Drill-Hole Dataset.............................................................

References Cited..................................................................................................................

Appendix K1. Shallow Coal Exploration Drill-Hole Data for South Texas..........................................

Appendix K2. Shallow Coal Exploration Drill-Hole Data for East-Central Texas ...............................3

\section{Figures}

K1. Regional map of south Texas with county boundaries overlaid with drill-hole locations and major coal-bearing formations of the Gulf Coast Region .......................... K7

K2. Regional map of east-central Texas with county boundaries overlaid with drill-hole locations and major coal-bearing formations of the Gulf Coast Region ............8

K3. Generalized stratigraphic chart showing major and minor coal-bearing formations in the Mississippi Embayment and Gulf Coastal Plain ......................................

\section{Tables}

K1. Attribute titles and data descriptions and formats for the south and east-central Texas drill-hole datasets.

K2. Explanation of comments used to describe the south and east-central Texas drill-hole atasets.

K3. South Texas counties and the number of drill holes by county. .........................................

K4. East-central Texas counties and the number of drill holes by county...............................6 


\title{
Shallow Coal Exploration Drill-Hole Data, South and East- Central Texas
}

\author{
By Brett J. Valentine, Matthew D. Merrill, Celeste D. Lohr, and Peter D. Warwick
}

\section{Introduction}

Coal exploration drill-hole data from 3,825 wells in southern to east-central Texas drilled between 1975 and 1984 by Phillips Coal Company, a division of Phillips Petroleum Company (Phillips), are discussed in this chapter, and the data are provided in an accompanying spreadsheet. The data are part of a larger dataset donated to the U.S. Geological Survey (USGS) by the North American Coal Corporation, which purchased Phillips assets in 2001 (see chapter A, this volume). The data in 10 State reports have been digitized from field maps to create unified and spatially consistent coal exploration drill-hole datasets for each of the States included in the donation (chapters B-K, this volume). The drill-hole data for Texas have been divided into three coal exploration drill-hole datasets: northeast Texas, south Texas, and east-central Texas. Included in this report chapter are maps of major coal-bearing formations in south Texas and east-central Texas overlaid with drill-hole locations (figs. K1, K2), a list of data attributes and explanations of the data format (table K1), a list of comments found in the data and their descriptions (table K2), a list of counties and the number of drill holes for each county (tables K3, K4), and two electronic files in spreadsheet format with tabulated data for south Texas and east-central Texas (see appendixes K1 and K2). Information for northeast Texas can be found in chapter $\mathrm{J}$ of this open-file report.

\section{Methods}

Hardcopy Phillips exploration maps, in Texas central, south-central, and south 1927 State coordinate plane projection, were scanned and georeferenced into a geographic information system (GIS) using ArcMap ${ }^{\mathrm{TM}}$ software from the Environmental Systems Research Institute, Inc. (ESRI). Drillhole locations were then digitized in the GIS, and coal data were recorded in an attribute table (table K1) for each drillhole point. Each data point is uniquely labeled, first identifying the county with one or two letters followed by a numeral. The drill-hole name listed is the same name presented on the original maps. Alterations to the name occurred only when text was illegible on the original maps, or in the case of a duplicate drill-hole name the letter "b" was added after the number in the name. The attribute table for each point contains basic site information and location references along with information on the coal beds found during exploration (tables K1, K2). For example, drill-hole points where coal was found will have the beds numbered sequentially (for example: $1,2,3 \ldots 16$ ), followed by thickness of coal (1_C), thickness of coal and partings (1_CP), depth to the top of the bed (1_DEPTH), a bed regional name (1_BED), and any comments about quality or information in regard to the coal bed (1_COMMENTS). All of the depth and thickness measurements are measured in decimal feet. Comments have been added by USGS staff if there were problems or uncertainties during compiling or if any additional information on the maps needed to be described. Once the digitizing of the maps was complete, the spatial data were then reprojected into a North American Datum of 1983 geographic coordinate system in order to standardize all of the Phillips datasets into a common projection.

\section{Generalized Coal Geology of South and East-Central Texas}

\section{South Texas Coal Deposits}

The major coal-bearing formations in south Texas are found in sediments deposited during the Upper Cretaceous and the Tertiary (fig. K3). Upper Cretaceous coal-bearing strata of the Olmos Formation (Navarro Group) extend north out of the Sabinas Basin in Mexico and cross the Rio Grande at Eagle Pass, Texas, where the Olmos Formation's extent diminishes in the northeastern corner of Maverick County (fig. K1). The Olmos was deposited in a deltaic (fluvial dominated) depositional system (SanFilipo, 1999).

Coal-bearing formations of the Tertiary age in south Texas are found in the lower Wilcox, Claiborne, and Jackson Groups (fig. K3). Unlike the Olmos Formation, these Paleogene-aged formations can be found throughout the Gulf of Mexico Coastal Plain. While the majority of the coal resources in the Gulf of Mexico Coastal Plain are lignitic, 
coals of the Claiborne Group in south Texas are bituminous, blocky, and non-banded, resembling cannel and boghead coals of the bituminous coalfields of the Appalachian basin and Great Britain (Warwick and Hook, 1995). These coals formed in a transitional system between a marine-influenced, sandstone dominated, lower delta plain depositional environment and a more inland, mudstone, predominately freshwater deltaic environment (Warwick and Hook, 1995). Lignite deposits of the lower Wilcox Group and Jackson Group primarily formed in a barrier bar-strandplain depositional system, where clastic sediments were trapped as lagoonal muds up-dip of barrier bars (Kaiser, 1974).

\section{East-Central Texas Coal Deposits}

East-central Texas (fig. K2) is dominated with outcrops of Upper Cretaceous- and Tertiary-aged rocks with younger Quaternary sediments distributed along drainage systems of the Colorado, Brazos, and Trinity Rivers. The major coal-bearing formations within the region are found in the Wilcox, Claiborne, and Jackson Groups (see fig. K3). The Wilcox Group is divided into the Hooper, Simsboro, and Calvert Bluff Formations, which dip to the southeast increasing from $0.5^{\circ}$ to $2^{\circ}$, from northeast to southwest (Tewalt and others, 1983; Tewalt and Jackson, 1991). Coal-bearing strata of the Wilcox Group formed during progradation of a delta in the region during the late Paleocene and early Eocene. The Hooper Formation of the lower Wilcox is characterized by multi-stacked, upward coarsening sedimentary layers including discontinuous lignites that were deposited as interdistributary peats (Kaiser, 1974). Discontinuously overlying the Hooper Formation is the Simsboro Formation, a massive, cross-bedded, quartz and kaolinitic sand that displays typical fluvial sedimentary structures (Bammel, 1979). Deposition slowed in the lower Eocene, allowing an extensive accumulation of thick blanket peats, mainly of marsh (nonwoody) origin, to form at the contact between the Simsboro and the Calvert Bluffs Formations (fig. K3), with some coals containing woody material suggesting formation higher in the deltaic plain (Atlee and others, 1968; Kaiser, 1974). Most of the lignite of the Calvert Bluff Formation can be found at the contact with the Simsboro sands and within 200 feet of the overlying Carrizo Formation (middle Eocene Claiborne Group), but secondary occurrences are scattered irregularly throughout (Johnston and Jobling, 1979; Ayers and Kaiser, 1987).

The late Eocene-aged lignite-bearing intervals of the Yegua Formation (Claiborne Group) and the Manning Formation (Jackson Group) formed during transgressiveregressive cycles of deposition, with each cycle containing sediments from multiple environments (Yancey, 1997). Yancey (1997) characterized the Yegua-Jackson lignites to be part of a strand plain system, where peat was deposited near the marine shoreline, and was preserved as the shoreline migrated over the accumulated organic material.

\section{Data}

\section{South Texas Coal Exploration Drill-Hole Dataset}

The south Texas drill-hole dataset contains coal exploration information for 980 drill-hole locations within eight counties in the Gulf Coast region (fig. K1, table K3). Geophysical instruments were used on 939 drill holes and had an average depth of 254 feet, with a maximum depth of 367 feet. The 41 drill holes that did not have any probe depth information were assigned a depth of 0 within the attribute table. The area that has the densest coverage with 694 drill holes is along the margin of Upper Cretaceous- and Paleocene-aged sediments, extending from Eagle Pass to Bexar County, Texas (fig. K1). The remainder of the data (286 drill holes), explores Oligocene- to Eocene-aged sediments located along the Rio Grande from Webb County to Starr County, Texas. Due to the generalized nature of the original highway maps that contained the drill-hole information and the process of georeferencing these maps to a new base layer, we expect the location error to be \pm 0.25 mile.

\section{East-Central Texas Coal Exploration Drill-Hole Dataset}

The east-central Texas drill-hole dataset contains coal exploration information for 2,845 drill-hole locations within 17 counties in the Gulf Coast region (fig. K2, table K4). Geophysical instruments were used on 2,273 drill holes and had an average probe depth of 228 feet, with a maximum depth of 944 feet. The 572 drill-hole points that did not have a recorded probe depth were given a value of 0 within the attribute table. The drill-hole locations are concentrated in areas along the Wilcox and lower Claiborne Formation boundaries shown in figure K2, between Bastrop to Henderson Counties, and along the Upper Claiborne and Jackson Formation boundaries shown in figure K2, between Fayette and Trinity Counties. Due to the generalized nature of the original highway maps that contained the drill-hole information and the process of georeferencing these maps to a new base layer, we expect the location error to be \pm 0.25 mile.

\section{References Cited}

Atlee, W.A., Elsik, W.C., Frazier, D.E., and Zingula, R.P., Field Committee, 1968, Environments of deposition, Wilcox Group, Texas Gulf Coast: Houston Geological Society, Field Trip Guidebook, 43 p. 
Ayers, W.B., and Kaiser, W.R., 1987, Regional depositional settings, resources, and quality of lignite in the Wilcox Group of east Texas and the Jackson Group of east and south Texas, in Finkelman, R.B., Casagrande, D.J., and Benson, S.A., eds., Gulf Coast lignite geology, Prepared for the fourteenth Biennial Lignite Symposium on the Technology and Utilization of Low-Rank Coals: Environmental and Coal Associates, Reston, Va., p. 83-128.

Bammel, B.H., 1979, Stratigraphy of the Simsboro Formation, east-central Texas: Baylor Geological Studies, Baylor University, Bulletin No. 37, 40 p.

Johnston, J.E., and Jobling, J.L., 1979, Lignite resources in east-central Texas: American Association of Petroleum Geologists, Society of Economic Paleontologists and Mineralogists Convention, 1979, Houston Geological Society, Field Trip Guidebook, 15 p.

Kaiser, W.R., 1974, Texas lignite-Near-surface and deepbasin resources: Bureau of Economic Geology, University of Texas at Austin, Report of Investigations No. 79, 70 p.

Ogg, J.G., Ogg, Gabi, and Gradstein, F.M., 2008, The concise geologic time scale: Cambridge, U.K., Cambridge University Press, 184 p.

SanFilipo, J.R., 1999, Some speculations on coal-rank anomalies of the South Texas Gulf Province and adjacent areas of Mexico and their impact on coal-bed methane and source rock potential 1999 CBM Gulf Coast Region Coal, in Warwick, P.D., Aubourg, C.E., and Willett, J.C., eds., Tertiary coals in south Texas-Anomalous cannel-like coals of Webb County (Claiborne Group, Eocene) and lignites of Atascosa County (Jackson Group, Eocene); geologic setting, character, source-rock and coal-bed methane potential: U.S. Geological Survey Open-File Report 99-301, p. 37-47.

Tewalt, S.J., Bauer, M.A., Mathew, D., Roberts, M.P., Ayers, W.B., Jr., Barnes, J.W., and Kaiser, W.R., 1983, Estimation of coal resources in Texas Gulf Coast, Ohio Northern Appalachian, and Wyoming Powder River Basins-A comparison of statistical approaches: Bureau of Economic Geology, University of Texas at Austin, Report of Investigations No. 136, 137 p.
Tewalt, S.J., and Jackson, M.L.W, 1991, Estimation of lignite resources in the Wilcox Group of central and east Texas using the National Coal Resources Data System: Bureau of Economic Geology, University of Texas at Austin, Geological Circular 91-1, 44 p.

Warwick, P.D., and Hook, R.W., 1995, Petrography, geochemistry, and depositional setting of the San Pedro and Santo Thomas coal zones-Anomalous algae-rich coals in the middle part of the Claiborne Group (Eocene) of Webb County, Texas: International Journal of Coal Geology, v. 28, p. 303-342.

Warwick, P.D., SanFilipo, J.R., Crowley, S.S., Thomas, R.E., and Freid, J., comps., and Tully, J.K., digital comp., 1997, Map showing outcrop of the coal-bearing units and land use in the Gulf Coast coal region: U.S. Geological Survey Open-File Report 97-172, 1 sheet, accessed April 20, 2011, at http://pubs.usgs.gov/of/1997/of97-172/.

Yancey, T.E., 1997, Depositional environments of Late Eocene lignite-bearing strata, east-central Texas: International Journal of Coal Geology, v. 34, p. 261-275.

\section{Appendix K1}

The south Texas coal exploration drill-hole dataset in spreadsheet format is available at pubs.usgs.gov/of/2011/1261/ Appendices/K1-STX.xls.

\section{Appendix K2}

The east-central coal exploration drill-hole dataset in spreadsheet format is available at pubs.usgs.gov/of/2011/1261/ Appendices/K2-ECTX.xls. 
Table K1. Attribute titles and data descriptions and formats for the south and east-central Texas drill-hole datasets.

\begin{tabular}{ll}
\hline \multicolumn{1}{c}{ Attribute title } & \multicolumn{1}{c}{ Data description and format } \\
\hline DRILL-HOLE NAME & $\begin{array}{l}\text { County code followed by drill-hole number. In some cases a county may have both a one-letter and two- } \\
\text { letter code for drill-hole names. } \\
\text { County where the drill hole is located. } \\
\text { COUNTY }\end{array}$ \\
Elevation above sea level in feet. \\
DEPTH_TOTAL & Depth of drill hole in feet. \\
DEPTH_PROBED & Depth of geophysical probe measurement in feet. \\
LATITUDE & Decimal degree location values given to 4 decimal places. \\
LONGITUDE & Decimal degree location values given to 4 decimal places. \\
COMMENT & Additional information regarding the entire drill hole. \\
X_C & Thickness of coal for bed number X in decimal feet. \\
X_CP & Thickness of coal and partings combined for bed number X in decimal feet. \\
X_DEPTH & Top depth of bed number X in feet. \\
X_BED & Coal bed regional name for coal bed X. \\
X_COMMENT & Additional information regarding coal bed X. \\
\hline
\end{tabular}

Table K2. Explanation of comments used to describe the south and east-central Texas drill-hole datasets (modified from J.A. Luppens, U.S. Geological Survey, written commun., 2009).-Continued

\begin{tabular}{|c|c|}
\hline Symbol/Comment & Description \\
\hline- & $\begin{array}{l}\text { Notation is on the original coal exploration maps and is listed under the drill-hole name and elevation, } \\
\text { with no coal data recorded. No information about the definition of this notation is listed on any of the } \\
\text { Phillips coal exploration maps or drilling logs. The meaning of the notation is unknown. }\end{array}$ \\
\hline “A”? & $\begin{array}{l}\text { The letter "A" was written next to the surface elevation on the original maps. May be related to the oc- } \\
\text { currence of a geologic formation or a specific coal bed. }\end{array}$ \\
\hline “B”? & $\begin{array}{l}\text { The letter "B" was written next to the surface elevation on the original maps. May be related to the occur- } \\
\text { rence of a geologic formation or a specific coal bed. }\end{array}$ \\
\hline ? & Questionable data/information. \\
\hline+ & More coal than the amount that was recorded could be expected. \\
\hline$>$ & Greater than. \\
\hline $\mathrm{b}$ & $\begin{array}{l}\text { Found at the end of a drill-hole name if the name had already been used for another location in the data- } \\
\text { set. This symbol was added after digitizing in order to give each drill hole a unique drill-hole name. }\end{array}$ \\
\hline BLANK COAL & No data were recorded on the original maps for this location. \\
\hline C (After the drill-hole name) & Found at the end of the drill-hole name representing that the drill hole was cored. \\
\hline CARB ZONE & Describing that the coal bed is "carbonaceous" and that it contains a high ash content. \\
\hline CARBY & Describing that the coal bed is “carbonaceous” and that it contains a high ash content. \\
\hline $\mathrm{CM}$ & Abbreviation for "carbonaceous material.” The coal was described to contain a high ash content. \\
\hline CORED & Indicating that the drill hole was cored. \\
\hline $\mathrm{DH}$ & Abbreviation for “drill hole.” \\
\hline DUPLICATE DH NAME & The drill-hole name was used for two different locations on the original coal exploration maps. \\
\hline
\end{tabular}


Table K2. Explanation of comments used to describe the south and east-central Texas drill-hole datasets (modified from J.A. Luppens, U.S. Geological Survey, written commun., 2009).—Continued

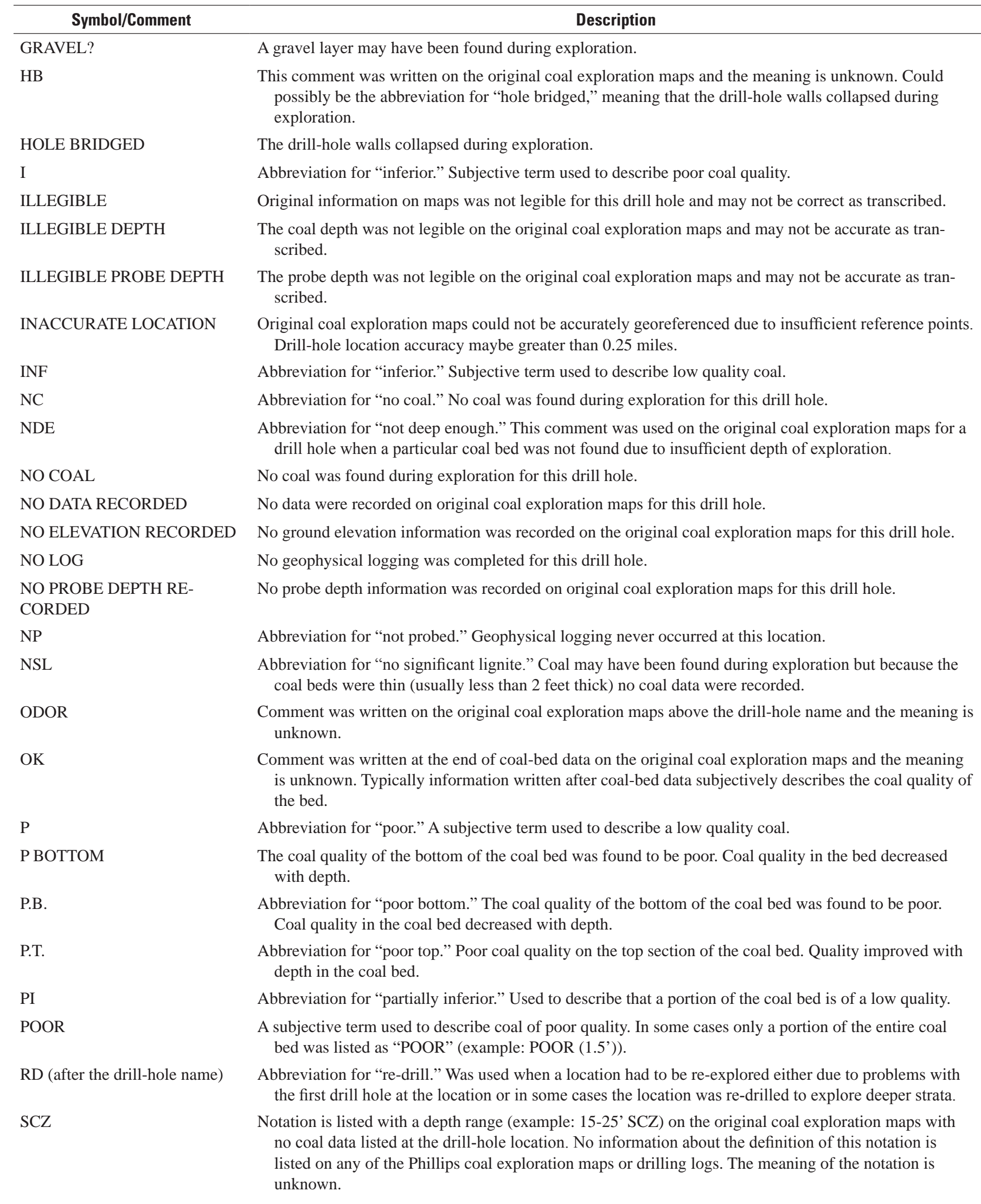


Table K2. Explanation of comments used to describe the south and east-central Texas drill-hole datasets (modified from J.A. Luppens, U.S. Geological Survey, written commun., 2009).—Continued

\begin{tabular}{ll}
\hline \multicolumn{1}{c}{ Symbol/Comment } & \multicolumn{1}{c}{ Description } \\
\hline SL & Abbreviation for "silt.” A layer of silt was encountered during exploration. \\
TD IN COAL & Terminated drilling in a coal bed. Coal extends deeper than the depth explored. \\
TRI & Abbreviation for "triangle." Signifies that the drill-hole/coal bed was cored during exploration. \\
TRIANGLES & Signifies that multiple coal beds were cored during exploration. \\
V. INF & Abbreviation for "very inferior.” Subjective term used to describe coal of a very low quality. \\
VP & Abbreviation for "very poor." Subjective term used to describe coal of a very low quality. \\
WASHOUT & Occurs when a loose layer of material is eroded in the bore hole and the well diameter is enlarged. \\
WEATHERED & Used to describe coal that has been altered by chemical or physical means. \\
WSOUT & Abbreviation for "washout.” Occurs when a loose layer of material is eroded in the bore hole and the well \\
& diameter is enlarged. \\
\hline
\end{tabular}

Table K3. South Texas counties and the number of drill holes by county.

\begin{tabular}{lc}
\hline \multicolumn{1}{c}{ County } & Number of drill holes \\
\hline Atascosa & 32 \\
Bexar & 39 \\
Maverick & 208 \\
Medina & 374 \\
Starr & 35 \\
Uvalde & 41 \\
Webb & 167 \\
Zapata & 84 \\
\hline Total & 980 \\
\hline
\end{tabular}

Table K4. East-central Texas counties and the number of drill holes by county.

\begin{tabular}{|c|c|}
\hline County & Number of drill holes \\
\hline Anderson & 4 \\
\hline Bastrop & 160 \\
\hline Brazos & 2 \\
\hline Burleson & 334 \\
\hline Falls & 7 \\
\hline Fayette & 258 \\
\hline Freestone & 591 \\
\hline Henderson & 38 \\
\hline Houston & 65 \\
\hline Lee & 305 \\
\hline Leon & 4 \\
\hline Limestone & 629 \\
\hline Milam & 175 \\
\hline Polk & 4 \\
\hline Trinity & 88 \\
\hline Walker & 48 \\
\hline Washington & 133 \\
\hline Total & 2,845 \\
\hline
\end{tabular}



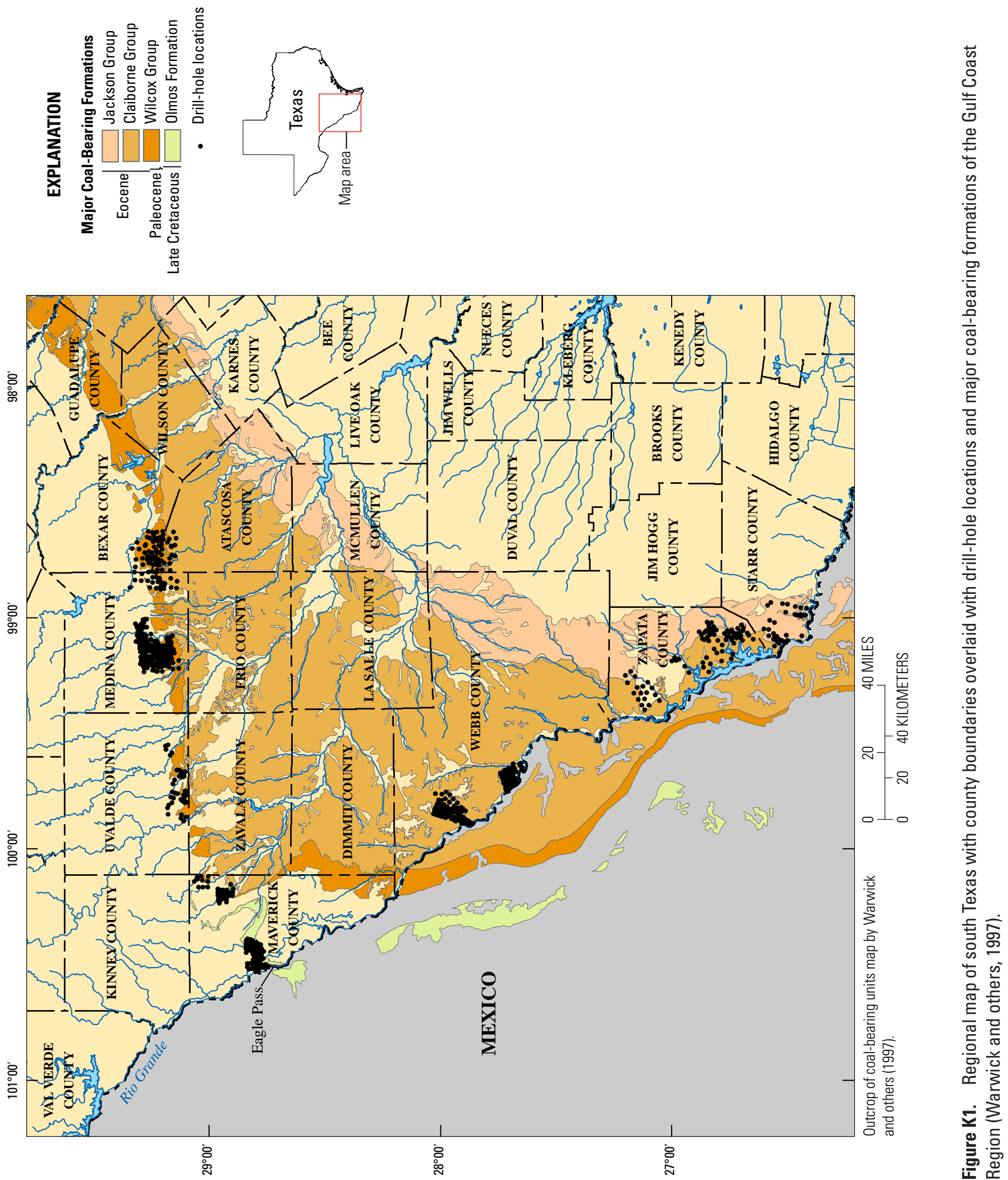

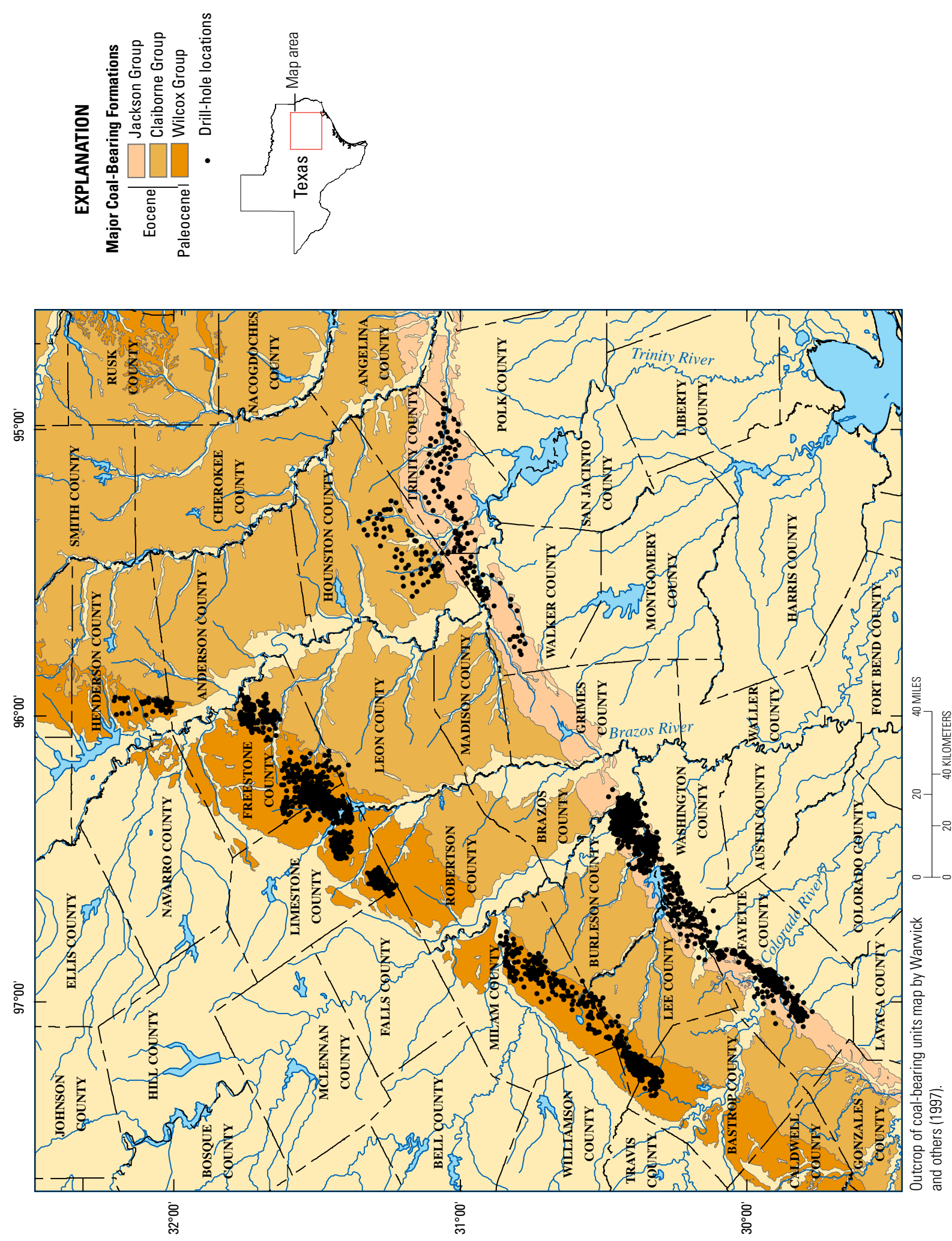

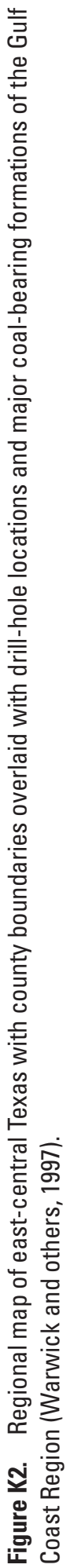



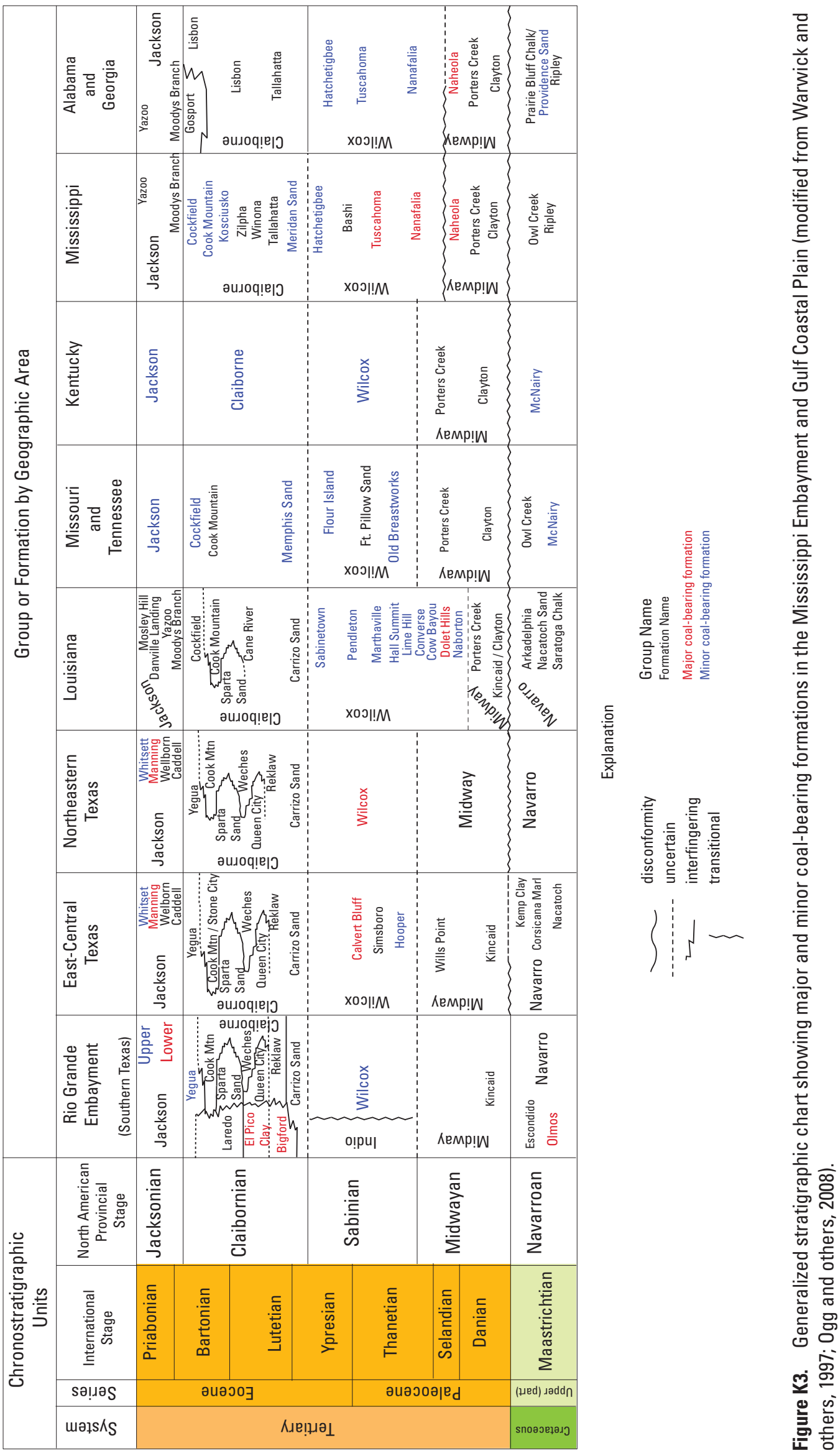
